"Efeito do lactato de cálcio aplicado previamente ao dentifrício fluoretado na desmineralização do esmalte bovino e na composição da placa bacteriana formada in situ"

TATI ANA DE ALMEI DA FURLANI

Dissertação apresentada à Faculdade de Odontologia de Bauru, da Universidade de São Paulo, como parte dos requisitos para obtenção do título de Mestre em Odontologia, área de Biologia Oral.

\title{
BAURU
}

2007 


\section{"Efeito do lactato de cálcio aplicado previamente ao dentifrício fluoretado na desmineralização do esmalte bovino e na composição da placa bacteriana formada in situ"}

TATIANA DE ALMEIDA FURLANI

Dissertação apresentada à Faculdade de Odontologia de Bauru, da Universidade de São Paulo, como parte dos requisitos para obtenção do título de Mestre em Odontologia, área de Biologia Oral.

Orientadora: Profa. Dra. Marília Afonso Rabelo Buzalaf

BAURU

2007 


\begin{tabular}{|c|}
\hline Furlani, Tatiana de Almeida \\
Efeito do lactato de cálcio aplicado previamente ao \\
dentifrício fluoretado na desmineralização do esmalte bovino e \\
na composição da placa bacteriana formada in situ. - Bauru, \\
2007. \\
$159 p$; il.; 30cm \\
Dissertação (Mestrado) - Faculdade de Odontologia de \\
Bauru. USP \\
Orientadora: Prof ${ }^{a}$. Dra . Marília Afonso Rabelo Buzalaf
\end{tabular}

Autorizo, exclusivamente para fins acadêmicos e científicos, a
reprodução total ou parcial desta dissertação, por processos
fotocopiadores elou meios eletrônicos.
Assinatura do autor:
Data:

Comitê de Ética da FOB: $\quad$ Projeto de pesquisa aprovado em 02 de abril de 2004

$N^{0}$ de Protocolo: 05/2004 


\section{Dados Curriculares}

TATIANA DE ALMEIDA FURLANI

Nascimento

Naturalidade

Filiação

$1998-2001$

$2000-2001$

$2003-2004$

Associações
02 de abril de 1976

Campinas - SP

Itagiba Furlani

Rosa de Almeida Furlani

Curso de graduação em Licenciatura Plena em Ciências Biológicas - Universidade Estadual Paulista

Desenvolvimento de projeto de Iniciação Científica, com auxílio da Fundação de Amparo à Pesquisa do Estado de São Paulo

Professora substituta da Disciplina de Biologia e Ciências do Ensino Fundamental e Médio da Rede Estadual de Ensino de Bauru - SP

SBPqO - Sociedade Brasileira de Pesquisa Odontológica 
"Todo homem, por natureza, quer saber."

Aristóteles

"O começo é a parte mais importante do trabalho." Platão

"Um bom começo é a metade." Aristóteles 


\section{Dedicatória}

Aos meus queridos pais, Itagiba e Rosa (in memoriam)

Aos meus irmãos, Marígia, Cássia e José Reynaldo

Aos meus cunhados, Rodrigo e Márcia

Aos meus sobrinhos, Pedro Henrique, Bruna, Roberta e

Fernanda

Amigas, Kátia, Maria Vicentina, Flávia e Cláudia

Este trabalho só se tornou possível porque tenho ao meu lado, amparando-me, fortalecendo-me, pessoas maravilhosas.

Se, nestes anos de convivência eu me esqueci de dizer, digo agora:

Amo-os de todo o meu coração! 


\section{Agradecimentos Especiais}

Deus, eu vos agradeço, Senhor, por me conceder a vida e por tudo que conquistei até hoje.

À professora Dra. Marília Afonso Rabelo Buzalaf, por mais esta orientação repleta de ensinamentos e amizade. Ao seu lado, fui aprendendo, não apenas as técnicas, instrumentos da pesquisa, mas a "fazer ciência", com a aptidão de que é detentora. Este trabalho é para mim, mais um fruto deste aprendizado. Muito obrigada!

Às doutorandas Ana Carolina Magalhães e Flávia de Moraes Italiani, por toda ajuda, de fato tão necessária para o desenvolvimento deste trabalho. Pela paciência em me mostrar os caminhos certos, serem objetivas e organizadas. Muito obrigada!

Meus sinceros agradecimentos aos voluntários que participaram dessa pesquisa, Aline, Ana Carolina, Cláudia,

Flávia, Flávia Negreiros, Heloísa, Lívia Comar, Mileni e Thiemi, pela paciência, senso de cooperação, desprendimento e dedicação. 


\section{Agradecimentos}

À Faculdade de Odontologia de Bauru - USP, na pessoa de seu diretor, Prof. Dr. Luiz Fernando Pegoraro, pela oportunidade em realizar o curso de Mestrado.

Aos professores do Departamento de Ciências Biológicas da

Faculdade de Odontologia de Bauru, Ana Paula Campanelli, Antonio de Castro Rodrigues, Carlos Ferreira dos Santos, Eulázio Mikio Taga, Flávio Augusto Cardoso de Faria, Gerson Francisco de Assis, Marília Afonso Rabelo Buzalaf, Rodrigo Cardoso de Oliveira e Rumio Taga.

A todos os professores do curso de Pós-Graduação em Biologia Oral da Faculdade de Odontologia de Bauru - USP, pelos ensinamentos.

Ao Prof. Dr. Alberto Carlos Botazzo Delbem, por ser sempre tão solícito.

Aos funcionários da Bioquímica: Ovídio, Thelma e Flávia, sempre dispostos a ajudar.

Aos funcionários do Laboratório de Materiais Dentários: Alcides e Sandrinha, sempre muito receptivos. 
Aos amigos Adriano Hoshi, Marina Calvo Fracasso, Daniela Rios e Heitor Honório, por sanarem todas as minhas dúvidas durante as etapas laboratoriais.

Aos amigos do laboratório Aline, Andréa Gutierrez, Esther, Flávia Levy, Heloísa, Juliano Pessan, Maria Heloísa, Rejane e Thiemi pelo convívio tão amigável.

Aos colegas do mestrado em Biologia Oral Adriana, Claudinha, Eduardo, Élide, Flavinha, Marcela, Nicolas, Valéria.

Aos colegas do Doutorado em Biologia Oral Juliane, Fabiano, Tatiana Salles, Tânia, Thaís e Sílvia.

Aos funcionários da biblioteca da FOB- USP, pela prontidão na realização dos inúmeros xerox de artigos.

À FAPESP, por mais este indispensável apoio financeiro que possibilitou o meu aprimoramento acadêmico e também o desenvolvimento deste trabalho.

Àqueles que não mencionei, mas, que de alguma forma, colaboraram com a realização deste trabalho e com meu desenvolvimento científico e pessoal. 


\section{Sumário}

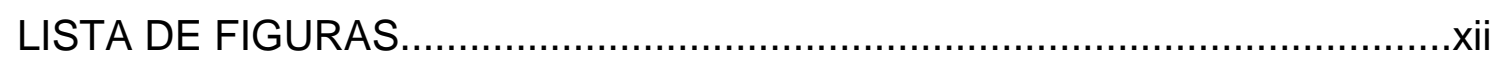

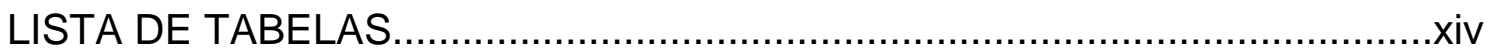

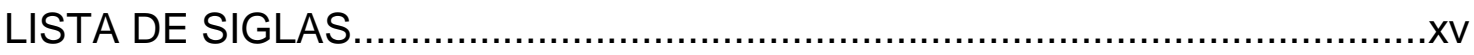

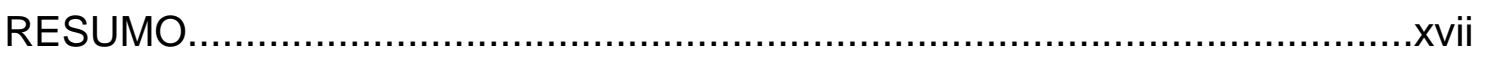

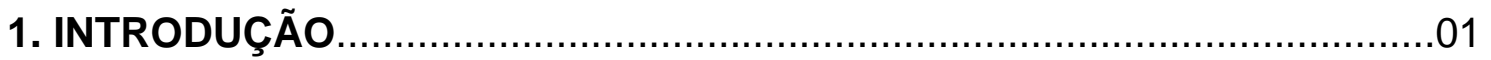

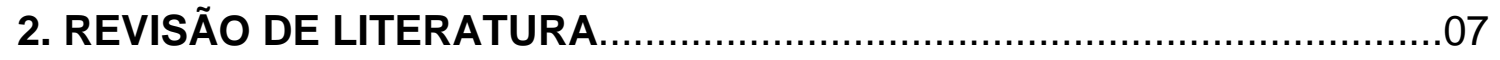

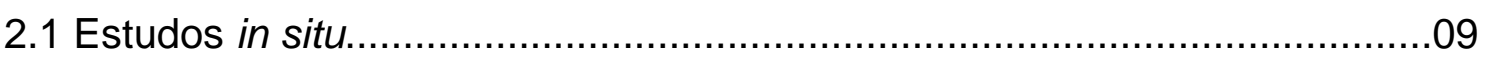

2.2 Avaliação da perda mineral......................................................21

2.3 Concentração de íons na placa bacteriana............................................30

2.4 Efeito da sacarose sobre a placa bacteriana...........................................34

2.5 Efeito do bochecho de Ca no esmalte e na placa bacteriana...................39

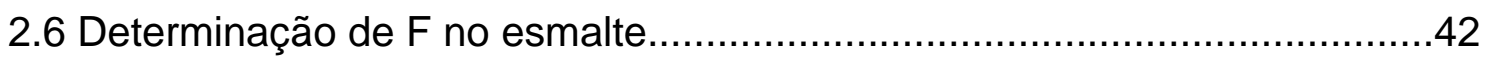

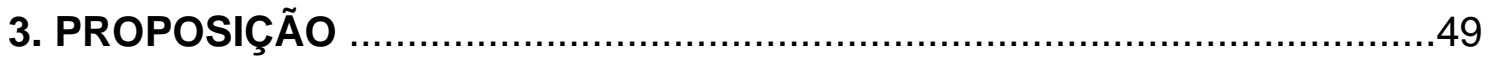

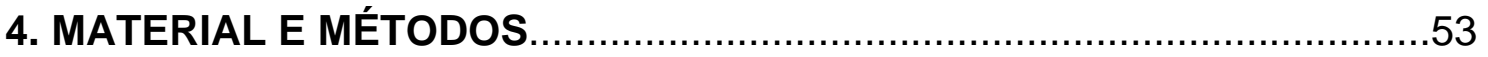

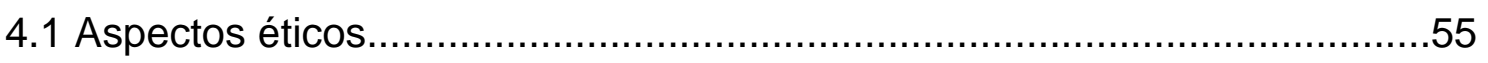

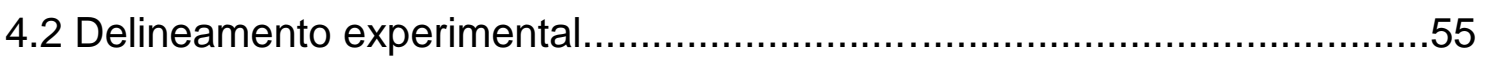

4.3 Seleção dos voluntários........................................................59

4.4 Preparo dos blocos de esmalte bovino................................................59 
4.4.1 Obtenção dos dentes e preparo dos blocos de esmalte bovino....59

4.4.2 Desgaste e polimento dos blocos de esmalte bovino .63

4.5 Avaliação da microdureza superficial inicial....................................69

4.6 Indução da lesão de cárie in vitro...................................................... 71

4.7 Avaliação da microdureza superficial após a desmineralização................73

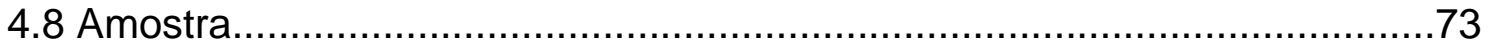

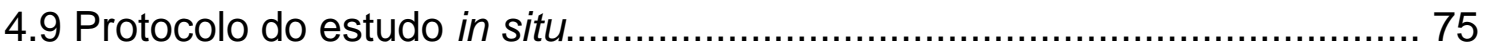

4.10 Análise de cálcio e flúor da placa bacteriana....................................81

4.11 Limpeza e secção dos espécimes............................................. 89

4.12 Análise da microdureza superficial final e interna.............................89

4.13 Análise da concentração do flúor fracamente ligado.............................91

4.14 Análise Estatística ....................................................................95

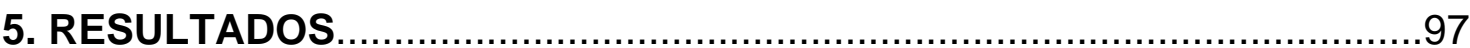

6. DISCUSSÃO

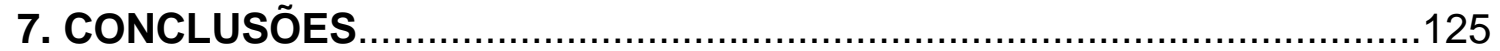

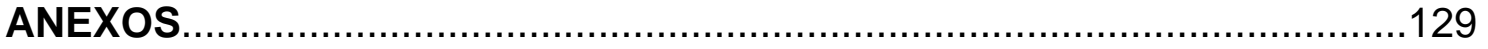

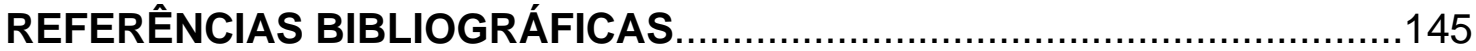

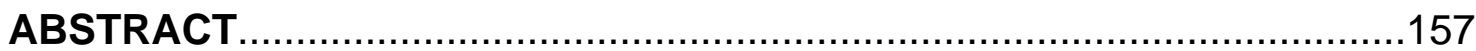




\section{Lista de Figuras}

FIGURA 1 - a. esquema proposto para a retenção de $\mathrm{F}$ à parede bacteriana, mediada por íons $\mathrm{Ca}$; b. retirada do $\mathrm{F}$ e liberação para o meio bucal

FIGURA 2 - Fluxorama do delineamento experimental 57

FIGURA 3 - Secção para separar coroa da raiz 61

FIGURA 4 - Fixação da coroa para corte $\quad 61$

FIGURA 5 - a. máquina de cortes; b. espécime posicionado para corte 63

FIGURA 6 - a. secções duplas no sentido mésio-distal e cérvico-incisal; b. espécime obtido da região central 63

$\begin{array}{ll}\text { FIGURA } 7 \text { - Politriz metalográfica } & 67\end{array}$

FIGURA 8 - Blocos antes e após planificação da dentina 67

$\begin{array}{ll}\text { FIGURA } 9 \text { - Aparelho de ultra-som } & 67\end{array}$

FIGURA 10 - Bloco após polimento do esmalte 67

FIGURA 11 - Microdurômetro acoplado ao computador 69

FIGURA 12 - Ponta apalpadora tipo Knoop 69

$\begin{array}{ll}\text { FIGURA } 13 \text { - Indentação delimitada para cálculo da microdureza } & 71\end{array}$

FIGURA 14 - Bloco selado com esmalte de unha 73

FIGURA 15 - Blocos imersos na solução de des 73

$\begin{array}{ll}\text { FIGURA } 16 \text { - Descrição das } 4 \text { fases experimentais } & 75\end{array}$

FIGURA 17 - Kit entregue a cada voluntário $\quad 77$ 
FIGURA 18 - Instalação do dispositivo palatino

FIGURA 19 - Gotejamento da solução de sacarose a $20 \%$ sobre os blocos de esmalte

FIGURA 20 - Solução de cálcio usada para bochecho

FIGURA 21 - Gotejamento da solução de dentifrício sobre os blocos de esmalte 81

FIGURA 22 - a. retirada da tela com bisturi; b. placa bacteriana coletada com espátula plástica

FIGURA 23 - a. placa bacteriana nos tubos de microcentrífuga; b. adição de $\mathrm{HCl}$ 0,5 M; c. agitação em agitor de tubos; d. agitação em mesa agitora por $3 \mathrm{~h}$

FIGURA 24 - Eletrodo íon específico combinado e analisador de íons Orion

FIGURA 25 - a. embutidora de espécimes; b. espécimes embutidos em resina acrílica

FIGURA 26 - Bloco preparado para realização da biopsia

FIGURA 27 - Regra de três para o cálculo da massa a ser diluída em água deionizada para se obter a Molaridade

FIGURA 28 - a. espécime imerso em $0,3 \mathrm{~mL}$ de $\mathrm{KOH} 1 \mathrm{M}$; b. espécime sendo neutralizado com $0,3 \mathrm{~mL}$ de TISAB II

FIGURA 29 - Média da \% volume mineral nas diferentes profundidades para o esmalte hígido

FIGURA 30 - Média da \% volume mineral nas diferentes profundidades para o esmalte com lesão artificial de cárie 


\section{Lista de Tabelas}

Tabela 1 - Reagentes utilizados para o preparo de $1 \mathrm{~L}$ de solução para formação de cárie artificial

Tabela 2 - Concentrações médias $( \pm E P)$ de cálcio e flúor presentes na placa dentária sobre o esmalte hígido $(\mathrm{H})$ e com lesão artificial de cárie (L), após tratamento com bochecho de lactato de cálcio $150 \mathrm{mM}$ ou água deionizada (placebo), seguido pelo uso de dentifrício com (1100 ppm) ou sem flúor

Tabela 3 - Concentração média ( $\pm E P$ ) de flúor e \%SMHC média $( \pm D P)$ no esmalte hígido $(H)$ e com lesão artificial de cárie (L), após tratamento com bochecho de lactato de cálcio $150 \mathrm{mM}$ ou água deionizada (placebo), seguido pelo uso de dentifrício com (1100 ppm) ou sem flúor

Tabela 4 - Valores do conteúdo mineral (média, \pm DP) para o esmalte hígido $(\mathrm{H})$, após tratamento com bochecho de lactato de cálcio $150 \mathrm{mM}$ ou água deionizada (placebo), seguido pelo uso de dentifrício com (1100 ppm) ou sem flúor.

Tabela 5 - Valores do conteúdo mineral (média, \pm DP) para o esmalte com lesão artificial de cárie (L), após tratamento com bochecho de lactato de cálcio $150 \mathrm{mM}$ ou água deionizada (placebo), seguido pelo uso de dentifrício com (1100 ppm) ou sem flúor 


\section{Lista de Abreviaturas e Símbolos}

\begin{tabular}{|c|c|}
\hline AmF & fluoreto de amônio \\
\hline $\mathrm{Ca}$ & elemento cálcio \\
\hline $\mathrm{Ca}^{2+}$ & íon cálcio \\
\hline $\mathrm{CaF}_{2}$ & fluoreto de cálcio \\
\hline \multirow[t]{2}{*}{$\mathrm{CaF}_{2}$-like } & fluoreto de cálcio-like \\
\hline & (sal de estrutura semelhante ao fluoreto de cálcio) \\
\hline $\mathrm{cm}$ & centímetro \\
\hline $\mathrm{cm}^{2}$ & centímetro quadrado \\
\hline et al. & e colaboradores \\
\hline FFA & flúor fosfato acidulado \\
\hline $\mathrm{F}$ & elemento flúor \\
\hline$F^{-}$ & íon fluoreto \\
\hline$g$ & grama \\
\hline $\mathrm{HCl}$ & ácido clorídrico \\
\hline $\mathrm{HClO}_{4}$ & ácido perclórico \\
\hline HMDS & hexametil-disiloxano \\
\hline in situ & (latim) - em sítio, no local (no caso, a cavidade bucal) \\
\hline in vitro & (latim) - em laboratório \\
\hline in vivo & (latim) - no ser humano \\
\hline $\mathrm{KCl}$ & cloreto de potássio \\
\hline $\mathrm{KHN}$ & Knoop hardness number (número de dureza Knoop) \\
\hline $\mathrm{KHz}$ & quilo hertz \\
\hline M & molar (mol/L) \\
\hline MFP & monofluorfosfato de sódio \\
\hline $\mathrm{mL}$ & mililitro \\
\hline $\mathrm{mM}$ & milimolar \\
\hline $\mathrm{mm}$ & milímetro \\
\hline $\mathrm{mm}^{2}$ & milímetro quadrado \\
\hline
\end{tabular}




$\begin{array}{ll}\mathrm{mmol} / \mathrm{L} & \text { milimol por litro } \\ \mathrm{NaF} & \text { fluoreto de sódio } \\ \mathrm{Na}_{2} \mathrm{SiF}_{6} & \text { hexafluoreto de silício dissódico } \\ \mu \mathrm{g} & \text { micrograma } \\ \mu \mathrm{L} & \text { microlitro } \\ \mathrm{mg} & \text { miligrama } \\ \mathrm{mL} & \text { mililitro } \\ \mathrm{mV} & \text { milivoltagem } \\ n & \text { tamanho da amostra } \\ \mathrm{NaOH} & \text { hidróxido de sódio } \\ \mathrm{NaF} & \text { fluoreto de sódio } \\ \mathrm{NaH}{ }_{2} \mathrm{PO}_{4} .2 \mathrm{H}_{2} \mathrm{O} & \text { fosfato de sódio di-hidratado } \\ \mathrm{r} & \text { coeficiente de correlação } \\ \mathrm{p} & \text { nível de significância } \\ \mathrm{pH} & \text { potencial hidrogênico } \\ \mathrm{ppm} & \text { partes por milhão } \\ \mathrm{SiF}{ }_{6}^{2-} & \text { íon hexafluorsilício } \\ \mathrm{TISAB} & \text { total ionic strength adjustment buffer } \\ { }^{\circ} \mathrm{C} & \text { (tampão de ajuste da força iônica total) } \\ \sim & \text { graus Celsius } \\ & \text { marca registrada } \\ & \end{array}$


Resumo 


\section{Resumo}

Este estudo in situ investigou o efeito de um bochecho com lactato de cálcio aplicado previamente ao dentifrício fluoretado na desmineralização do esmalte hígido e na remineralização do esmalte com lesão de cárie artificial, bem como na composição da placa bacteriana. Durante 4 fases de 14 dias cada, 10 voluntários utilizaram dispositivos palatinos contendo 4 blocos de esmalte bovino (4X4X2.5mm): dois hígidos que foram submetidos a um baixo desafio cariogênico $(H)$ e dois com lesão de cárie artificial $(L)$ formada in vitro, usandose uma solução tampão de acetato $\left(16 \mathrm{~h}, 37^{\circ} \mathrm{C}\right)$. Três vezes ao dia, logo após as refeições, a solução de sacarose a $20 \%$ era gotejada em uma fileira de blocos ( $\mathrm{H}, 3$ gotas/bloco), enquanto na outra fileira $(\mathrm{L})$ nada foi realizado. Após 5 minutos de espera, o aparelho retornou a boca e o voluntário bochechou, durante $1 \mathrm{~min}, 10 \mathrm{~mL}$ de solução de lactato de cálcio $150 \mathrm{mM}$ ou água deionizada (placebo). Em seguida, o voluntário removeu o aparelho e gotejou uma solução de dentifrício (1:3) com ou sem flúor (placebo) nos quatro blocos (3 gotas/bloco). Durante 1 minuto, o voluntário escovou seus dentes com o mesmo dentifrício aplicado nos blocos. Ao finalizar o tempo, o aparelho retornou a boca e por fim, enxaguou-se a boca com $10 \mathrm{~mL}$ de água da torneira $(0,7 \mathrm{ppm} F)$. As alterações do esmalte foram avaliadas pela porcentagem de alteração da dureza (\%SMHC), perda mineral $(\Delta \mathrm{Z})$ e biópsia básica para remoção de flúor fracamente ligado, solúvel em álcali. A placa bacteriana foi coletada para posterior análise de $\mathrm{F}$ e $\mathrm{Ca}$. Os dados foram analisados por ANOVA. O uso do bochecho de Ca previamente ao dentifrício fluoretado, produziu um aumento significativo nas concentrações de $F$ na placa e nos blocos com lesão de cárie artificial, em comparação ao uso apenas do dentifrício fluoretado. Entretanto, o bochecho prévio com $\mathrm{Ca}$, não reduziu a desmineralização.

Palavras-chave: cárie dentária; biofilme dentário; desmineralização; cálcio, dentifrício fluoretado. 


\section{Introdução}



2 Introdução 


\section{Introdução}

A cárie dentária é uma doença de etiologia multifatorial. Entre os fatores relacionados ao seu desenvolvimento, tem-se dado destaque ao consumo de açúcares, principalmente a sacarose. Uma vez formada a placa bacteriana, após o metabolismo de açúcares por parte das bactérias tem-se como produto ácidos, que podem levar a uma perda de minerais do esmalte, processo chamado desmineralização (THYLSTRUP; FEJERSKOV, 1994) ${ }^{100}$. O papel da sacarose na etiologia da cárie dentária não se resume à facilitação da formação de placa bacteriana e produção de ácidos. CURY et al. ${ }^{28}$ (1997) analisaram in situ o papel da sacarose na composição da placa dentária. Os autores mostraram que uma exposição freqüente de sacarose (8 vezes ao dia) reduziu significativamente as concentrações de cálcio, flúor e fósforo na placa dentária e aumentou a concentração de polissacarídeos álcali-solúveis, sugerindo que a cariogenicidade não seria atribuída ao aumento da porosidade, mas à baixa concentração desses íons.

Em um outro estudo in situ realizado por CURY et al. ${ }^{26}$ (2000) foi relatado que a placa dentária formada na presença da sacarose é mais cariogênica do que na presença da glicose mais frutose, encontrando também uma baixa concentração de cálcio $(\mathrm{Ca})$, fósforo $(\mathrm{P})$ e flúor $(\mathrm{F})$ na mesma.

Desde a década de 40, o flúor revelou-se um grande aliado à prevenção de cárie dentária. Estudos mostraram que a exposição dos dentes ao $\mathrm{F}$ pela ingestão de água fluoretada, reduz a prevalência de cárie entre 25\% a 80\%, com uma média de redução aproximada de $50 \%$. Já os dentifrícios fluoretados levam a uma redução um pouco menor, da ordem de $15 \%$ a $30 \%$, com uma média de 25\% (ARNOLD et al. ${ }^{10}$ 1962; AST; FITZGERALD ${ }^{11}$, 1962; BLAYNEY; HILL $^{15}$, 1967; MELBERG ${ }^{59}$, 1990; O'MULLANE ${ }^{66}, 1990$ ).

Hoje sabemos dos benefícios do F aplicado sobre a superfície dental, o quão ele é responsável pela diminuição da solubilidade do esmalte em meio ácido, inibindo a desmineralização e acelerando a remineralização, além de possuir efeitos bactericidas e bacteriostáticos, dependendo de sua concentração (HAMILTON ${ }^{39}$, 1990; KOULOURIDES ${ }^{46}$, 1990; TEN CATE; ARENDS $^{95}, 1977$; TEN CATE; DUIJSTERS $\left.{ }^{96,97}, 1983\right)$. 
Não está claro o motivo pelo qual dentifrícios fluoretados, cuja concentração de flúor geralmente varia de 900 a 1500 ppm, não têm mostrado ser mais eficientes que a água fluoretada, contendo em média de 0,6 a 0,8 ppm $\mathrm{F}$, na prevenção de cáries. Considerando a dose de $\mathrm{F}$, seria esperado que o uso regular de dentifrícios produzisse uma concentração de $\mathrm{F}$ na placa bem maior, a qual, teoricamente, teria um melhor efeito cariostático. Sabe-se que a concentração de F na placa e na saliva aumenta bastante durante o uso do dentifrício fluoretado, mas, devido ao enxágüe da boca e à produção de nova quantidade de saliva, a qual tem menos $F$, tal concentração cai rapidamente até se aproximar ou mesmo atingir um nível basal dentro de 2 ou 3 horas (BRUUN; GIVSKOV; THYLSTRUP ${ }^{19}$, 1984; SIDI ${ }^{89}$, 1989; FUKUSHIMA et al. ${ }^{37}$, 2000). Assim, pode ser que apesar de uma ou duas elevações transitórias por dia, de acordo com a freqüência de escovação, as concentrações de $F$ na placa e na saliva durante a maior parte do dia são similares.

Deste modo, um grande desafio é manter os níveis de flúor na saliva e na placa elevados por mais tempo. Neste aspecto há que se considerar o papel do fluoreto cálcio $\left(\mathrm{CaF}_{2}\right)$ ou material " $\mathrm{CaF}_{2}$-like" contaminado com fosfato, que é o maior produto de reação durante o tratamento tópico com $\mathrm{F}$ dos tecidos dentais mineralizados. Evidências recentes têm mostrado que o $\mathrm{CaF}_{2}$ é formado não só na superfície, mas também no interior do esmalte. A concentração mínima de $F$ requerida para a formação do $\mathrm{CaF}_{2}$ não é bem conhecida e pode depender da disponibilidade de $\mathrm{Ca}$ a partir do fluido da placa ou mesmo da dissolução dos tecidos dentais mineralizados. Além disto, a adsorção superficial de $\mathrm{F}$ aos cristais pode elevar as concentrações locais, atingindo-se níveis necessários para a formação de $\mathrm{CaF}_{2}$. Tem-se sugerido que o $\mathrm{CaF}_{2}$ atue como um reservatório de $\mathrm{F}$ controlado pelo $\mathrm{pH}$. Os responsáveis por este controle são fosfato e proteínas, que estabilizariam o $\mathrm{CaF}_{2} \mathrm{em} \mathrm{pH}$ neutro. Em pHs mais baixos, os grupamentos fosfato se ligam a prótons, o que provoca dissolução do $\mathrm{CaF}_{2}$, levando a uma liberação de íons Ca e F, que irão inibir a desmineralização e acelerar a remineralização. Os fatores que aumentam a formação de $\mathrm{CaF}_{2}$ são o aumento da concentração de $\mathrm{F}$ do agente e do tempo de exposição a ele, ou o uso de um agente com baixo $\mathrm{pH}$, uma vez que o $\mathrm{CaF}_{2}$ formado em $\mathrm{pH}$ mais baixo contém menos fosfato interno e é menos solúvel (RÖLA $^{77}$, 1988; TEN CATE ${ }^{94}, 1997$; OGAARD ${ }^{64}, 2001$ ). 
WHITFORD et al. ${ }^{119}$ (2001) avaliaram as concentrações de F na saliva e placa total após o uso por 7 dias de dentifrício fluoretado (1000 ppm F, NaF) ou placebo, em uma comunidade abastecida com água fluoretada. Os autores verificaram que o uso do dentifrício fluoretado promoveu aumentos significativos nas concentrações de F na saliva após 1 e 12 h da escovação, quando comparados ao uso do dentifrício placebo. Entretanto, a concentração de $\mathrm{F}$ na placa $12 \mathrm{~h}$ após o uso de dentifrício fluoretado não foi diferente do placebo. Estes dados suportam a hipótese de que a concentração de $F$ na placa ao longo do dia é depende mais da concentração de Ca na placa, que se ligaria ao $F$, que da concentração de F no veículo. Seguindo este raciocínio, a realização de um bochecho com $\mathrm{Ca}$, previamente à escovação com dentifrício fluoretado, poderia servir como um mecanismo auxiliar para se aumentar à retenção do F no esmalte dentário. Num experimento subseqüente, o mesmo grupo de autores (WHITFORD et al. ${ }^{117}$, 2005) observou que numa comunidade não fluoretada, diferentemente do observado para a comunidade fluoretada, todos os níveis de $\mathrm{F}$ encontrados na placa e na saliva associadas com o uso de dentifrício fluoretado foram significantemente mais altos que os níveis associados com o dentifrício placebo. Estes resultados sugerem que a eficácia cariostática de um dentifrício fluoretado deve ser maior em áreas sem fluoretação das águas. Também foi encontrada uma forte correlação positiva entre a concentração de cálcio e de flúor presente na placa, à semelhança dos resultados encontrados previamente na comunidade fluoretada, sugerindo um importante papel do cálcio da retenção do flúor na placa bacteriana.

Ainda neste sentido, VOGEL et al. ${ }^{107}$ (2004) observou que um prébochecho com uma solução de cálcio concentrada, que deveria formar um reservatório tissular de cálcio, aumentou a concentração de $\mathrm{F}$ presente na saliva após o uso de um enxaguatório fluoretado (225 ppm F). Os autores testaram as concentrações de lactato de cálcio a 30, 150 e 300 mM, e observaram um melhor resultado com a concentração de 150 mM em relação à concentração de flúor presente na saliva. Os autores concluíram que um aumento no cálcio lábil através do uso de um bochecho de cálcio antes da aplicação de um bochecho ou dentifrício fluoretado pode aumentar bastante a retenção oral de $\mathrm{F}$, e conseqüentemente a concentração salivar de $\mathrm{F}$. 
Desta forma, é interessante avaliar o efeito do uso de um bochecho de Ca, previamente à escovação com dentifrício fluoretado, na redução da desmineralização e no aumento da remineralização do esmalte dental bovino e na composição da placa bacteriana formada. 


\section{Revisão da Literatura}


8 Revisão da Literatura 


\section{Revisão da Literatura}

Esta revisão da literatura irá abordar os seguintes itens:

2.1 Estudos in situ

2.2 Avaliação da perda mineral do esmalte

2.3 Concentração de íons na placa bacteriana

2.4 Efeito da sacarose sobre a placa bacteriana

2.5 Efeito do bochecho de Ca no esmalte e na placa bacteriana

2.6 Determinação de $\mathrm{F}$ no esmalte

\subsection{Estudos in situ}

Em 1974, KOULOURIDES et al. ${ }^{48}$, realizaram um estudo in situ para investigar o efeito do F sobre o esmalte bovino hígido ou desmineralizado, sob condição cariogênica ou não cariogênica. Os blocos foram fixados bilateralmente em próteses inferiores, sendo um hígido e um desmineralizado de cada lado. Em apenas um dos lados foi fixada uma gase para servir de proteção para colonização bacteriana e provocar um desafio cariogênico. Para isso, este mesmo lado era imerso em solução de sacarose a $3 \%$ contendo 1 ppm de $\mathrm{F}$, enquanto o outro lado era imerso em água contendo $1 \mathrm{ppm}$ de $\mathrm{F}$. Participaram deste estudo três voluntários, que utilizaram as próteses continuamente por uma semana, exceto durante as quatro imersões diárias de 10 minutos cada. Os blocos foram avaliados quanto à alteração na dureza e incorporação de F. Em condições não cariogênicas, foi encontrada uma remineralização parcial e uma alta incorporação de $F$ no esmalte desmineralizado. Já no esmalte hígido houve pequena perda de dureza e menor incorporação de F. O desafio cariogênico provocou perda de dureza e alta incorporação de $\mathrm{F}$ ao esmalte, tanto hígido quanto desmineralizado, porém o esmalte hígido apresentou maior perda de dureza e menor incorporação de $\mathrm{F}$ que o esmalte desmineralizado.

ØGAARD et al. ${ }^{65}$, em 1990, investigaram, in situ, o efeito cariostático do F sobre o esmalte (flúor solúvel em $\mathrm{KOH}$, flúor fracamente unido ou fluoreto de cálcio) e do $\mathrm{F}$ dentro do esmalte (flúor insolúvel em $\mathrm{KOH}$ ou flúor firmemente 
unido). Foram utilizados pares homólogos de pré-molares extraídos, sendo um deles usado como controle (sem tratamento), enquanto do outro foram obtidos dois blocos, os quais foram submetidos a um tratamento com NaF a $2 \%$ por 24 horas. Posteriormente, um dos blocos foi tratado com $\mathrm{KOH} 1 \mathrm{~mol} / \mathrm{L}$ duas vezes, por 24 horas, para a remoção do $\mathrm{F}$ solúvel, permanecendo apenas o $\mathrm{F}$ insolúvel em $\mathrm{KOH}$. O outro bloco não foi tratado com $\mathrm{KOH}$, permanecendo então o $\mathrm{F}$ total, ou seja, tanto o $\mathrm{F}$ solúvel como o insolúvel em $\mathrm{KOH}$. Cinco voluntários participaram deste estudo, em três fases de quatro semanas cada, período durante o qual utilizaram dentifrício fluoretado. Em cada fase, o voluntário usou um dispositivo acrílico palatino removível contendo três blocos de um mesmo grupo, cobertos com bandas ortodônticas para acúmulo de placa bacteriana. Os blocos foram seccionados e avaliados por microrradiografia em relação à profundidade da lesão e perda mineral. Os resultados indicam que o F solúvel em $\mathrm{KOH}$ reduziu a perda mineral em $68 \%$ e a profundidade da lesão em $63 \%$, quando comparado ao grupo controle. Não foi observada diferença estatisticamente significante entre o grupo controle e o grupo com $\mathrm{F}$ insolúvel em $\mathrm{KOH}$.

A influência dos métodos de esterilização dos blocos a serem utilizados nos testes de cariogenicidade in situ na sua microdureza superficial foi testada por CHANDLER ${ }^{23}$, em 1990. O autor preparou os blocos de esmalte bovino para a realização dos testes de microdureza e submeteu-os a 3 métodos de esterilização: autoclave, radiação gama e óxido de etileno. Posteriormente, avaliou a alteração na microdureza e a morfologia superficial dos blocos, através de microscopia eletrônica de varredura. Nenhum dos 3 métodos altrou a morfologia superficial dos blocos; entretanto, a autoclave causou um amolecimento significante do esmalte. Segundo a literatura, a radiação gama pode alterar a resposta do esmalte em testes de cariogenicidade, tornando-o mais resistente. $\mathrm{O}$ óxido de etileno não alterou a microdureza do esmalte, mas este método de esterilização tende a desaparecer, à custa da toxicidade do gás, sua alta capacidade explosiva e à complexidade de seu uso. Devido à ausência de outros métodos, para o autor a radiação gama parece ser 0 método mais adequado para a substituição do óxido de etileno, na esterilização de blocos de esmalte. 
SCHÄFER; RAVEN; PARR ${ }^{85}$, em 1992, afirmaram que o maior critério para avaliar o valor de um modelo experimental é o grau de correspondência entre seus resultados e aqueles obtidos do processo real. Para isso, é necessário que um modelo com alta sensibilidade seja utilizado. Os autores avaliaram a influência de dois fatores específicos (severidade da lesão inicial e local de avaliação no esmalte) na performance da remineralização do esmalte humano. Para avaliar a influência da severidade da lesão, foi realizado um estudo in situ, com blocos de esmalte de pré-molares, os quais foram desmineralizados em gel acidulado, $\mathrm{pH} 4,5$, durante 2 a 3 semanas, originando lesões subsuperficiais com uma variação do $\Delta Z$ (\%vol mineral $x \mu m)$ de 800 a 6000. Estes espécimes foram fixados em próteses parciais removíveis de adultos voluntários, que usaram dentifrício fluoretado por 6 semanas. Após este período, os espécimes foram seccionados e analisados em microrradiografia quanto ao tamanho das lesões. Para avaliar o efeito do local de avaliação no esmalte (terços cervical, médio e oclusal) na desmineralização, foi realizado um estudo in vitro. Neste estudo, 28 secções longitudinais de esmalte desmineralizado em gel acidulado foram analisadas por meio de microscopia de luz polarizada. Os resultados do $1^{\circ}$ estudo indicaram que ocorreu variação no tamanho da lesão inicial quando houve desmineralização ou remineralização durante o tratamento in situ. As amostras com $\Delta Z$ maior que 3500. Isto significa que a distribuição dos espécimes no grupo de estudo deve ser bem balanceada quanto ao tamanho da lesão inicial, pois espécimes com lesões maiores parecem ser mais susceptíveis à remineralização, enquanto aqueles com lesões menores podem ser mais indicados para estudos de desmineralização. Quanto ao local de avaliação no esmalte, os resultados mostraram que a profundidade da lesão aumenta do terço coronário para a cervical.

Em 1991, MACPHERSON et al. ${ }^{54}$ avaliaram se a placa bacteriana in situ sobre os blocos e fatias de esmalte e aquela formada sobre uma base de acrílico são semelhantes à placa formada naturalmente sobre as superfícies lisas dos dentes. Cinco voluntários utilizaram, durante uma semana, um dispositivo contendo 4 blocos e uma fatia de esmalte, que era removido apenas 2 vezes ao dia para higienização dos dentes naturais (MACPHERSON; 
MACFARLANE; STEPHEN ${ }^{56}$, 1990; MACPHERSON et al. ${ }^{55}$, 1990). A placa bacteriana foi coletada das fatias e blocos de esmalte, da área do acrílico junto aos blocos e dos primeiros molares permanentes inferiores dos voluntários, que estavam em contato com o acrílico do dispositivo. Posteriormente, foi coletada a placa formada por uma semana, sem o uso do dispositivo, sobre a mesma superfície dos molares permanentes. Além disso foram avaliados o $\mathrm{pH}$ e a quantidade de lactato/acetato da placa presente sobre os blocos de esmalte e sobre os primeiros molares dos voluntários, antes e após um bochecho com sacarose a 10\%. Apesar de algumas diferenças quantitativas terem sido observadas entre as proporções de bactérias isoladas das diferentes superfícies, qualitativamente a microbiota foi muito similar, não sendo encontrada também diferença entre o $\mathrm{pH}$ e as proporções de lactato/acetato, nas diferentes placas, após o bochecho com sacarose. Houve uma variação significante entre os voluntários na composição da placa em diferentes superfícies. A microbiota predominante na placa bacteriana sobre os blocos de esmalte foi mais próxima daquela formada sobre dentes naturais do que a formada sobre fatias de esmalte. Os autores concluíram que a plca formada in situ é similar àquela formada sobre a dentição natural, mas esta semelhança pode ser diminuída pela utilização de uma tela sobre os blocos, para promover o acúmulo de placa.

FEATHERSTONE; ZERO ${ }^{36}, 1992$ relataram suas experiências com o uso de testes in situ. Segundo eles, apesar desses testes simularem como nenhum laboratório as condições da cavidade bucal, estão sujeitos a diversas variáveis que devem ser ao máximo controladas como, por exemplo, pela realização de estudos cruzados. À medida que relatam suas experiências com alguns tipos de metodologias in situ, os autores colocam os critérios necessários à execução adequada desses testes, entre eles a seleção e o seguimento dos voluntários, o preparo do dispositivo intrabucal e o método de avaliação da des ou remineralização.

VERNON et al. ${ }^{102}$, em 1992, escreveram a respeito da influência de certos fatores nos estudos in situ, com base em um trabalho de remineralização de lesões de cárie artificial através de dentifrícios fluoretados. Dentre as sugestões dos autores, está a avaliação da cooperação do voluntário Tatiana de Almeida Furlani 
através de diários indicando a freqüência do uso do tratamento; no experimento por eles relatado, houve diferença, porém não estatisticamente significante, quando dados de todos os voluntários foram comparados com os dados daqueles que relataram cooperação, o que sugere que este tipo de avaliação da colaboração é importante.

Um estudo in situ realizado por KOULOURIDES; CHIEN ${ }^{47}$, em 1992, comparou a cariogenicidade de soluções de sacarose a 10\% contendo 1, 3, 10 e 30 ppm de F com uma solução controle contendo sacarose a $10 \%$ sem F. Os blocos foram submetidos à microdureza superficial inicial, metade da sua superfície foi desmineralizada in vitro, permanecendo metade da superfície íntegra. Outros blocos de esmalte foram submetidos à desmineralização em toda a superfície. Os voluntários foram instruídos para imergir um dos lados da prótese na solução de sacarose a $10 \%$, durante 10 minutos, em seguida o outro lado foi imerso na solução de sacarose a $10 \%$ contendo as concentrações de $\mathrm{F}$ acima descritas. Os procedimentos foram realizados 4 vezes ao dia, durante 7 dias para cada etapa e a posição dos blocos na prótese foi invertida em todas as fases do experimento. Todos os blocos foram ainda submetidos ao teste de resistência ácida, a mesma solução desmineralizante utilizada anteriormente, juntamente com 0 teste de microdureza, nos intervalos de 1, 3 e 5 dias. Foi ainda realizada a análise da concentração de $F$ na superfície dos blocos. A presença de $F$ nas soluções fez com que diminuísse a desmineralização dos blocos íntegros e para os blocos que sofreram desmineralização prévia houve o aumento da remineralização. $\mathrm{Na}$ maioria dos casos, os blocos submetidos à solução de sacarose com $\mathrm{F}$ foram significantemente mais ácido-resistentes do que os blocos submetidos à solução de sacarose, quando da análise da microdureza. A comparação entre todas as concentrações de $\mathrm{F}$ utilizadas demonstrou diferença significativa somente nas 3 primeiras camadas removidas.

TEN CATE; VAN DE PLASSCHE-SIMONS; VAN STRIJP ${ }^{98}$, em 1992, colocaram em artigo a importância do controle das diversas variáveis presentes nos testes in situ. Com relação à seleção dos voluntários, o ideal é trabalhar com indivíduos jovens, nos quais a cárie é mais pronunciada. A respeito do substrato, o esmalte bovino é mais poroso que o humano, podendo levar a 
diferenças nas taxas de des ou remineralização. A utilização de tela para promover o acúmulo de placa bacteriana pode levar à formação de uma microbiota de composição diferente daquela formada sobre superfícies livres; por outro lado, a colocação dos espécimes em um sítio com recessão leva a diferentes padrões de desmineralização e remineralização na porção central periférica do espécime. Com relação ao método de avaliação da perda/ganho de mineral, a microdureza superficial parece representar bem as alterações ocorridas na camada mais superficial da lesão, sendo um método mais sensível que a microrradiografia nessa região.

Foi realizada uma revisão a respeito da metodologia envolvida nos estudos in situ por MANNING; EDGAR ${ }^{57}$, em 1992. Com relação ao substrato, o esmalte bovino apresenta pouca variabilidade, principalmente após a remoção de 100 a $200 \mu \mathrm{m}$ de sua superfície externa. Dentre os métodos de avaliação da perda ou ganho de mineral estão a microdureza, a microrradiografia e a microscopia de luz polarizada. O primeiro é um teste sensível, que pode ser utilizado no mesmo espécime antes e após os tratamentos, mas que não fornece medidas diretas do conteúdo mineral e requer uma superfície polida. Já a microrradiografia e a microscopia de luz polarizada necessitam que o dente seja seccionado.

MELLBERG ${ }^{60}$, em 1992, fez uma revisão sobre os substratos nos estudos in situ. O esmalte humano é considerado o substrato de escolha, mas uma de suas desvantagens é a sua pouca disponibilidade em quantidade e qualidade, ele normalmente não tem uma superfície plana ampla e sua composição e resposta ao teste variam de acordo com a idade. O esmalte de incisivos bovinos é facilmente obtido em grande quantidade e boas condições, apresenta superfícies planas amplas e possui uma composição menos variável que o esmalte humano, devido à menor concentração de $\mathrm{F}$ e por não passar por desafios cariogênicos, resultando em uma resposta experimental mais padronizada. Ele também é mais poroso que o esmalte humano, apresentando uma taxa de difusão e formação da lesão mais rápida. O acúmulo de placa bacteriana sobre os blocos de esmalte pode ser promovido pela colocação de uma cobertura sobre os espécimes, para aumentar a taxa de formação da lesão e padronizar o desafio cariogênico, os espécimes cobertos podem ser Tatiana de Almeida Furlani 
expostos extrabucalmente a uma solução cariogênica. Entretanto, o desenvolvimento de cárie em espécimes tratados com sacarose várias vezes ao dia é severo e não necessariamente natural. Com relação à difusão de íons, os espécimes cobertos por tela são mais representativos de áreas interproximais, aqueles colocados abaixo do nível do aparelho são mais representativos de superfícies lisas.

Em 1994, LINGSTRÖM et al. ${ }^{51}$ avaliaram a desmineralização do esmalte in situ e a alteração no $\mathrm{pH}$ da placa em relação ao consumo de alimentos à base de amido e de sacarose. Oito voluntários utilizaram uma prótese total inferior contendo blocos de esmalte e dentina, montados $1 \mathrm{~mm}$ abaixo do acrílico, durante 3 períodos cruzados de 21 dias: (a) consumo de 12 a 15 vezes ao dia de alimentos contendo amido; (b) consumo de 12 a 15 vezes ao dia de alimentos contendo sacarose; (c) período controle. A desmineralização dos blocos foi avaliada através da microdureza superficial e microrradiografia. Não houve diferença estatisticamente significante entre a microdureza dos blocos de esmalte nos 3 períodos, mas, numericamente, o aumento no comprimento de indentação foi maior após o consumo de sacarose e amido. No início e final de cada período experimental, a saliva estimulada dos voluntários foi coletada para avaliação do número de estreptococos mutans e lactobacilos. Houve aumento na contagem dessas bactérias nos 3 períodos, sem diferença estatisticamente significante entre eles. A queda no $\mathrm{pH}$ após um bochecho de 1 min com sacarose a $10 \%$ foi maior na placa formada sobre os blocos nos períodos de consumo de amido e sacarose.

Segundo ZERO ${ }^{122}$, em 1995, estudos de cárie in situ envolvem o uso de dispositivos que criam condições definidas na boca de humanos que simulam o processo de cárie dentária, servindo como ponte entre uma situação clínica natural não controlada e uma situação laboratorial altamente controlada. Esses modelos reproduzem e exibem a natureza multifatorial da cárie dentária que inclui: um substrato dentário, o esmalte ou dentina, a formação ou presença de placa bacteriana com potencial cariogênico, o desafio cariogênico promovido pela dieta ou controlado experimentalmente, e o tempo que é determinado pelo cumprimento do período experimental. Portanto, a intenção desses sistemas de modelos in situ é imitar o que ocorre no processo natural da cárie, fornecer 
informações clinicamente relevantes em um curto período de tempo sem causar danos irreversíveis na dentição natural. O autor ainda descreve que os blocos de esmalte bovino são menos variáveis, mais porosos, por isso desmineralizam mais rápido e são considerados uma alternativa aceitável ao esmalte humano, diminuindo o tempo do teste e a variabilidade da resposta do substrato no modelo experimental. ZERO defende ainda o uso da microdureza superficial como método de análise mineral, por ser altamente sensível e reprodutível, podendo ser utilizado para estudos iniciais de desmineralização e remineralização do esmalte.

Preocupados com a infecção cruzada que os estudos in situ utilizando substrato humano ou bovino podem promover AMAECHI; HIGHAM; EDGAR ${ }^{3}$, em 1998, publicaram um artigo avaliando 4 métodos de esterilização (autoclave, radiação gama, hipoclorito de sódio e povidine-iodine) de blocos de incisivos bovinos. Após a extração, os dentes foram armazenados em solução de timol a 0,1\%. A contagem de microorganismos remanescentes após a esterilização indicou crescimento, apenas no grupo controle, de S. áureos e bacilos. Após a esterilização, os blocos foram desmineralizados in vitro e a perda mineral e a profundidade da lesão foram avaliadas através de microrradiografia. Houve diferença numérica entre a lesão de cárie artificial criada nos dentes esterilizados por diferentes métodos, que não foi estatisticamente significante quando comparada ao grupo controle. Entre os germes presentes nos blocos controle estavam microorganismos comensais da mão e pele, ao contrário de S. mutans, S. sanguis e outros que são cultivados de dentes imediatamente após a extração. Isto sugere que a imersão em solução de timol a $0,1 \%$ foi suficiente para evitar a infecção cruzada, não sendo necessário nenhum outro método de esterilização, desde que os blocos de esmalte sejam manipulados assepticamente.

Em 2001, SHORE et al. ${ }^{88}$ avaliaram o dispositivo de Leeds, utilizado em estudos in situ, que possibilita a recuperação da placa bacteriana acumulada sobre o substrato dentário de maneira intacta. Foram utilizadas fatias de esmalte obtidas de dentes humanos, as quais foram planificadas e desmineralizadas em gel acidificado por 3 semanas. A microdureza Vickers inicial foi determinada e um anel de nylon foi colocado sobre o esmalte Tatiana de Almeida Furlani 
desmineralizado, formando um dispositivo de Leeds. Participaram deste estudo cruzado e duplo-cego 22 voluntários, o qual foi realizado em 2 fases de 28 dias cada, de acordo com o dentifrício usado: fluoretado (1500 ppm, NaF) ou placebo. Dois dispositivos foram fixados nos molares superiores de cada voluntário sendo um do lado direito e outro do lado esquerdo, e a higiene bucal foi realizada como de costume com um dos dentifrícios. Após 28 dias, os dispositivos foram removidos para análise microbiológica da placa bacteriana e da microdureza do esmalte. Após 2 semanas de "wash-out", dois novos dispositivos foram fixados e outro dentifrício foi utilizado. Não houve diferença estatisticamente significativa na contagem total de bactérias anaeróbicas, estreptococos mutans ou lactobacilos, em função do dentifrício usado. Porém, houve maior ganho de microdureza com o uso de dentifrício fluoretado. Os autores concluíram que o dispositivo foi capaz de medir o efeito do dentifrício fluoretado na desmineralização do esmalte e na microbiologia da placa.

Em 2002, LAGERWEIJ; TEN CATE ${ }^{49}$ realizaram um estudo in situ para determinar o máximo de remineralização que poderia ser alcançado com aplicações diárias de flúor em alta concentração. Para isso, compararam a eficácia da aplicação diária de um gel fluoretado (NaF, 1250 ppm F, pH 4,5) em combinação com dentifrício fluoretado ( $\mathrm{NaF} 1450$ ppm F), com o dentifrício fluoretado somente. Participaram do estudo 26 voluntários que utilizaram uma prótese parcial removível inferior, sendo que 14 usaram apenas o dentifrício fluoretado, enquanto 12 usaram o dentifrício e o gel. Foram preparados espécimes de esmalte bovino, que foram desmineralizados em gel (8\% metilcelulose, 0,1 M de ácido lático, $\mathrm{pH} 4,6)$ por 1 semana. Os voluntários utilizaram as próteses com os blocos por 4 semanas, escovando os dentes 2 vezes por dia por 2 minutos e, no outro grupo, além da escovação, foram instruídos a aplicar o gel sobre os espécimes fora da boca. Após 4 minutos, o gel foi lavado em água de torneira. Os voluntários foram instruídos a não escovar os espécimes. Após o período experimental, os espécimes foram seccionados e analisados em relação à concentração de $F$ fracamente ligado ao esmalte e em relação à perda mineral, pela técnica de microrradiografia. A associação do gel com o dentifrício diminuiu a lesão em $54 \%$, enquanto o uso isolado de dentifrício reduziu em 44\%, mas esta diferença não foi 
estatisticamente significativa. Ambos os tratamentos foram capazes de remineralizar a lesão nas camadas mais profundas do esmalte. No entanto, observou-se que a camada superficial foi mais remineralizada com a associação entre gel e dentifrício. Esta associação também proporcionou maiores concentrações de $F$ fracamente ligado ao esmalte. Portanto, a presença de alta concentração de flúor sobre o esmalte proporciona uma remineralização mais superficial do esmalte.

Em 2003, TENUTA et al. ${ }^{99}$ avaliaram o efeito de alguns fatores e da composição da placa bacteriana na progressão da cárie in situ. Para a seleção dos voluntários foram avaliados alguns fatores salivares (fluxo, a capacidade tampão e os níveis de estreptococos mutans). Durante 3 períodos distintos de 4,7 e 10 dias, 13 voluntários utilizaram um dispositivo palatino contendo 4 blocos de esmalte bovino, protegidos de distúrbios mecânicos por uma tela plástica, nos quais eles gotejaram uma solução de sacarose a 20\%, 10 vezes por dia. A higiene bucal foi realizada utilizando dentifrício não fluoretado. Os estreptococos mutans, Ca e polissacarídeos insolúveis $(\mathrm{PI})$ foram quantificados na placa formada sobre os blocos após cada período. A desmineralização do esmalte foi avaliada pela porcentagem de perda da microdureza superficial (\% PDS). Houve desmineralização do esmalte em todos os períodos avaliados $(p<0,05)$, sendo que a \%PDS aumentou significativamente com o tempo (de 13,8 para 48,3\%). As concentrações de Ca e PI na placa bacteriana não foram diferentes entre os tempos experimentais, mas houve correlação negativa significativa entre a concentração de $\mathrm{Ca}$ e \%PDS e correlação positiva significativa entre a concentração de PI e \%PDS. Os fatores salivares avaliados inicialmente e os níveis de estreptococos mutans na placa não apresentaram correlação estatisticamente significativa com a \%PDS. Os resultados mostraram que a desmineralização do esmalte depende do tempo e está mais relacionada com a composição da placa bacteriana formada do que com os fatores salivares inicialmente avaliados.

Em 2004, PAES LEME et al. ${ }^{68}$ avaliaram o efeito da combinação entre flúor fosfato acidulado (FFA) e dentifrício fluoretado, bem como o efeito da freqüência do desafio cariogênico, sobre a desmineralização do esmalte e a composição da placa bacteriana. Para tal, foi realizado um estudo in situ Tatiana de Almeida Furlani 
cruzado com 16 voluntários, que utilizaram dispositivos palatinos removíveis com espécimes de esmalte bovino cobertos com tela plástica, em 4 fases distintas de 14 dias cada: dentifrício sem F (DP); dentifrício fluoretado (DF); FFA + DP; FFA + DF. O FFA foi aplicado sobre os espécimes anteriormente a fase in situ. Durante o período experimental, os dentifrícios testados foram aplicados 3 vezes por dia (solução com proporção $1 \mathrm{~g}$ dentifrício: $3 \mathrm{~mL}$ de água deionizada). Para provocar o desafio cariogênico, uma solução de sacarose a $20 \%$ foi aplicada 4 ou 8 vezes por dia. Embora a aplicação de FFA tenha aumentado à concentração de $F$ na placa e reduzido a porcentagem de estreptococos mutans, sua combinação com DF não foi capaz de reduzir a perda mineral ou alterar os níveis de $\mathrm{Ca}$, polissacarídeos insolúveis e fósforo na placa, quando comparado ao DF sozinho. Com o aumento da freqüência de aplicação de sacarose, observou-se que houve menos $\mathrm{F}$ e $\mathrm{Ca}$ e mais polissacarídeos insolúveis na placa, com maior perda de dureza superficial e menor conteúdo mineral. No entanto, a freqüência não alterou a concentração de fósforo e a porcentagem de estreptococos mutans. Conclui-se que a associação de dois veículos fluoretados não aumentou o efeito do $F$ na prevenção da formação da lesão de cárie em esmalte, porém a freqüência de exposição ao açúcar potencializou a alteração do esmalte.

Em 2005, SÄRNER et al. ${ }^{84}$ avaliaram o efeito de dois palitos e dois fios dentais sobre o esmalte e dentina desmineralizados, bem como sobre a composição da placa, em um estudo in situ, simulando os espaços interproximais. Participaram da pesquisa 14 voluntários com prótese total, nas quais foram fixados espécimes de esmalte e dentina previamente desmineralizados. Estes espécimes formavam um $\mathrm{V}$ e foram unidos com resina acrílica, simulando um espaço interproximal. Foram realizados 4 períodos cruzados, nos quais comparou-se o uso de palitos com fluoreto de amina $(A m F)$ e fluoreto de sódio $(\mathrm{NaF})$ e o uso de fio dental com $\mathrm{AmF}+\mathrm{NaF}$ e fio sem F. Entre estes 4 períodos houve um período controle sem limpeza proximal. Os indivíduos utilizaram o fio ou o palito, 3 vezes por dia, durante 4 semanas. Os resultados mostraram que todos os dispositivos inibiram uma desmineralização adicional em comparação ao grupo controle, sendo a diferença estatisticamente significativa. Os fios dentais foram mais efetivos na inibição da 
desmineralização em relação aos palitos, principalmente em dentina. O palito com NaF foi mais efetivo que o com AmF. Já o uso de fio dental com $F$ diminuiu a profundidade da lesão em comparação ao sem F. Todos os dispositivos resultaram em um número significantemente menor de microorganismos em comparação ao controle. Com base nos resultados, conclui-se que o melhor dispositivo para a prevenção da cárie interproximal é o fio com F.

MARTINHON et al. ${ }^{58}$, em 2006, avaliaram in situ, o efeito do ferro na composição do esmalte e na formação da placa bacteriana, sob alto desafio cariogênico. Participaram da pesquisa 12 voluntários, em 2 etapas cruzadas de 14 dias cada. Em cada etapa, os voluntários utilizaram dispositivos palatinos contendo 4 blocos de esmalte bovino e escovaram seus dentes com dentifrício não fluoretado. Oito vezes ao dia, os voluntários gotejaram uma solução de sulfato ferroso $15 \mathrm{mM}$ ou água deionizada sobre os espécimes, dependendo da fase experimental. Após 5 minutos, uma solução de sacarose a $20 \%$ foi aplicada sobre os espécimes. As alterações do esmalte foram quantificadas pela microdureza superficial (\%PDS), longitudinal (\%volume mineral) e pela presença de $\mathrm{Ca}, \mathrm{F}$ e Fe. Já a placa bacteriana coletada foi analisada em relação à presença de $\mathrm{F}, \mathrm{Ca}, \mathrm{P}, \mathrm{Fe}$ e carboidratos álcali-solúveis. Na placa tratada com sulfato ferroso houve aumento significativo apenas das concentrações de $\mathrm{P}$ e Fe. Já para o esmalte, o uso de sulfato ferroso diminuiu a porcentagem de perda de dureza superficial (\%PDS) e perda mineral em comparação ao grupo controle. Quanto à composição do esmalte, não houve diferença entre os grupos. Concluiu-se que o Fe causou um aumento na concentração de $\mathrm{P}$ na placa bacteriana, bem como reduziu a perda mineral, tanto na superfície como internamente no esmalte.

\subsection{Avaliação da perda mineral}

Em 1924, PICKERILL ${ }^{74}$ desenvolveu um esclerômetro para medir a dureza dos dentes. O aparelho consistia de uma ponta de diamante e um peso, que eram aplicados sobre a estrutura dentária com pressão crescente, até que se pudesse observar um risco macroscopicamente, após a aplicação de grafite sobre ele. 
Outros métodos de avaliação da dureza dos dentes foram utilizados por diversos pesquisadores. Em 1933, HODGE; MACKAY40, utilizando o teste de Bierbaum, onde o risco era realizado com um diamante e medido através de um microscópio, determinaram a microdureza do esmalte e dentina em diferentes áreas do dente. A microdureza era calculada através da razão entre a área da impressão e a força aplicada e, segundo os autores, seus valores deveriam ser considerados apenas para efeito de comparação.

Dentre os métodos de avaliação da microdureza através da resistência à penetração existentes até a década de 30, nenhum era adequado para utilização na estrutura dentária. Entretanto, em 1939, KNOOP; PETERS; EMERSON $^{45}$ desenvolveram um penetrador em forma de pirâmide, com carga variando de 1 a $500 \mathrm{~g}$, que poderia ser pressionado contra um material. As indentações criadas pelo penetrador possuíam o formato de um losango, sendo o comprimento da diagonal maior 7 vezes o comprimento da diagonal menor e cerca de 30 vezes a profundidade da impressão. O número da dureza KNOOP (KHN) é expresso em $\mathrm{Kg} / \mathrm{mm}^{2}$. Com a utilização do penetrador tipo Knoop, a maior parte da memória elástica do material avaliado tende a deformar a indentação no sentido transversal e não no seu longo eixo, o que permite a avaliação da microdureza de materiais frágeis, assim como a estrutura dentária. O número de dureza Knoop (KNH) é expresso em $\mathrm{Kg} / \mathrm{mm}^{2}$, como a carga necessária para forçar o penetrador até que uma área de $1 \mathrm{~mm}^{2}$ de superfície seja ocupada.

Em 1943, SOUDER; SCHOONOVER ${ }^{90}$ empregaram a microdureza Knoop para estudar o efeito de dentifrícios e soluções contendo açúcar e ácidos na dissolução da superfície e amolecimento do esmalte e dentina. A associação entre açúcar e bactérias no desenvolvimento de cáries foi demonstrada após imersão de fragmentos dentários numa solução de açúcar e saliva: houve dissolução e amolecimento do esmalte e dentina. Ao medirem lesões de mancha branca, os valores de dureza encontrados foram de 250 $\mathrm{KHN}$, contra $350 \mathrm{KHN}$ no esmalte sadio adjacente. Os autores enfatizaram as vantagens da utilização da microdureza no estudo da cárie em relação aos outros métodos existentes na época, permitindo a detecção de alterações na estrutura dentária de maneira rápida e sensível. 
Em 1958, CALDWELL et al. ${ }^{22}$ utilizaram a microdureza para avaliar a taxa de amolecimento de dentes humanos submetidos a desmineralização in vitro. Dentes intactos e polidos foram cobertos por placa bacteriana, cultivada a partir de saliva em um meio de cultura contendo glicose. Dez indentações com penetrador Knoop foram realizadas inicialmente e após a desmineralização in vitro. A microdureza inicial foi ligeiramente maior nas superfícies intactas (367), do que nas polidas (325). A porcentagem de diminuição de dureza por hora foi de 3,4\% para as superfícies intactas e 4,9\% para as superfícies polidas, em média. Os autores consideraram o método promissor para avaliação da taxa de desenvolvimento de cárie in vitro e para o teste de agentes anticariogênicos.

Em um estudo semelhante NEWBRUN; TIMBERLAKE; PIGMAN ${ }^{63}$, em 1959, avaliaram a taxa de amolecimento do esmalte através da microdureza superficial, após exposição dos dentes a um tampão lactato com pH 5,0. Neste experimento foram utilizados dentes humanos, intactos e polidos, e dentes bovinos intactos. A microdureza inicial e após a imersão no tampão por até 10 horas foi avaliada através de 10 indentações com penetrador tipo Knoop, com carga de $500 \mathrm{~g}$ por 10 segundos. A microdureza inicial dos dentes humanos e bovinos foi, em média, 367 e 356, respectivamente. Além disso, a taxa de amolecimento foi ligeiramente maior para os dentes bovinos do que para os humanos. Os dentes polidos apresentaram um menor desvio padrão entre as leituras individuais de microdureza, mas a queda na dureza foi mais rápida do que para as superfícies intactas. Os autores também investigaram se a microdureza inicial tinha correlação com a resistência ao amolecimento, o índice de correlação foi praticamente zero e eles concluíram que a taxa de amolecimento era independente da dureza inicial.

Em 1960, NEWBRUN; PIGMAN ${ }^{62}$ fizeram uma revisão dos métodos até então existentes para determinação da dureza do esmalte e dentina. Ressaltando as vantagens do penetrador Knoop, os autores concluíram que a microdureza é um método sensível e adequado para acompanhar a progressão de lesões de cárie produzidas natural ou artificialmente.

FEAGIN; KOULOURIDES; PIGMAN ${ }^{34}$, em 1969, avaliaram a relação entre perda e ganho de dureza do esmalte e desmineralização ou remineralização. Blocos de esmalte humano e bovino foram utilizados. Cinco indentações foram realizadas inicialmente e outras 5 após o amolecimento e/ou 
endurecimento do esmalte, a uma distância de $60 \mu \mathrm{m}$ das primeiras. A desmineralização foi realizada em tampão acetato de potássio com $\mathrm{pH} 5,0$, por 4 ou 5 h, após a qual uma diminuição em 100 a 120 KHN pôde ser observada. A remineralização foi realizada durante 1 a $6 \mathrm{~h}$ em solução remineralizante descrita pelos autores. A concentração de cálcio e fósforo nas soluções des e remineralizante foi determinada. A diminuição e o aumento do KHN apresentaram uma relação linear com a perda ou ganho de cálcio e fosfato pelo esmalte, o que demonstrou que as medidas de dureza podem ser usadas como indicadoras do seu grau de mineralização.

O efeito da remineralização em lesões de cárie in vitro foi avaliado por TEN CATE; ARENDS ${ }^{95}$, em 1977. Os blocos de esmalte bovino foram cortados, polidos e submetidos ao processo de formação de cárie artificial durante 96. Após a formação das lesões de cárie, os blocos de esmalte forma submetidos a um processo de remineralização por um controle contínuo do $\mathrm{pH}$ e da atividade dos íons $\mathrm{F}$ da solução de remineralização (Ca a $2 \mathrm{mM}, \mathrm{PO}_{4}$ a 1,2 $\mathrm{mM}$ e $\mathrm{F}$ de 0 a 1 ppm em $\mathrm{pH}=7,0)$. A proporção de íons depositados foi determinada $\left(\mathrm{Ca} / \mathrm{PO}_{4}, \mathrm{Ca} / \mathrm{F}, \mathrm{Ca} / \mathrm{OH}\right)$ e a análise das lesões após a remineralização foi feita através de microscopia eletrônica de varredura, pela espectroscopia infravermelha, pela difração de RX e pela análise da dureza. Os autores concluíram que o material depositado mais provável seria a apatita fluoratada e quando adicionado $1 \mathrm{ppm}$ de $\mathrm{F}$ na solução de remineralização houve um aumento do índice de remineralização. Na microscopia eletrônica de varredura observou-se um material cristalino depositado durante a remineralização. A análise da dureza indicou que durante o período de remineralização ocorreu um aumento da dureza no corpo da lesão e da superfície do esmalte.

Para investigar a confiabilidade do teste de microdureza superficial na avaliação de lesões da cárie, ARENDS; SCHUTHOF; JONGEBLOED ${ }^{7}$, em 1979, testaram a microdureza Knoop de 60 dentes bovinos e 50 dentes humanos, desgastados e polidos, após a formação de lesões de cárie artificial. Foram utilizadas cargas de 25, 50, 100, 200 e $500 \mathrm{~g}$ por 10 segundos. A dureza Knoop do esmalte humano foi de $317 \pm 30$ e o esmalte bovino se apresentou ligeiramente mais mole. De acordo com este estudo, quando o comprimento da indentação é medido em função da raiz quadrada da carga, encontra-se uma 
relação linear entre o esmalte humano e bovino hígidos, assim como para o esmalte com lesões artificiais de cárie. Além disso, nem a camada superficial da lesão nem o esmalte sadio subjacente influenciam consideravelmente as indentações. Assim, os autores provaram que as medidas das indentações refletem o grau de descalcificação da lesão, apesar da presença da camada superficial.

No ano seguinte, ARENDS; SCHUTHOF; JONGEBLOED 6 avaliaram a relação entre o comprimento da indentação e a profundidade da lesão. Utilizando a mesma metodologia descrita no artigo anterior, os autores concluíram que existe uma relação linear empírica entre profundidade da lesão de cárie artificial e comprimento de indentação para o esmalte humano e bovino e descreveram uma equação para determinar a profundidade da lesão.

Uma comparação direta entre a análise quantitativa, microrradiografia e a microdureza foi avaliada por FEATHERSTONE et al. ${ }^{35}$, em 1983, usando lesões de cárie artificial em dentes humanos. Após a formação da lesão de cárie artificial, os dentes foram cortados verticalmente no centro da lesão, uma metade submetida à análise de microdureza e a outra metade a análise de microrradiografia. Uma relação linear foi encontrada entre a porcentagem de volume mineral determinada pela microrradiografia, numa gama de $40-90 \%$ de volume mineral. Embora haja diferença entre as propriedades de medida física entre a microdureza e a microrradiografia, a microdureza não deve ser usada somente como uma medida comparativa nas mudanças de dureza, mas como uma medida direta das perdas e ganhos como conseqüência de uma desmineralização/remineralização.

Em 1987, WHITE; FEATHERSTONE ${ }^{115}$ determinaram o efeito de dentifrício fluoretado na progressão de lesão in vitro através da análise da microdureza longitudinal. Os dentes humanos foram submetidos a um modelo de ciclagem de $\mathrm{pH}$, onde houve períodos alternados de des-remineralização por um período de 24 horas, os grupos consistism em dentifrício placebo, dentifrício com NaF a 1100 ppm, e controle, nenhum tratamento. Ao final do período de imersão, os dentes foram coratdos verticalmente, inclusos em resina e polidos. As durezas internas das lesões foram feitas em uma linha perpendicular, iniciando com $25 \mu \mathrm{m}$ da superfície externa do esmalte, seguindo até uma profundidade de $300 \mu \mathrm{m}$. O grupo de dentifrício com NaF foi Tatiana de Almeida Furlani 
extremamente efetivo na redução da progressão da lesão em relação ao grupo placebo e controle. $\mathrm{O}$ tratamento com dentifrício $\mathrm{NaF}$ resultou na diminuição da profundidade da lesão e um aumento no conteúdo mineral, e também foi estatisticamente superior aos 2 grupos nas medidas individuais de 50 a $125 \mu \mathrm{m}$ $(p<0,05$ ANOVA). $A$ análise da área de progressão da lesão indicou que o dentifrício com NaF foi efetivo de 73 a $82 \%$ na redução do avanço da lesão.

Ainda no mesmo ano, WHITE ${ }^{116}$, ao avaliar a capacidade de remineralização in vitro de dentifrícios fluoretados sobre o esmalte desmineralizado, fez uma comparação entre a microdureza superficial e a microrradiografia com relação a remineralização do esmalte. Segundo o autor, o conteúdo mineral da superfície e do esmalte tem relação linear com a diagonal da indentação ou a sua penetração. Entretanto essa relação se restringe a lesões de cárie com pequena profundidade (menos de $50 \mu \mathrm{m}$ ); em lesões subsuperficiais profundas, a microdureza superficial deve ser substituída pela microrradiografia ou pela microdureza longitudinal.

REINTSEMA; ARENDS ${ }^{76}$, em 1988, avaliaram as mudanças na microdureza em esmalte humano parcialmente desmineralizado após o uso in vivo de dentifrícios fluoretados. Foi realizada a microdureza superficial no esmalte hígido, após a desmineralização in vitro e após a exposição do esmalte aos tratamentos com dentifrícios in vivo durante (duas semanas). De acordo com os resultados não houve nenhuma diferença estatística entre o efeito dos dentifrícios fluoretados e os valores médios da microdureza após o experimento in vivo. Entretanto, a média do comprimento das indentações aumentou significantemente para todos os dentifrícios utilizados quando comparados ao esmalte inicialmente desmineralizado. Mas os autores concluem que entre os tipos de dentifrícios utilizados, nenhuma diferença significante foi encontrada com relação à capacidade de remineralização da superfície de esmalte sobre a placa bacteriana num período de 2 semanas.

Em 1990, ZERO ${ }^{121}$ realizou uma comparação entre o teste de microdureza superficial, permeabilidade de $\mathrm{KI}$ a $2 \mathrm{M}$ e a dissolução mineral de esmalte bovino submetido ao desafio ácido. Após o polimento dos blocos de esmalte, a microdureza inicial foi determinada nas extremidades dos blocos, 
em seguida uma camada de esmalte cobriu as indentações deixando uma área exposta para a realização do teste de permeabilidade do $\mathrm{KI}$ a $2 \mathrm{M}$. Os blocos de esmalte foram então imersos na solução de lactato a 0,05 M (pH 4,75) nos tempos 0 (controle), 5, 15, 30, 45, 60, 120 e 240 min. Para cada período, diferentes blocos foram utilizados e a análise do Ca e $\mathrm{P}$ realizada. $\mathrm{O}$ teste de permeabilidade final e a microdureza superficial final foi feito. A perda mineral encontrada para o Ca e $\mathrm{P}$ foi diretamente proporcional ao tempo de dissolução $(r=0,95)$, já as variações nos testes de permeabilidade do $\mathrm{KI}$ a $2 \mathrm{M}$ e a microdureza superficial, aumentaram linearmente de acordo com o tempo ( $r=0,60$ e 0,65, respectivamente). O índice de correlação entre os testes de permeabilidade do $\mathrm{KI}$ a $2 \mathrm{M}$ e a microdureza superficial foi de 0,55 , quando um período maior de desmineralização (60, 120 e $240 \mathrm{~min}$ ) foi incluído, o índice de correlação foi de 0,68 . Os autores concluem que ambos os testes podem ser usados como parâmetros para medir os estágios de desmineralização do esmalte.

ARENDS; TEN BOSCH${ }^{8}$, em 1992, realizaram uma revisão de literatura em que se avaliaram as técnicas capazes de quantificar a perda ou ganho mineral na superfície do esmalte e dentina em estudos in situ. Os autores concluíram que entre as técnicas disponíveis para medir as mudanças após a des-remineralização in situ, a técnica da microrradiografia transversal é capaz de medir diretamente o conteúdo mineral quantitativamente, as trocas minerais e a distribuição dos minerais na superfície dentária. Já a técnica de microdureza superficial dá informações qualitativas sobre as trocas minerais na superfície e a técnica da microdureza longitudinal (interna) mede o conteúdo mineral que pode ser usado para a avaliação quantitativa indireta, podendo também ser estimado a \% volume mineral como é determinado pela técnica de microrradiografia, sendo diretamente proporcional ao comprimento da indentação em $\mu \mathrm{m}$, com um coeficiente de correlação de 0,92, após a realização de estudos in situ que envolvem o processo de des-remineralização.

DELBEM; CURY ${ }^{29}$, em 2002, avaliaram o efeito do tempo de aplicação de géis fluoretados acidulado e neutro na incorporação de $F$ na superfície do esmalte e a resistência à desmineralização in vitro. Os blocos de esmalte humano foram submetidos à determinação da microdureza superficial e Tatiana de Almeida Furlani 
tratados com gel fluoretado acidulado ou neutro por 1 ou 4 minutos, e o grupo controle não foi tratado com nenhum gel fluoretado. Os blocos foram submetidos a um modelo de ciclagem de $\mathrm{pH}$ que simula o desafio cariogênico. Após a ciclagem de $\mathrm{pH}$, as superfícies de esmalte desmineralizado foram analisadas quanto à microdureza superficial, microdureza interna e o $F$ incorporado na sua superfície. Os resultados revelaram que o gel fluoretado acidulado formou mais $F$ na superfície do esmalte do que o gel neutro $(p<0,05)$, sendo também mais eficiente na redução da desmineralização dos blocos quando submetidos ao desafio cariogênico. O tempo de aplicação do gel fluoretado foi significante, mas este não proporcionou uma maior resistência quanto ao $\mathrm{F}$ incorporado.

Em 2003, ARGENTA et al. ${ }^{9}$ compararam o efeito de soluções com diferentes concentrações de flúor sobre a desmineralização do esmalte dentário. Os blocos de esmalte humano foram divididos em 4 grupos: água deionizada (controle), soluções com 70, 140 e 280 ppm F. Em seguida, foram submetidos a uma ciclagem de pH (desmineralização e remineralização), a alteração do esmalte foi avaliada através da análise de microdureza superficial e longitudinal. Os valores médios da porcentagem de perda de dureza superficial (\%PDS) e de perda mineral $(\Delta Z)$ apresentaram correlações negativas significativas com as concentrações de $F$ dos tratamentos (\%PDS, $r=$ -0,9048; $p<0,0001$, correlação linear/ $\Delta Z, r=-0,9858 ; p=0,0287$, correlação polinomial). Com este protocolo foi possível observar um efeito dose-resposta do F sobre a desmineralização.

Com o objetivo de avaliar a influência da solução de armazenagem na desmineralização do esmalte submetido à ciclagem de $\mathrm{pH}, \mathrm{MOURA}$ et al. ${ }^{61}$, em 2004, realizaram um estudo in vitro. Para tal, foram utilizados 60 blocos de esmalte humano ( $3^{\circ}$ molar) os quais foram divididos em 4 grupos $(n=15)$ de acordo com o tipo de armazenamento e ciclagem de $\mathrm{pH}$ : formol a $2 \%$ por 6 meses (F1), timol a $0,01 \%$ por 6 meses (T1), formol a $2 \%$ por 6 meses e ciclagem de $\mathrm{pH}(\mathrm{F} 2)$ e timol a $0,01 \%$ por 6 meses e ciclagem de $\mathrm{pH}$ (T2). Os grupos controle (F1 e T1) foram mantidos em ambiente úmido e refrigerado, enquanto os grupos (F2 e T2) foram submetidos a um modelo de ciclagem de $\mathrm{pH}$ por 5 dias, onde houve períodos alternados de des-remineralização. Todas 
as amostras foram submetidas à análise de microdureza longitudinal e tiveram a porcentagem de volume mineral determinada. Diferenças entre os grupos foram encontradas até a profundidade de $30 \mu \mathrm{m}$ da superfície do esmalte $(p<0,05)$, na qual os grupos T2 e F2 apresentaram maior e menor perda mineral, respectivamente. Os autores concluíram que a solução de armazenagem teve influência na susceptibilidade do esmalte a um desafio cariogênico

LOBO et al. ${ }^{52}$, em 2005, avaliaram o efeito da aplicação de selantes sobre a desmineralização do esmalte in vitro, focando a proteção física e química do esmalte por este tratamento. Fissuras oclusais com áreas de 12 $\mathrm{mm}^{2}$ foram delimitadas em 48 molares extraídos, que foram divididos aleatoriamente em 4 grupos ( $n=12)$ : 1 ) sem selamento; 2 ) selamento com CIV modificado por resina $\left(V_{i t r e m e r}{ }^{\circledR}\right)$; 3) selamento com selante resinoso liberador de $F\left(\right.$ Climpro $\left.^{\circledR}\right)$; 4) selamento com selante resinoso sem $F$ (Concise ${ }^{\circledR}$ ). Uma janela de $4 \mathrm{~mm}^{2}$ foi delimitada na face vestibular dos molares para análise da incorporação de $F$ através da técnica da biopsia ácida. Os grupos 2, 3 e 4 foram submetidos a uma ciclagem de $\mathrm{pH}$, durante 5 dias, enquanto o grupo 1 foi mantido em ambiente úmido a $37^{\circ} \mathrm{C}$. A desmineralização do esmalte foi avaliada por microdureza longitudinal, nas distâncias de 10, 20, 30, 40 e 50 m, $100 \mu \mathrm{m}$ acima e $100 \mu \mathrm{m}$ abaixo da margem do selante. O grupo 2 apresentou maior incorporação de flúor no esmalte em comparação aos demais grupos, bem como menor desmineralização no esmalte acima do selante, exceto nas profundidades de 30, 40 e $50 \mu \mathrm{m}$, em relação ao grupo 3. No esmalte abaixo do selante não houve diferença significativa na desmineralização entre os grupos. Não houve diferença significativa entre os grupos 3 e 4 na incorporação de flúor no esmalte, mas o grupo 3, comparativamente ao grupo 4, apresentou menor desmineralização em todos as profundidades avaliadas. Com base nos resultados, pode-se concluir que o selante que apresentou maior efeito anti-cariogênico foi o Vitremer $^{\circledR}$.

Em 2006, BRIGHENTI et al. ${ }^{17}$, realizaram um estudo in vitro para comparar o efeito da acidificação de dentifrícios com baixa concentração de $\mathrm{F}$ (412 e $550 \mu \mathrm{gF} / \mathrm{g}$ ) sobre a desmineralização do esmalte. Blocos de esmalte bovino foram divididos em 12 grupos $(n=13)$, de acordo com a concentração 
de $\mathrm{F}$ no dentifrício (placebo, 275, 412, 550 ou $1100 \mu \mathrm{gF} / \mathrm{g}$ ) e pH $(7,0$ ou 5,5), sendo utilizados mais dois dentifrícios disponíveis comercialmente: $1100 \mu \mathrm{gF} / \mathrm{g}$, $\mathrm{pH} 7,0$ (controle positivo) e dentifrício infantil $(500 \mu \mathrm{gF} / \mathrm{g}, \mathrm{pH} \mathrm{7,0).} \mathrm{Os} \mathrm{blocos}$ foram submetidos à ciclagem de $\mathrm{pH}$ por 7 dias e os tratamentos com dentifrício foram realizados 2 vezes por dia. As quantidades de $F$, Ca e $P$ foram analisadas nas soluções após a ciclagem e o esmalte foi avaliado quanto à porcentagem de alteração da microdureza superficial e perda mineral. Os dentifrícios acidificados reduziram a porcentagem de alteração da microdureza superficial, em comparação aos dentifrícios neutros, em todas as concentrações testadas. Foram encontradas maiores concentrações de $\mathrm{F} e$ menores de $\mathrm{Ca}$ e $\mathrm{P}$ nas soluções dos dentifrícios acidificados. Em relação ao $\Delta Z$, somente o controle positivo e os grupos com $1100 \mu \mathrm{gF} / \mathrm{g}$ acidificado e neutro foram estatisticamente eficazes Os dentifrícios acidificados apresentaram uma relação dose-resposta com todas as variáveis. Para os dentifrícios de baixa concentração avaliados, somente aquele com $550 \mu \mathrm{gF} / \mathrm{g}$ (acidificado) apresentou o mesmo efeito anticariogênico do dentifrício com $1100 \mu \mathrm{gF} / \mathrm{g}$ (neutro), comumente encontrado no mercado.

\subsection{Concentração de íons na placa bacteriana}

TEN CATE; DUIJSTERS ${ }^{96,97}$, em 1983, avaliaram a desmineralização em esmalte bovino submetido a diferentes concentrações de $\mathrm{F}$ e pHs. As combinações do pH (4,0 e 5,0) e a concentração de $\mathrm{F}(0$ e 10ppm) utilizadas foram determinadas pela solubilidade isotérmica do $\mathrm{CaF}_{2}$ e fluorapatita. Cerca de $20 \mathrm{~mm}^{2}$ da superfície do esmalte foram expostas a $10 \mathrm{~mL}$ das soluções durante 21 dias, seguido da posterior análise das concentrações dos íons $\mathrm{F}, \mathrm{Ca}$ e P. Quando a perda de Ca foi comparada com a perda de P em todas as soluções usadas, estas mostraram uma regressão linear independente do pH e das concentrações de $F$. A efetividade da incorporação de $F$ aumentou com a quantidade de Ca perdida durante a desmineralização. A perda de íons Ca e P do esmalte quando submetido a uma solução de desmineralização estava relacionada com as diferenças de $\mathrm{pH}$ e concentrações de $\mathrm{F}$. Em todos os casos, a perda de íons $\mathrm{Ca}$ e $\mathrm{P}$ estava associada à entrada do íon $\mathrm{F}$. A supersaturação de desmineralização com relação ao $\mathrm{CaF}_{2}$ foi mais efetiva em 
retardar o índice de desmineralização do que quando supersaturado com a fluorapatita.

PEARCE $^{69}$, em 1984 avaliou a composição mineral da placa dentária em 15 voluntários os quais utilizaram uma solução para bochecho contendo cálcio, fosfato, uréia e MFP, no $2^{\circ}, 3^{\circ}$ e $4^{\circ}$ dia, durante 4 vezes ao dia por 3 semanas. Os voluntários foram orientados a suspender os hábitos de higiene por 4 dias, mas a dieta foi mantida normalmente. No quinto dia, a placa supragengival formada sobre as superfícies vestibulares e linguais (dentes 11, 15, 21, 25, 34, 37, 44 e 47) foi coletada. Os voluntários ainda permaneceram por 3 semanas na fase que antecedeu ao bochecho com a solução e no final a placa também foi coletada. Nos dias em que os voluntários utilizaram a solução para bochecho houve um aumento significante nas concentrações de $\mathrm{Ca}, \mathrm{F}$ e $\mathrm{P}$ na placa coletada $(42,5 \mu \mathrm{g} / \mathrm{mg}, 500 \mathrm{ng} / \mathrm{mg}$ e $22,7 \mu \mathrm{g} / \mathrm{mg}$, respectivamente). 0 aumento de Ca na placa estava fortemente associado com o aumento do $\mathrm{P}$, já o aumento de $F$ foi fracamente associado ao aumento do $\mathrm{Ca}$ e $\mathrm{P}$, mas as correlações foram significantes ( $\mathrm{Ca} \times \mathrm{F} p=0,7$ e $\mathrm{P} \times \mathrm{F} p=0,66$ ), na fase em que se utilizou a solução para bochecho. Segundo o autor, o aumento da concentração de Ca na fase em que utilizou a solução para bochecho estava relacionado à concentração inicial da placa na fase que antecedeu o uso da solução.

As concentrações de $F$, Ca e $P$ inorgânico de placa dentária formada em superfícies proximais após a escovação com dentifrícios com NaF ou MFP foram determinadas por SIDI ${ }^{89}$, em 1989. O estudo cruzado e duplo-cego foi conduzido por 6 semanas que consistiu em: $1^{\circ}$ período, na $1^{\circ}$ semana os voluntários utilizaram dentifrício sem $\mathrm{F}$ e na $2^{\circ}$ semana utilizaram dentifrício com $\mathrm{F}(\mathrm{NaF}) ; 2^{\circ}$ período, na $1^{\circ}$ semana os voluntários utilizaram dentifrício sem $\mathrm{F}$ e na $2^{\circ}$ semana utilizaram dentifrício com $\mathrm{F}$ (MFP), $3^{\circ}$ período, na $1^{\circ}$ semana os voluntários utilizaram dentifrício sem $\mathrm{F}$ e na $2^{\circ}$ semana utilizaram dentifrício sem $\mathrm{F}$ mas com sílica abrasiva. No início de cada semana os voluntários ainda receberam uma profilaxia com pasta profilática sem F. No dia da coleta da placa os voluntários escovaram os dentes sob supervisão e após 1 hora a placa foi coletada das superfícies proximais de todos os dentes, exceto os dentes anteriores inferiores. Os resultados mostraram que a concentração de $\mathrm{F}$ na placa foi maior quando se utilizou o dentifrício com $\mathrm{NaF}$, já as 
concentrações de Ca e $\mathrm{P}$ inorgânico foram maiores quando os voluntários utilizaram o dentifrício com MFP. O uso de ambos os dentifrícios com $\mathrm{F}$ aumentou significantemente as concentrações de $F$ na placa dentária formada nas superfícies proximais quando comparado ao dentifrício sem $\mathrm{F}$.

A distribuição de $F$, Ca e $P$ em placa bacteriana foi determinada por KATO et al. ${ }^{44}$, em 1997 para avaliar o efeito da solução de NaF a 900 ppm. A placa bacteriana in vivo foi colhida após $10 \mathrm{~min}$ e $24 \mathrm{~h}$ seguida do bochecho com a solução de NaF a 900 ppm e após 3 dias sem o uso da solução fluoretada. A análise da placa bacteriana colhida após $10 \mathrm{~min}$, revelou um aumento significante na concentração de $F$, indicando que o $F$ penetrou facilmente no seu interior. De outra forma, as distribuições de $\mathrm{Ca}$ e $\mathrm{P}$ permaneceram baixas quando comparadas ao grupo controle (sem o uso da solução fluoretada). As concentrações de $\mathrm{F}$ na placa bacteriana após $24 \mathrm{~h}$ foram significantemente menores do que após o bochecho aos $10 \mathrm{~min}$. Os autores consideram que a solução fluoretada administrada de uma só vez, não poderia manter a concentração elevada nem mesmo por $24 \mathrm{~h}$. Entretanto, as concentrações de $\mathrm{P}$ na placa colhida após $24 \mathrm{~h}$ foram significantemente maiores que as concentrações que foram analisadas logo após.

Em 2002, WHITFORD et al. ${ }^{120}$ realizaram um estudo cruzado e duplocego envolvendo 13 indivíduos adultos que consumiam água fluoretada $(0,75 p p m$ a 1,0 ppm) para determinar a concentração de $F$ na saliva e na placa bacteriana após o uso de dentifrício fluoretado ou placebo. As amostras de saliva e placa foram coletadas 1 e 12 horas após a última exposição ao dentifrício. As concentrações de $F$ presentes na placa e saliva forma medidas após difusão facilitada por HMDS. Também foram analisadas as concentrações de Ca, Zn e Mg, por espectrometria de absorção atômica. As concentrações de F na saliva após 1 e 12 horas da escovação com o dentifrício fluoretado (24,3 e 6,6 $\mathrm{\mu mol} / \mathrm{L})$ foram significantemente maiores que aquelas associadas com o uso do placebo $(1,5 \mu \mathrm{mol} / \mathrm{L})$. A concentração de $\mathrm{F}$ na placa de 1 hora associada ao uso de dentifrício fluoretado $(22,9 \mathrm{mmol} / \mathrm{Kg}$ peso seco) foi maior que na placa de 12 horas $(12 \mathrm{mmol} / \mathrm{Kg})$ e que na placa de 1 e 12 horas após o uso do placebo $(10 \mathrm{mmol} / \mathrm{Kg})$. Porém, as concentrações de $\mathrm{F}$ na placa coletada após 12 horas não foram estatisticamente diferentes entre os dois dentifrícios. Houve uma grande variação nas concentrações de Ca e F na placa, mas a 
análise de regressão mostrou uma forte correlação entre a concentração de Ca e F na placa $(r=0,79 ; p<0,0001)$, além de uma correlação mais fraca entre a concentração de $M g$ e $F(r=0,33 ; p=0,017)$ e nenhuma correlação entre a concentração de $Z n$ e $F$ na placa $(p=0,56)$. Os autores concluíram que pessoas que tomam água fluoretada possuem uma concentração de $\mathrm{F}$ durante grande parte do dia que não é significativamente aumentada pelo uso de dentifrício fluoretado, e que essa concentração, seria mais dependente da concentração de Ca na placa, que se ligaria ao $\mathrm{F}$.

Em 2005, WHITFORD et al. ${ }^{117}$ avaliaram em um estudo in vivo duplocego e duplo-cruzado, os efeitos do uso de um dentifrício fluoretado na concentração de $\mathrm{F}$ na placa bacteriana e na saliva em uma comunidade sem $\mathrm{F}$ na água e examinaram a relação entre as concentrações de $\mathrm{Ca}$ e $\mathrm{F}$. Participaram da pesquisa 16 indivíduos, que utilizaram dentifrício fluoretado ou placebo, por 1 semana. Após 1 e 2 horas da última utilização destes produtos, a saliva e a placa foram coletadas e analisadas em relação a presença de Ca e F, por espectrometria de absorção atômica e difusão facilitada por HMDS, respectivamente. O estudo foi repetido para incluir um bochecho com Cloreto de $\mathrm{Ca}\left(\mathrm{CaCl}_{2}\right)$ em uma concentração de $20 \mathrm{mM}$ imediatamente antes do uso do dentifrício,. Os autores verificaram que este bochecho promoveu apenas pequenos aumentos nas concentrações salivares de $\mathrm{Ca}$ e $\mathrm{F}$, e nenhum efeito nas concentrações destes elementos na placa. No entanto, quando VOGEL et al. ${ }^{112}$ (2005) testaram a realização de bochechos contendo Lactato de Ca previamente a realização de um bochecho com uma solução de $\mathrm{NaF}$ (228 ppm $F$ ), obtiveram aumentos estatisticamente significativos nas concentrações de $F$ na saliva e no fluido da placa. Os resultados mostraram um aumento de 5 a 6 vezes na concentração de $\mathrm{F}$ na saliva e no fluido da placa.

VOGEL et al. ${ }^{113}$ (2006), determinaram o efeito de um pré-bochecho de Ca associado a um bochecho com $\mathrm{NaF}$ na quantidade de $\mathrm{F}$ que foi extraído por meio de tampões neutros ou ácidos da placa. Participaram deste estudo 13 voluntários que realizaram bochecho com $20 \mathrm{~mL}$ de Lactato de Ca (150 mM) por 1 minuto e em seguida, realizaram outro bochecho com $20 \mathrm{~mL}$ de NaF (228 ppm F) durante 1 minuto. Como controle, o pré-bochecho com Ca não foi realizado. Duas amostras de placa foram coletadas e seqüencialmente extraídas 5 vezes com $\mathrm{pH} 6,8$ ou tampão acetato $\mathrm{pH} \mathrm{4,8.} \mathrm{O} \mathrm{restante} \mathrm{de} \mathrm{F}$ foi Tatiana de Almeida Furlani 
determinado por meio de extração ácida. A média total de $\mathrm{F}$ para as 2 amostras de placa foi $452 \pm 50$ para o pré-bochecho de Ca associado a um bochecho com NaF e $47 \pm 7$ para o bochecho realizado apenas com $\mathrm{NaF}$. Os autores concluíram que um bochecho prévio com $\mathrm{Ca}$ antes da realização de um bochecho com NaF produziu um aumento significativo na quantidade de $\mathrm{F}$ extraído da placa total $(p<0,05)$.

Em 2006, PESSAN et al. ${ }^{73}$ analisaram as concentrações de $\mathrm{F}$ na placa bacteriana e na saliva após o uso de um dentifrício fluoretado precedido por um bochecho com Lactato de Ca. Este estudo cruzado duplo-cego testou o efeito de um bochecho com lactato de $\mathrm{Ca}(150 \mathrm{mM})$ realizado previamente à escovação com dentifrício placebo ou fluoretado (contendo 1030 ppm F como $\mathrm{NaF}$ ) nas concentrações de $\mathrm{F}$ e $\mathrm{Ca}$ presentes na placa e na saliva. Participaram deste estudo 16 crianças, com idades entre 8 e 10 anos, as quais foram igualmente distribuídas em 4 diferentes grupos de acordo com os tratamentos: dentifrício placebo ou dentifrício fluoretado precedido por bochecho com Lactato de $\mathrm{Ca}$ ou placebo (água deionizada). As coletas de placa e saliva foram realizadas no sétimo dia, após 1 e 12 horas da última escovação. A concentração de $F$ foi determinada utilizando-se o eletrodo íonespecífico e a concentração de $\mathrm{Ca}$ foi analisada por espectrometria de absorção atômica. O bochecho com Lactato de Ca não promoveu aumentos significativos nas concentrações de Ca na placa e na saliva, exceto na placa de 1 hora após escovação com dentifrício placebo. Já para a saliva, verificou-se um aumento significativo 1 hora após escovação com dentifrício fluoretado. Os autores concluíram que o bochecho com Lactato de $\mathrm{Ca}$ não afetou as concentrações de F na placa sob nenhuma condição.

\subsection{Efeito da sacarose sobre a placa bacteriana}

Em 1984, SCHEIE et al. ${ }^{86}$, testaram o efeito de uma dieta rica em sacarose na composição microbiológica e acidogenicidade da placa bacteriana. Quatro voluntários foram instruídos a não higienizar as superfícies vestibulares dos dentes posteriores inferiores direitos. Durante 3 semanas eles ingeriram uma dieta com baixa quantidade de sacarose (dieta 1) e em 3 semanas subseqüentes, uma dieta com alta quantidade de sacarose (dieta 2), que incluía a aplicação de $1 \mathrm{~mL}$ de uma solução desse açúcar a $60 \%$ na área 
estudada, 8 vezes ao dia. A contagem de S. mutans na saliva e a análise microbiológica da placa foram realizadas semanalmente, sendo sua acidogenicidade determinada ao final de 3 semanas. Os níveis salivares de $S$. mutans não foram afetados sistematicamente por nenhuma das dietas. Da mesma maneira, o número de freqüência de detecção em cada superfície foi maior durante a dieta 2. Ela também provocou uma maior queda do $\mathrm{pH}$ nos voluntários $A, B$ e $C$. $O$ voluntário $D$ apresentou os valores mais baixos de $p H$, embora não tenham sido detectados S. mutans em suas amostras de placa. Apesar de a dieta ter afetado a acidogenicidade da placa, seus efeitos sobre os parâmetros microbiológicos não foram tão uniformes. Houve uma tendência das placas contendo mais de $0,1 \%$ de $S$. mutans demonstrarem maior queda de $\mathrm{pH}$. Dois voluntários ( $\mathrm{A}$ e $\mathrm{C}$ ) apresentaram mancha branca após a dieta 2 , mas a placa no local onde ocorreram não demonstrou características peculiares quanto à microbiota e à acidogenicidade da placa. Níveis salivares altos de $S$. mutans foram mais freqüentes nos voluntários ( $A$ e $B$ ), que também apresentaram o maior número de sítios dentários infectados. Entretanto, o voluntário D possuía níveis de S. mutans mais altos que o voluntário C $(5000 \mathrm{e}$ 500 UFC/mL, respectivamente), mas não demonstrou crescimento dessa bactéria em suas amostras de placa.

Em 1997, CURY; REBELLO; DEL BEL CURY ${ }^{28}$ avaliaram a composição da placa bacteriana de acordo com a exposição à sacarose. Doze voluntários participaram de um estudo in situ cruzado, feito em quatro fases distintas de 28 dias, nas quais um aparelho de acrílico palatino foi construído para cada voluntário. Em cada dispositivo foram fixados quatro blocos de esmalte humano protegidos por uma tela plástica. Durante as fases, os voluntários gotejaram uma solução de sacarose a $20 \%$, variando o número de aplicações por dia $(0$, 2, 4 e 8), utilizaram dentifrício sem $\mathrm{F}$ e beberam água com 0,7 ppm de F. Após cada fase, foram determinadas as concentrações de $\mathrm{F}, \mathrm{Ca}, \mathrm{P}$ e carboidratos totais na placa bacteriana. A análise estatística mostrou que aplicações freqüentes de sacarose reduziram significantemente as concentrações de $F$, Ca e $\mathrm{P}$ na placa, mas aumentaram a concentração de carboidratos álcalisolúveis. Os resultados sugerem que a cariogenicidade da placa bacteriana formada na presença de sacarose não pode ser atribuída somente à sua alta porosidade, mas a baixa concentração inorgânica também é importante. 
A liberação de íons na placa bacteriana após a produção de ácidos foi investigada por TANAKA, MARGOLIS ${ }^{91}$ (1999). Após 48 horas sem escovação e jejum anterior à noite da coleta, a placa supragengival formada foi coletada em voluntários de todas as superfícies (exceto os incisivos inferiores). Primeiramente os voluntários realizaram um bochecho com água e a placa foi coletada em metade da boca, em seqüência os voluntários bochecharam uma solução de sacarose a 292 mM e a placa foi coletada da outra metade da boca. Quando os voluntários se submeteram ao bochecho com a sacarose, o $\mathrm{pH}$ do

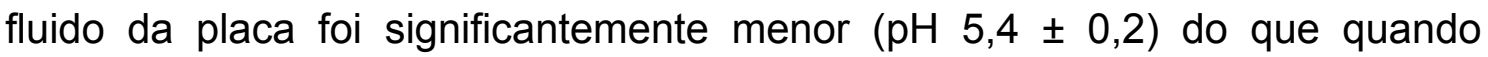

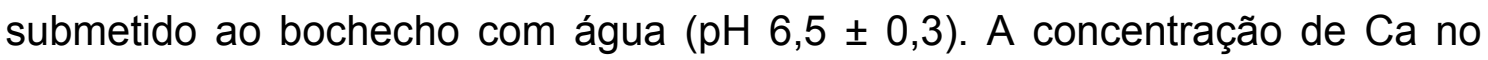
fluido da placa foi significantemente maior após a exposição à sacarose $(0,046$ $\mathrm{mg} / \mathrm{g} \pm 0,006)$ do que a exposição à água $(0,013 \mathrm{mg} / \mathrm{g} \pm 0,002)$, o mesmo com a concentração de $P(0,275 \mathrm{mg} / \mathrm{g} \pm 0,050)$ quando exposto à sacarose. Tanto na exposição à sacarose quanto à água nenhuma diferença foi encontrada para a concentração de $F(0,023 \pm 0,010, p<0,05)$.

CURY et al. ${ }^{26}$, em 2000, analisaram a composição da placa na presença de sacarose ou glicose e frutose em um estudo in situ. Durante 8 vezes por dia os voluntários removeram os dispositivos acrílicos e gotejavam as soluções de sacarose a $20 \%$ ou de glicose a $10 \%$ + frutose a $10 \%$ cada nos fragmentos de esmalte por 28 dias. Como grupo controle nenhuma solução foi utilizada. Após 12 horas da última exposição às soluções de cada fase, a placa bacteriana formada sobre os blocos foi coletada e analisada. As concentrações de F, P, Ca e proteínas foram significantemente menores na placa bacteriana formada na presença de sacarose do que em relação ao grupo controle $(p<0,05)$. Mesmo sendo valores numericamente mais baixos para o grupo que gotejou a solução de sacarose, o grupo não alcançou uma significância estatística em relação ao grupo que gotejou a solução de glicose + frutose. Houve um aumento significante na concentração de carboidratos álcali-solúveis quando a placa bacteriana foi formada na presença de sacarose. Na avaliação clínica dos blocos, 90\% deles exibiram lesões de mancha branca para o grupo exposto à sacarose contra $56 \%$ para o grupo exposto à glicose + frutose. Mudanças na microdureza de superfície também foram observadas para o grupo submetido à sacrose $(p<0,05)$. Houve diferença significante na concentração de $F$ na superfície do esmalte entre os tratamentos $(p<0,05)$, os 
grupos sacarose e glicose + frutose apresentaram maiores quantidades de $\mathrm{F}$ no esmalte quando comparados ao grupo controle.

Em 2001, CURY et al. ${ }^{27}$ avaliaram o efeito anticariogênico do dentifrício com uma associação de $\mathrm{F}$ e bicarbonato de sódio, comparando com um dentifrício somente com $\mathrm{F}$, em um estudo in situ cruzado, realizado em três fases de 28 dias. Dez voluntários utilizaram dispositivos acrílicos intrabucais palatinos removíveis. Contento quatro blocos de esmalte humano polidos previamente, sendo dois hígidos (para avaliar a desmineralização) e dois desmineralizados in vitro (para avaliar a remineralização). Estes blocos foram montados abaixo do nível da resina e foram protegidos com uma tela plástica para acúmulo de placa bacteriana. Durante cada fase, uma solução de sacarose a $10 \%$ foi gotejada nos blocos hígidos, três vezes ao dia. Após 10 minutos, em cada fase experimental, uma solução de dentifrício foi gotejada sobre todos os blocos: 1) placebo (sem F e sem bicarbonato de sódio); 2) com F (1500 ppm, NaF); 3) com F (1500 ppm, NaF) mais bicarbonato de sódio a $20 \%$. Foram realizadas análises da concentração de $\mathrm{F}$ na plca bacteriana coletada e da microdureza longitudinal do esmalte. Os resultados mostraram uma alta concentração de $F$ na placa formada nos grupos 2 e 3 , que não diferiram entre si, em relação ao $1(p<0,05)$. A desmineralização foi menor e a remineralização foi maior no grupo 3 , quando comparado ao $1(p<0,05)$, mas a diferença em relação ao grupo 2 não foi significante tanto na remineralização como na desmineralização. O grupo 2 apresentou remineralização estatisticamente superior ao 1, mas não foram diferentes na desmineralização. Os dados sugerem que o bicarbonato de sódio não auxilia e nem ajuda o efeito do dentifrício fluoretado na redução da desmineralização e na melhora da remineralização do esmalte.

A relação entre a freqüência da aplicação de sacarose e as concentrações de Ca e $\mathrm{P}$ inorgânico foram analisados por PEARCE et al. ${ }^{70}$, em 2002, em um sistema de cultura de placa criada em boca artificial. Dez placas cresceram simultaneamente através da inoculação de saliva humana utilizando um simulador de fluxo salivar contínuo, suplementado com uréia ou glicose para modular os intervalos de $\mathrm{pH}$. Dentro de cada grupo de placa, uma não recebeu sacarose, as outras receberam sacarose a $10 \%$ durante 6 minutos em intervalos de 12, 8, 6 e 4 horas, por um período de 15 dias. Quando as 
amostras de placa receberam o suplemento com uréia foi encontrado um aumento significante nos valores das concentrações de Ca e P inorgânico do que quando suplementado com glicose, mas o efeito foi particularmente pronunciado na placa que não recebeu sacarose. A freqüência da aplicação da sacarose teve um efeito significante na concentração de Ca e P inorgânico, entretanto a concentração de $\mathrm{Ca}$ foi fortemente correlacionada com a freqüência de aplicação da sacarose quando suplementada com uréia ( $r=$ 0,93, $p<0,001)$ e com glicose $(r=-0,86, p<0,001)$. A concentração de $P$ inorgânico foi fracamente correlacionada com a freqüência da aplicação da sacarose suplementada com uréia $(r=-0,64, p=0,003)$ e com glicose $(r=-0,47$, $p=0,04)$. O freqüente consumo de açúcar pode tornar a placa bacteriana insaturada em relação ao cálcio e fósforo, facilitando a desmineralização dentária.

Em 2006, Aires et al. ${ }^{1}$ avaliaram a relação entre a concentração de sacarose e potencial cariogênico, em um estudo in situ cruzado e duplo-cego, que envolveu a participação de 12 voluntários adultos. Os participantes utilizaram dispositivos palatinos removíveis com quatro blocos de esmalte humano, fixados $1 \mathrm{~mm}$ abaixo do nível da resina acrílica e protegidos por uma tela plástica para acúmulo de placa bacteriana. Este estudo foi desenvolvido em três etapas de 14 dias cada, avaliando a resposta obtida pela aplicação extrabucal dos tratamentos (água destilada e deionizada - ADD, solução de sacarose a $1 \%, 5 \%, 10 \%, 20 \%$ ou $40 \%$ ) oito vezes por dia. Em cada fase experimental dois tratamentos foram testados. Ao final dos períodos foram avaliados $\mathrm{o} \mathrm{pH}$, a composição inorgânica e o conteúdo de polissacarídeos insolúveis (PI) do biofilme formado sobre os blocos, além da microdureza do esmalte. Os resultados mostraram que os menores níveis de $\mathrm{pH}$ após 5 minutos de exposição à sacarose foram obtidos com as soluções a 10, 20 e $40 \%$, sem diferenças significativas entre estas concentrações. A solução a $5 \%$ apresentou $\mathrm{pH}$ maior que a de $40 \%$, mas não diferiu das soluções de 10 ou $20 \%$. As maiores concentrações de $F$ foram encontradas nos grupos ADD e sacarose a $1 \%$, que não diferiram estatisticamente entre si, mas foram significativamente maiores que os grupos que receberam sacarose a 10, 20 e $40 \%$. A concentração de $F$ encontrada com a solução a $5 \%$ foi estatisticamente diferente da solução a 40\%. As concentrações de Ca e P nos grupos ADD e 
sacarose a $1 \%$ não diferiram entre si, mas foram estatisticamente superiores do que os outros tratamentos. Os outros grupos não apresentaram diferenças significativas entre si em relação à concentração de $\mathrm{P}$. A concentração de PI foi estatisticamente menor no grupo ADD do que nos outros grupos. Os grupos da sacarose a 5, 10 e 20\% não diferiram entre si, mas apresentaram estatisticamente maiores concentrações de PI que a sacarose a $1 \%$ e menores concentrações que a sacarose a $40 \%$. Os autores concluíram que a concentração de sacarose limiar para a formação de uma placa bacteriana com propriedades acidogênicas e com composição bioquímica capaz de promover a cárie dentária é a partir de $5 \%$.

\subsection{Efeito do bochecho de Ca no esmalte e na placa bacteriana}

Muitos relatos publicados desde os anos de 1960, revisados por TATEVOSSIAN $^{92}$ em 1990, encontraram concentrações de $F$ na placa bacteriana cerca de 100 vezes maiores que na saliva. Através de análises bioquímicas, podem ser identificadas 3 formas de $F$ na placa bacteriana: $F$ iônico (ou livre), ionizável e fortemente unido à placa (OPHAUG et al. ${ }^{67}, 1987$ ). O F iônico é a fração presente na fase aquosa extracelular da placa, conhecida como fluido da placa, quando a mesma está em repouso, ou seja, não metabolizado $(\mathrm{pH} 7,0)$. O F ionizável é a fração liberada sob acidificação durante o metabolismo bacteriano ou quando da adição de um ácido exógeno (frio), enquanto que o $\mathrm{F}$ fortemente ligado à placa apenas é liberado sob digestão em ácido aquecido ou após calcinação (WHITFORD ${ }^{118}$, 1996; WITFORD et al. $\left.{ }^{120}, 2002\right)$.

A grande importância do fluido da placa no mecanismo de ação do $F$ deve-se ao fato de que o mesmo entra em contato direto com o esmalte dentário, com a saliva e com as bactérias da placa. Este contato direto permite o estabelecimento de um estado de equilíbrio entre os níveis de $\mathrm{F}$ encontrados nestes locais após a aplicação de um agente fluoretado (RØLLA; EKSTRAND $^{78}$, 1996). VOGEL; CAREY; EKSTRAND ${ }^{104}$, 1992 demonstraram a existência de uma relação direta entre as concentrações de $F$ no fluido da placa e na saliva após a aplicação de uma solução para bochecho fluoretado, 
embora a saliva seja muito menos concentrada. Em outros estudos com bochechos fluoretados, uma relação direta também foi encontrada entre os níveis de $\mathrm{F}$ na placa e no fluido da placa, sendo este último menos concentrado que o biofilme (VOGEL et al. ${ }^{110}$, 1992). Demonstrou-se ainda que este equilíbrio persistiu mesmo após $12 \mathrm{~h}$ da realização do bochecho (VOGEL et al. $\left.^{111}, 1997\right)$.

Embora os níveis de $F$ no fluido da placa ( $F$ ionizado) sejam considerados altos em relação aos da saliva, estes correspondem a menos de $5 \%$ do total de $\mathrm{F}$ na placa, sendo que a maior parte está na forma ionazável (VOGEL et al. ${ }^{109}$, 2000). Como o $\mathrm{F}$ ionizável pode se tornar disponível (ionizado) para o meio bucal em situações de queda de pH (VOGEL et al. ${ }^{107}$, 2002), ou seja, durante um desafio cariogênico, esta fração exerce um papel importante na ação do $\mathrm{F}$ no controle de cárie dentária. $O$ fluido da placa transporta ácidos orgânicos, bem como F, Ca e fosfato e outros íons para a superfície do esmalte. Portanto, o fluido da placa é o sítio no qual o F influencia os processos de des e remineralização (EKSTRAND; SPAK; VOGEL ${ }^{33}, 1990$ ).

A fração de $\mathrm{F}$ fortemente ligado à placa bacteriana pode ser removida após ingestão em ácido aquecido, por calcinação seca ou por técnicas de combustão como a "bomba de oxigênio". O envolvimento desta fração na cariostase é duvidoso, uma vez que parece improvável que tal fração torne-se disponível numa forma iônica no fluido da placa. A possibilidade de troca limitada entre "o pool" de $F$ fortemente ligado à placa e as outras formas, entretanto, ainda não foi investigada (WHITFORD et al. $\left.{ }^{118}, 1996\right)$.

Em 1992 e em 2000, VOGEL et al. ${ }^{109,110}$ demonstraram que, após o uso de bochechos fluoretados, os níveis de $\mathrm{F}$ na saliva eram semelhantes aos valores basais, enquanto que as concentrações na placa e no fluido da placa permaneciam elevadas, indicando que algum componente da placa tem a propriedade de reter $\mathrm{F}$.

Assim como na saliva, o fluido da placa é supersaturado com relação a vários sais de Ca e fosfato de Ca amorfo (SHELLIS; DUCKWORTH ${ }^{87}$, 1994; LARSEN; PEARCE ${ }^{50}$, 2003). Estes sais localizam-se principalmente nos 
espaços extracelulares da placa, sendo que os mesmos podem fazer ligações iônicas com o $\mathrm{F}$, embora com diferentes afinidades. O $\mathrm{F}$ pode se adsorver à superfície destes compostos, mas o principal modo de interação é através da conversão de fluoreto de $\mathrm{Ca}$, hidroxifluorapatita e fluorapatita. Entretanto, com base na solubilidade destes compostos, muito provavelmente o sal formado é o fluoreto de $\mathrm{Ca}\left(\mathrm{Ca} \mathrm{F}_{2}\right.$ ) ou fluoreto de Ca-"like" (Ca $\mathrm{F}_{2}$-"like") (ARENDS; CHRISTOFFERSEN ${ }^{5}, 1990$; VOGEL et al. $\left.{ }^{108}, 2001\right)$, além de outros cátions bi e tri-valentes (WHITFORD et al. $\left.{ }^{118}, 1996\right)$.

Além dos sais de $\mathrm{Ca}$ presentes principalmente nos espaços extracelulares, a retnção de $\mathrm{F}$ na placa pode estar associada à superfície das bactérias (ROSE et al. $\left.{ }^{79,81,82,83}, 1993 ; 1996 ; 1997 ; 1998\right)$. Estas superfícies representam uma área de retenção muito grande, com cargas negativas e grupos fosfatos e carboxílicos abundantes. Grande parte do Ca presente na placa está fixado à superfície bacteriana por ligações com grupos acídicos, através de ligações bivalentes. Quando há disponibilidade do $F$ na saliva, o mesmo entra na placa e rompe uma das ligações do Ca com a superfície bacteriana, fixando-se a esta valência livre do $\mathrm{Ca}$, através da formação de $\mathrm{CaF}^{+}$. Assim, na presença do $\mathrm{F}$, existe a ligação de um grupamento ácido na superfície bacteriana, o qual poderá receber mais compostos $\mathrm{CaF}^{+}$formados na saliva após a utilização de produtos fluoretados. Este $F$ será liberado posteriormente quando houver uma queda de $\mathrm{pH}$ ou por ação do fluxo salivar. Estes processos estão esquematizados na figura 1. Em adição, o $\mathrm{F}$ pode se associar a várias moléculas orgânicas produzidas pelas bactérias presentes na placa, como o ácido lipoteicóico (ROSE et al. ${ }^{80}$, 1994).

Baseados na hipótese de que aumentos nas concentrações de Ca na placa poderiam produzir um aumento na capacidade de retenção do $\mathrm{F}$ no mesmo, CHOW; TAKAGI ${ }^{24}, 1991$ desenvolveram um bochecho em duas soluções com o objetivo de se aumentar à deposição de $\mathrm{CaF}_{2}$ sobre o esmalte. Quando as soluções $A$ e $B$ do bochecho são misturadas, os íons $F$ são liberados por hidrólise controlada do $\mathrm{SiF}_{6}{ }^{2-}$ (contido na solução $B$ do bochecho com $\mathrm{Na}_{2} \mathrm{SiF}_{6}$ ), os quais reagem com $\mathrm{Ca}^{2+}$ (presente na solução $\mathrm{A}$ do bochecho com $\mathrm{CaCl}_{2}$ ) durante o tempo de aplicação de $1 \mathrm{~min}$. $\mathrm{O}$ uso desta solução num estudo in vitro resultou em uma deposição de $\mathrm{F}$ sobre o esmalte 15 vezes 
maior que o uso de uma solução convencional de $\mathrm{NaF}$ contendo a mesma concentração de F (CHOW; TAKAGI ${ }^{24}$, 1991). Em teoria, o uso desta formulação de bochecho permite uma penetração profunda dos íons $\mathrm{Ca}^{2+} \mathrm{e}$ $\mathrm{SiF}_{6}{ }^{2-}$ nos poros dentários, na placa e na mucosa antes de sua hidrólise, com posterior formação de $\mathrm{CaF}_{2}$ (CHOW; TAKAGI ${ }^{24}$, 1991; CHOW; TAKAGI; $\mathrm{SHIH}^{25}$, 1992; VOGEL et al. $\left.{ }^{107,108,109,110,111}, 1992 ; 1997 ; 2000 ; 2001 ; 2002\right)$.

Tentativas de se aumentar à incorporação de $\mathrm{F}$ na placa bacteriana, utilizando um bochecho prévio com solução contendo cálcio, foram feitas por WHITFORD et al. ${ }^{117}$ 2005; PESSAN et al. ${ }^{73}$ 2006; VOGEL et al. ${ }^{112,113} 2005$; 2006. 

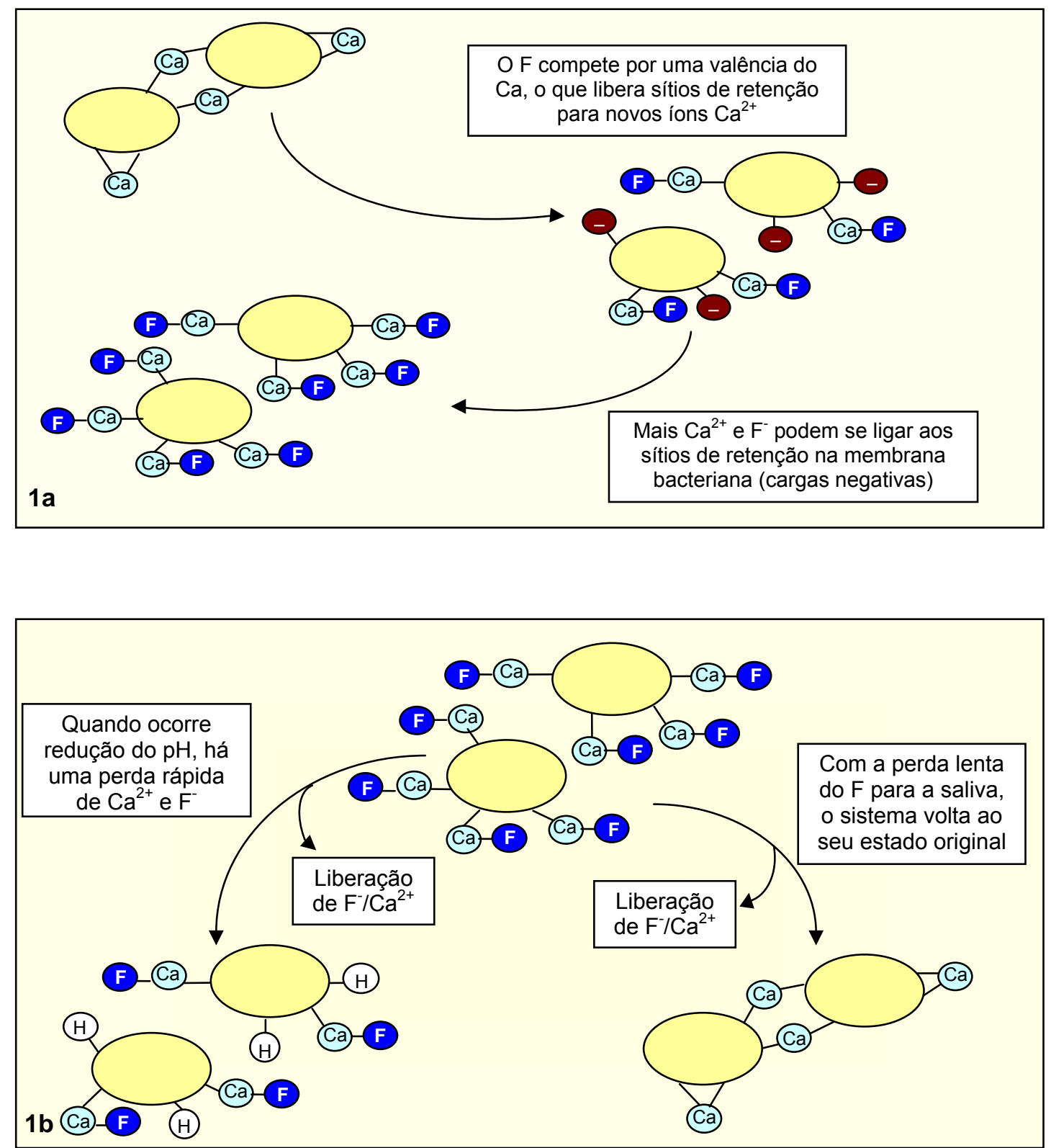

FIGURA 1 - a. Esquema proposto para a retenção de $\mathrm{F}$ à parede bacteriana, mediada por íons Ca; b. retirada do F e liberação para o meio bucal

Fonte: ROSE et al. ${ }^{81}$, 1996, modificado por Pessan, 2005.

\subsection{Determinação de $F$ no esmalte}

O método para determinar o $\mathrm{F}$ incorporado na superfície do esmalte, chamado de biópsia pode ser empregado para determinar as relações entre o nível de $\mathrm{F}$ no esmalte e a susceptibilidade à cárie ou investigar a deposição de F ingeridos ou aplicados topicamente. Com este objetivo, BRUDEVOLD; McCANN; GR $\varnothing N^{18}$, em 1968, avaliaram na camada externa do esmalte entre 1-2 $\mu \mathrm{m}$ os níveis de $\mathrm{F}$ em diferentes indivíduos. A superfície dos dentes foi 
inicialmente polida por 40-60 segundos para a remoção de uma camada de esmalte uniforme. As partículas de esmalte removidas durante o polimento foram coletadas em cones embebidos em glicerina ou com pasta abrasiva com glicerina e depositadas em tubos plásticos. Foi adicionado $1 \mathrm{~mL}$ de $\mathrm{HClO}_{4}$ 0,5 $\mathrm{M}$ ao tubo com amostras durante 1 hora, com propósito de dissolver o esmalte presente, mais $4 \mathrm{~mL}$ de citrato de sódio $0,5 \mathrm{M}$ foi adicionado e feita a agitação. No sobrenadante da cada amostra, as concentrações de F e Ca foram determinadas, pelo eletrodo de $\mathrm{F}$ e absorção atômica respectivamente. Os resultados mostraram que os níveis de $\mathrm{F}$ em dentes anteriores intactos foram muito similares no mesmo paciente, mas as concentrações médias variaram de 400 a 2500 ppm entre os diferentes pacientes do estudo. Quando uma segunda biópsia foi realizada na mesma superfície dental, a concentração de $\mathrm{F}$ foi menor que a primeira biópsia.

VOGEL; CHOW; BROWN ${ }^{105}$, em 1983, realizaram dois procedimentos diferentes para a realização da biópsia. O primeiro foi da fita adesiva com uma área central delimitada para a remoção de $10 \mu \mathrm{L}$ de $\mathrm{HClO}_{4}$ na superfície de esmalte. O ácido foi colocado com uma micropipeta durante 15 segundos sem nenhuma agitação sob a superfície, o conteúdo aspirado com a mesma micropipeta foi transferido para microtubos. A superfície do esmalte condicionada foi lavada com $10 \mu \mathrm{L}$ de água destilada durante 15 segundos, 0 conteúdo foi aspirado e adicionado ao conteúdo retirado anteriormente, onde foram adicionados mais $20 \mu \mathrm{L}$ de TISAB. O segundo método empregado foi o da imersão, onde a superfície inteira do esmalte foi submetida ao ataque do ácido. A superfície de esmalte foi introduzida dentro de tubos contendo $200 \mu \mathrm{L}$ de $\mathrm{HClO}_{4}$ 0,25 $\mathrm{M}$ e estes foram agitados por $15 \mathrm{seg}$. Após a agitação o esmalte foi retirado e colocado em novos tubos repetindo o mesmo procedimento de acordo com o número de camadas removidas. As concentrações de $\mathrm{Ca}$ e $\mathrm{P}$ foram determinadas pelo método de espectrofotometria, para as concentrações de $\mathrm{F}$ por um minieletrodo de $\mathrm{F}$ e um eletrodo adaptado que realiza numerosas leituras rapidamente. Para o método da fita adesiva, as análises das amostras de $\mathrm{Ca}$ e $\mathrm{P}$ foram determinadas em duplicata, a diferença média entre as análises das duplicatas foi de $2 \%$. As concentrações médias de Ca e P obtidas entre todas as amostras foram $3,9 \times 10^{-3} \mathrm{M}$ e 2,27 $\times 10^{-3} \mathrm{M}$, respectivamente. 
Para as concentrações de $\mathrm{F}$, as diferenças médias entre as amostras foram de 3\%. Quando o método da imersão total da amostra foi empregado, a análise do $\mathrm{F}$ foi realizada somente pelo minieletrodo, os valores médios para o $\mathrm{Ca}$ e $\mathrm{F}$ foram de aproximadamente $3,67 \times 10^{-3} \mathrm{M}$ e $1,75 \times 10^{-3} \mathrm{M}$, respectivamente. As concentrações de $\mathrm{F}$ foram calculadas sob a suposição de que o conteúdo de Ca no esmalte de rato é de $34 \%$ e o conteúdo de $\mathrm{P}$ em dente humano é de $17,4 \%$ para os 2 métodos de biópsia estudados.

O perfil do $F$ na superfície de esmalte bovino des-remineralizado foi investigado por uma nova técnica de biópsia abrasiva com ácido por IYER et al. ${ }^{43}$, em 1983. Os blocos de esmalte foram polidos e cobertos com cera exceto uma área de $0,25 \mathrm{~cm}^{2}$ na superfície vestibular, e submetidos ao processo de desmineralização por um período de 6 horas e em seguida ao processo de remineralização por 24 horas. Após a des-remineralização, as superfícies foram lavadas com água bi-destilada e secas, uma fita adesiva foi colada na superfície remineralizada com uma área exposta de $0,20 \mathrm{~cm}^{2}$. As superfícies de esmalte foram então submetidas à biópsia abrasiva e a biópsia abrasiva com ácido $\left(\mathrm{HClO}_{4}\right.$ 0,5 M) para determinar as concentrações de $\mathrm{P}, \mathrm{F}$ e $\mathrm{Ca}$. As concentrações de $\mathrm{F}$ diminuíram com $\mathrm{O}$ aumento da profundidade. $\mathrm{A}$ porcentagem de remineralização foi definida pelo índice de porcentagem de $\mathrm{Ca}$ presente em uma determinada profundidade atingindo um valor máximo de 71$77 \%$, que diminuiu com o aumento da profundidade. Ambas as técnicas de biópsia mostraram uma remineralização muito uniforme e um perfil similar foi obtido, mas as profundidades das camadas removidas não mostraram um padrão uniforme. Uma profundidade de $75 \mu \mathrm{m}$ foi alcançada com 20 biópsias abrasivas consecutivas, enquanto somente 8 com a biópsia abrasiva empregada com ácido.

A densidade mineral de lesões em esmalte foi avaliada por IKEMI; KOULOURIDES ${ }^{41}$, em 1988, através da biópsia abrasiva. Blocos de esmalte bovino foram cortados, polidos, preparados e divididos para estudo da seguinte forma: grupo 1 - esmalte hígido; grupo 2 - esmalte com lesões pré-formadas em solução tampão de lactato por 16 horas; grupo 3 - esmalte com lesões préformadas em solução tampão de lactato por 16 horas mais 7 dias em solução ácido resistente; grupo 4 - esmalte com lesões pré-formadas em solução 
tampão de lactato por 16 horas mais 7 dias em in situ com desafio cariogênico (os dispositivos foram imersos em solução de sacarose a $3 \%$ e em uma solução fluoretada 1000 ppm, 2 vezes ao dia) e ainda os blocos de esmalte foram submetidos a mais 7 dias em solução ácido-resistente. Ao final do experimento os blocos de esmalte da etapa in situ foram avaliados pelos testes de microdureza, microrradiografia e biópsia. O teste de microdureza superficial foi utilizado para medir o esmalte inicialmente, após a formação das lesões, após o período in situ e após $01^{\circ}, 3^{\circ}$ e $7^{\circ}$ dia do teste de resistência ácida. Os resultados da microdureza superficial indicaram a média e o desvio padrão da penetração das indentações. Para o grupo 1 foram $5,33 \pm 0,19$, para o grupo 2 foram 10,74 \pm 0,54 (houve um aumento de 5,40 \pm 0,58 dos valores iniciais), para o grupo 3 causou um aumento na penetração da indentação de 30,13 \pm 4,71 para $35,37 \pm 4,65$, enquanto que para o grupo 4 resultou em uma penetração da indentação de 9,54 $\pm 2,21$, houve uma redução de 2,09 \pm 1,53, sugerindo uma remineralização. O mesmo não pôde ser observado na microrradiografia. A densidade mineral média e desvio padrão encontrados na realização da biópsia para o grupo 1 foi de $2,57 \pm 0,2$. Os grupos 2 e 3 mostraram aumento da densidade mineral em direção ao esmalte não tratado, enquanto que para o grupo 4 houve uma diminuição da densidade após atingir um pico de $30 \mu \mathrm{m}$ da superfície do esmalte.

Dois estudos realizados por CASLAVSKA et al. ${ }^{20}$, em 1991, avaliaram a quantidade de $\mathrm{CaF}_{2}$ em biópsias abrasivas de esmalte após tratamento com solução fluoretada. $\mathrm{O} 1^{\circ}$ estudo avaliou os efeitos da aplicação do $\mathrm{NH}_{4} \mathrm{~F}$ ou $\mathrm{NaF}$ em adolescentes em uma comunidade com água de abastecimento fluoretada. Inicialmente foi realizada uma profilaxia e a biópsia obtida para determinar a concentração de $F$ inicial em cada adolescente, em seguida os dentes foram condicionados com $\mathrm{H}_{3} \mathrm{PO}_{4}$ 0,05 M por 1 min. Após o ataque ácido, metade dos voluntários receberam uma aplicação de uma solução de $\mathrm{NaF}$ 0,62 $\mathrm{M}$ e a outra metade uma solução de $\mathrm{NH}_{4} \mathrm{~F}$ 0,62 M, durante 3 min. Passadas 6 semanas, uma nova série de biópsias foram realizadas nos dentes submetidos às aplicações tópicas das soluções fluoretadas. No $2^{\circ}$ estudo novos adolescentes de uma comunidade em que havia deficiência de $F$ na água de abastecimento receberam 3 aplicações tópicas semestrais de $\mathrm{NH}_{4} \mathrm{~F}$ 0,62 M (3 min) precedidas de condicionamento com $\mathrm{H}_{3} \mathrm{PO}_{4}$ 0,05 M (1 min) ou 
uma solução placebo. Dezoito meses após os tratamentos, uma nova série de biópsias foi realizada nos dentes submetidos às aplicações tópicas das soluções fluoretadas. As biópsias foram analisadas por $\mathrm{KOH}$-solúvel $\left(\mathrm{CaF}_{2}\right)$ e $\mathrm{KOH}$-insolúvel ( $\mathrm{F}$ na apatita). As comparações para o teste $\mathrm{t}$ pareado no período teste de 6 semanas indicando os níveis de $F$ resultaram em uma aumento significante $\left(p=0,0003 \mathrm{NaF}\right.$ e $\left.p=0,0001 \mathrm{NH}_{4} \mathrm{~F}\right)$ da concentração inicial. $A$ quantidade de $F$ depositada sobre $\mathrm{o}$ esmalte quando foi realizado 0 tratamento com $\mathrm{NH}_{4} \mathrm{~F}$ (concentração média 84,723 ppm) indicou uma formação substancial de $\mathrm{CaF}_{2}$, enquanto o tratamento com $\mathrm{NaF}$ resultou em uma concentração média de 7,818 ppm no período de 6 semanas. No estudo de 18 meses, os valores médios para o $F$ total foram 1669 e 2085 ppm para os grupos placebo e tratados com $\mathrm{NH}_{4} \mathrm{~F}$, respectivamente. Os valores médios de $\mathrm{F}$ correspondentes as biópsias analisadas com $\mathrm{KOH}$-insolúvel ( $\mathrm{F}$ na apatita) foram de 1467 e 1731 ppm e quando analisadas com KOH-solúvel $\left(\mathrm{CaF}_{2}\right)$ foram de 202 e 354 ppm para os grupos placebo e tratados com $\mathrm{NH}_{4} \mathrm{~F}$, respectivamente. Os autores que uma quantidade muito considerável de $\mathrm{CaF}_{2}$ permanece no esmalte após 6 semanas de tratamento e que uma pequena quantidade pode permanecer no esmalte ao longo dos 18 meses após o tratamento.

A absorção de $\mathrm{F}$ em esmalte após uso de diferentes marcas comerciais de dentifrício foi testada através da biópsia por ITTHAGARUN; WEI ${ }^{42}$, em 1996. Inicialmente foi analisada a concentração de $\mathrm{F}$ dos diferentes dentifrícios. As superfícies vestibular e lingual de dentes humanos foram destinadas à realização da biópsia, onde uma fita adesiva com uma área central de aproximadamente $4,9 \mathrm{~mm}^{2}$ foi colada em cada superfície, em seguida os dentes foram totalmente cobertos com um verniz e a fita adesiva retirada. As superfícies foram expostas ao sobrenadante dos dentifrícios (anteriormente diluídos em água deionizada) durante 1 hora. Após este período, os dentes foram lavados com água deionizada, e aplicada à técnica da biópsia pela dissolução ácida, com $\mathrm{HClO}_{4}$ 0,5 $\mathrm{M}$ por $30 \mathrm{seg}$. As concentrações de $\mathrm{F}$ foram determinadas pelo eletrodo íon específico. As concentrações médias de $\mathrm{F}$ para a $1^{\circ}$ camada foram para o grupo 1 - controle: $2692 \pm 225$; dentifrício com 330 ppm F: $3245 \pm$ 188; dentifrício com 640 ppm F: $3904 \pm 282$; dentifrício com 1590 ppm F: $5341 \pm 499$. Para o grupo 2 - controle: $2380 \pm 93$; dentifrício com 
10 ppm F: 2374 土 69; dentifrício com 20 ppm F: 2766 土 192; dentifrício com 940 ppm F: $3052 \pm 164$. A concentração média de $F$ entre os grupos 1 e 2 caiu consideravelmente na $2^{\circ}$ e $3^{\circ}$ camadas, embora os níveis de $\mathrm{F}$ fossem semelhantes. 
3 Proposição 
50 Proposição 


\section{Proposição}

Este estudo cruzado e duplo-cego in situ se propôs a analisar o efeito do bochecho com lactado de cálcio previamente à utilização de dentifrício fluoretado na redução da desmineralização e no aumento da remineralização do esmalte dental bovino, bem como na composição iônica da placa bacteriana formada sobre este esmalte. As hipóteses nulas testadas foram:

1- A utilização de dentifrício fluoretado não altera o grau de desmineralização do esmalte dental bovino hígido submetido a uma situação de desafio cariogênico in situ, a composição iônica da placa bacteriana formada sobre este esmalte e nem a quantidade de F álcalisolúvel no esmalte;

2- A utilização de dentifrício fluoretado não altera o grau de remineralização in situ do esmalte dental bovino com lesão de cárie inicial, a composição iônica da placa bacteriana formada sobre este esmalte e nem a quantidade de F álcali-solúvel no esmalte;

3- A realização de um bochecho com lactato de cálcio previamente à utilização do dentifrício fluoretado não altera o grau de desmineralização do esmalte dental bovino hígido submetido a uma situação de desafio cariogênico in situ, a composição iônica da placa bacteriana formada sobre este esmalte e nem a quantidade de F álcali-solúvel no esmalte;

4- A realização de um bochecho com lactato de cálcio previamente à utilização do dentifrício fluoretado não altera o grau de remineralização in situ do esmalte dental bovino com lesão de cárie inicial, a composição iônica da placa bacteriana formada sobre este esmalte e nem a quantidade de F álcali-solúvel no esmalte. 
52 Proposição 


\section{Material Métodos}





\section{Material e Métodos}

\subsection{Aspectos Éticos}

Este projeto foi desenvolvido após ter sido submetido e aprovado pelo Comitê de Ética em Pesquisa da FOB - USP, conforme números 05/2004 e 30/2006, recebendo pareceres favoráveis (Anexos 1 e 2). Após a aprovação pelo CEP, houve um primeiro encontro com os participantes, com a finalidade de se esclarecer os objetivos e a metodologia empregada no estudo, bem como orientá-los sobre a necessidade de seguir o protocolo corretamente. Ficou claro que a qualquer momento os voluntários poderiam desistir de participar do experimento e que os dados obtidos seriam confidenciais. Todas essas informações constavam na Carta de informação ao Paciente e Termo de Consentimento Livre e Esclarecido (Anexos 3 e 4), a qual foi assinada em duas vias, sendo uma destinada ao voluntário e outra ao pesquisador.

\section{2 Delineamento experimental}

Esse estudo cruzado e cego foi realizado in situ, onde 10 voluntários utilizaram os dispositivos acrílicos intrabucais palatinos, os quais continham blocos de esmalte dental bovino. Para isto, incisivos bovinos foram seccionados $(4 \times 4 \times 2,5 \mathrm{~mm})$, polidos, selecionados (160 blocos) através da análise de microdureza superficial (SMH inicial). Metade dos blocos foram submetidos à produção de lesão de cárie artificial incipiente e submetidos novamente a microdureza. Em seguida os blocos desmineralizados (L) ou não (H) foram fixados nos dispositivos acrílicos. Estes dispositivos foram usados durante 4 fases de 14 dias, separados por intervalo de 1 semana. No decorrer do experimento, os voluntários seguiram o estudo cruzado e cego, cujo protocolo foi definido na seguinte seqüência: 3 vezes ao dia, logo após as principais refeições, a solução de sacarose a $20 \%$ era gotejada em uma fileira de blocos $(H)$, enquanto na outra fileira $(L)$ nada era realizado. Após 5 min de espera, o dispositivo retornava a boca e o voluntário bochechava, durante 1 min, $10 \mathrm{~mL}$ de solução de lactato de Ca 150 mM ou água deionizada (placebo). Em seguida, o voluntário removia o dispositivo e gotejava uma solução de dentifrício (1 g dentifrício:3 mL de água deionizada) com (1100) ou sem $\mathrm{F}$ 
(placebo) nos quatro blocos. Durante $1 \mathrm{~min}$, o voluntário escovava seus dentes com o mesmo dentifrício aplicado sobre os blocos. Ao finalizar o tempo, o dispositivo retornava a boca e por fim, a boca era enxaguada com $10 \mathrm{~mL}$ de água da torneira $(0,7$ ppm F).

Decorrido o tempo experimental, realizou-se a análise de $\mathrm{F}$ e $\mathrm{Ca}$ na placa bacteriana e nos blocos de esmalte foi analisada a microdureza superficial (SMH final), para o cálculo da porcentagem de variação de microdureza superficial (\% SMHC). Na seqüência, os blocos foram cortados ao meio, para a avaliação da microdureza em seção longitudinal, sendo transformado em porcentagem de volume mineral (\% vol min). Na outra metade do bloco realizou-se a biópsia básica para a remoção de $\mathrm{F}$ fracamente ligado, solúvel em álcali. Os dados foram analisados por ANOVA e Tukey $(p<0.05)$. 0 fluxograma do experimento está representado na figura 2. 


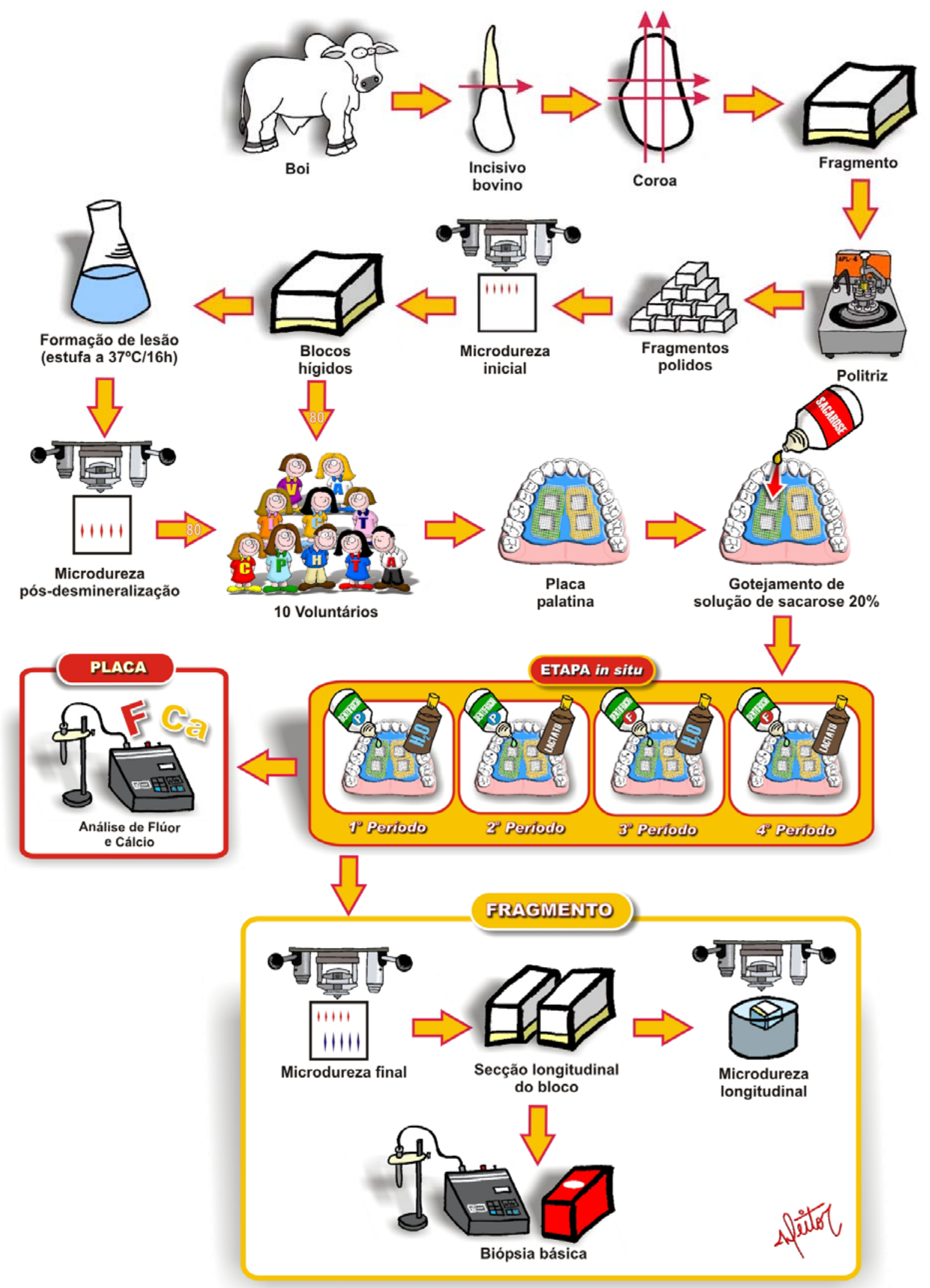

Figura 2 - Fluxograma do delineamento experimental 
58 Material e Métodos 


\subsection{Seleção dos voluntários}

Para este estudo, foram selecionados dez voluntários adultos jovens, com idades entre 18 e 30 anos, sendo todos do gênero feminino, residentes em Bauru - SP, cidade abastecida com água fluoretada (0,6 - 0,8 ppm). Todos os participantes eram alunos da Faculdade de Odontologia de Bauru (FOB-USP).

Os critérios considerados para inclusão no estudo foram: não deveriam estar tomando antibiótico e nem medicamentos que alterassem o fluxo salivar, ausência de cárie ativa ou doença periodontal, não tomar suplementos de flúor, e não ter recebido aplicação tópica de flúor profissional em altas concentrações nas duas últimas semanas.

\subsection{Preparo dos blocos de esmalte bovino}

4.4.1 Obtenção dos dentes e preparo dos blocos de esmalte bovino

Foram utilizados 500 dentes incisivos bovinos recentemente extraídos de gado da raça Nelore com idade média de 36 meses, abatidos para consumo no Frigorífigo Vangélio Mondelli Ltda, em Bauru, SP. Esses incisivos, livres de cárie, foram esterilizados com solução tamponada de formol 2\%, em pH 7,0 sob temperatura ambiente, por no mínimo 30 dias, e submetidos à análise visual com auxílio de uma lupa (JON), em ambiente iluminado com luz branca, para a averiguação de possíveis manchas e trincas, situação na qual foram excluídos da amostra.

A limpeza dos dentes selecionados foi realizada, removendo todo e qualquer resíduo de tecido gengival aderido à superfície com o auxílio de uma cureta periodontal (DUFLEX. Ind. Bras.) para preparar os dentes para o corte.

Primeiramente foram removidas as raízes, com o auxílio de um torno de polimento odontológico adaptado para corte (Fábrica Nacional de Motores Monofásicos Nevoni/ Série 16223, Tipo: TG1/3, São Paulo, SP) e um disco diamantado Diaflex-F (Wilcos do Brasil, Ind. e com. Ltda, Petrópolis, RJ), sendo feita uma secção na porção cervical dos dentes (Figura 3). 
60 Material e Métodos 


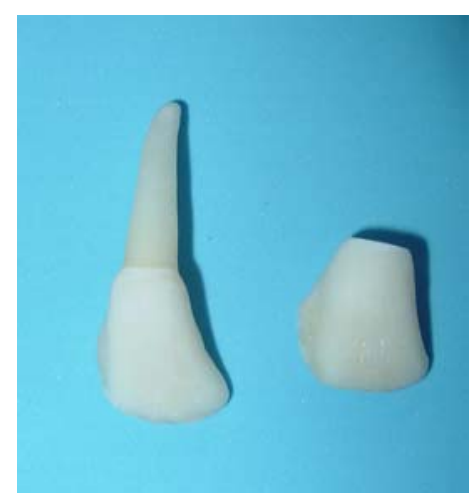

FIGURA 3 - Secção para separar coroa da raiz

Na seqüência, as coroas foram fixadas, uma a uma pela face palatina (Figura 4), com godiva de baixa fusão (Kerr) em uma placa de acrílico (40×40×5 $\mathrm{mm}^{3}$ ). A placa foi parafusada em um aparelho de corte de precisão ISOMET Low Speed Saw (Buehler Ltd, USA) e com dois discos diamantados dupla face - XL 12205, "High concentration", 102 x 0,3 x 12,7 mm³ (Extec Corp., Enfield, CT, USA/ Ref: 12205) e um espaçador de aço inoxidável (7cm de diâmetro, $4 \mathrm{~mm}$ de espessura e orifício central de 1,3cm) entre os discos (Figura 5), com velocidade de $300 \mathrm{rpm}$, refrigerado com água deionizada, foram obtidos os blocos de esmalte de $4 \times 4 \mathrm{~mm}$ da porção mais plana da coroa, através de uma secção dupla no sentido cérvico-incisal e outra no sentido mésio-distal (Figura $6)$.

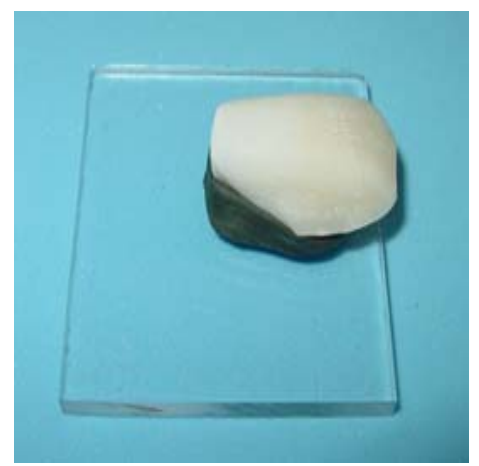

FIGURA 4 - Fixação da coroa para corte 
62 Material e Métodos 

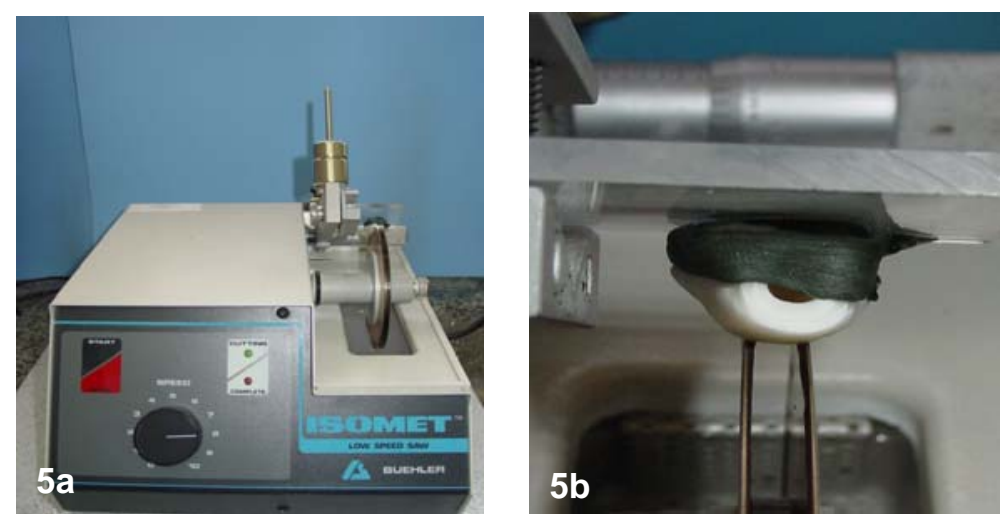

FIGURA 5 - a. Máquina de corte; b. Espécime posicionado para corte
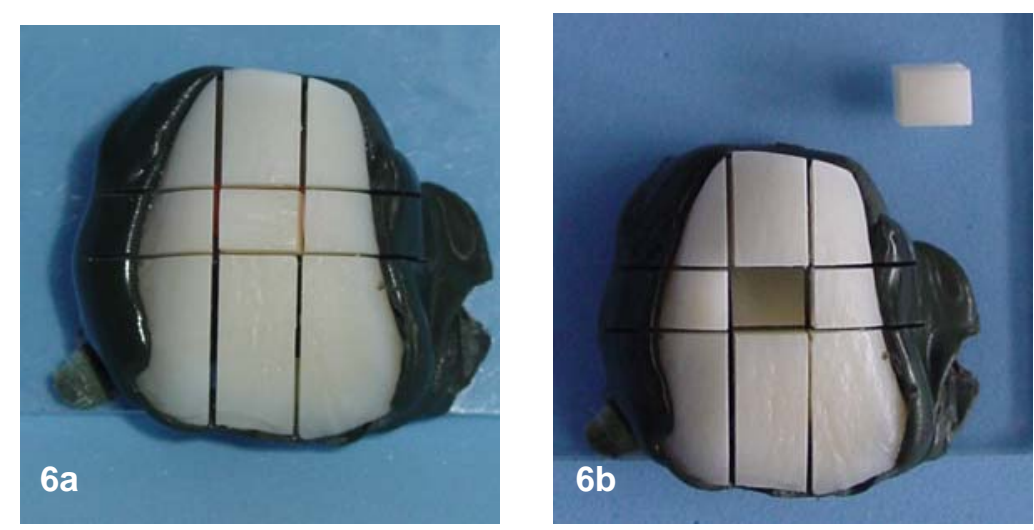

FIGURA 6 - a. Secções duplas no sentido mésio-distal e cérvicoincisal; b. Espécime obtido da região central

\subsubsection{Desgaste e polimento dos blocos de esmalte bovino}

Com uma lupa (JON), em ambiente iluminado com luz natural, realizouse uma segunda seleção dos blocos, excluíram-se aqueles que apresentaram trincas ou rachaduras no esmalte, assim como manchas hipoplásicas. Estes blocos foram submetidos a um polimento, para isso, foram fixados com cera em bastão para enceramento (Kota Ind. e Com. Ltda, São Paulo - SP, Brasil) com o auxílio de um instrumento de PKT (Duflex Ind. Bras.) e uma lamparina (JON, Ind. Bras.) no centro de um disco de acrílico (30 mm de diâmetro por 8 $\mathrm{mm}$ de espessura), com a face de esmalte voltada para o disco, com o intuito de realizar primeiramente a planificação da dentina. Seis conjuntos (disco/dente) foram adaptados em uma Politriz Metalográfica (APL 4, Arotec, Cotia - SP, Brasil) para realizar a planificação da dentina (Figura 7), permitindo o paralelismo entre as superfícies polidas e a base de acrílico no qual foram fixados os espécimes (Figura 8). Para tal, foi utilizada uma lixa de carbeto de 
64 Material e Métodos 
silício de granulação 320 (Silicon Carbide Waterproof Paper, Extec Abr. disc S/C, W/D, Extec ${ }^{\circledR}$ Corp.) acionada, sob refrigeração com água deionizada, durante 30 s a 3 min, em velocidade baixa e com dois pesos, até que os blocos apresentassem a superfície de dentina totalmente plana e uma espessura de 2 a 2,5 $\mathrm{mm}$ (espessura aferida com paquímetro). Os blocos com superfície de dentina muito irregular foram desgastados manualmente, nesta mesma lixa, antes de serem adaptados na politriz, para evitar que a lixa fosse rasgada durante a planificação.

Em seguida, os blocos foram removidos do disco de acrílico e os discos limpos com xilol (MERCK, Darmstadt, Germany), para que se retirasse todo o resíduo de cera aderido a eles. Posteriormente, os blocos foram novamente fixados com cera pegajosa no centro do disco de acrílico, com a face de esmalte voltada para cima. Este procedimento foi realizado com cuidado para que a cera não escorresse sob o bloco, o que alteraria o paralelismo entre as superfícies de esmalte e dentina, para que fosse realizado o polimento, objetivando a obtenção de uma superfície absolutamente plana e paralela à base, indispensável para a realização dos testes. Novamente o conjunto foi adaptado a politriz e o esmalte foi desgastado inicialmente com uma lixa de carbeto de silício de granulação 600, sob refrigeração com água deionizada, durante 2 minutos, com 2 pesos, em velocidade baixa. Em seguida, foi realizado o polimento do esmalte com lixa de carbeto de silício de granulação 1200 (Extec Corp.), sob refrigeração, durante 3 minutos, com 2 pesos, em velocidade alta. Para finalizar o polimento, utilizou-se um feltro (Extec Corp.) umedecido com uma suspensão de diamante de $1 \mu \mathrm{m}$ (Buehler), durante 3 minutos, com 2 pesos, em velocidade alta.

Para impedir que os grãos das primeiras lixas interferissem na qualidade do polimento das seguintes, entre cada etapa de polimento, o conjunto dente/disco (aproximadamente 16 blocos por vez) foi levado a um aparelho de ultra-som T7 Thornton, com freqüência de $40 \mathrm{KHz}$, com $1700 \mathrm{~mL}$ de água deionizada, por 2 minutos (Figura 9). Ao final do polimento os blocos foram levados novamente ao ultra-som por 10 minutos com o objetivo de se retirar totalmente o excesso da solução diamantada. Para o prosseguimento das etapas, os blocos deveriam apresentar a superfície de esmalte com aspecto vítreo (Figura 10). 
66 Material e Métodos 
Para checar a qualidade do polimento, os blocos foram levados a um microdurômetro (HMV - 2000/Shimadzu Corporation, Japan/ Ref.: 163013500010), acoplado a um software para análise de imagem (Cams - Win - New Age Industries/USA), para verificação da qualidade do polimento. Caso a superfície de esmalte ainda apresentasse muitas irregularidades, riscos muito marcantes ou em grande quantidade, o polimento seria repetido utilizando-se as lixas 600 e 1200, por mais 30 segundos, intercaladas pelos banhos intermediários, repetindo-se também o banho final.

Após este procedimento, os blocos passaram a ser armazenados em recipientes plásticos com tampa, cobertos com gaze umedecida em água deionizada, à $4^{\circ} \mathrm{C}$, a fim de se evitar a formação de trincas na superfície do esmalte.

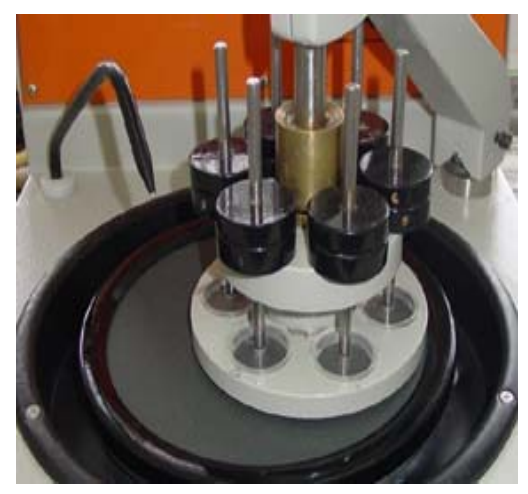

FIGURA 7 - Politriz metalográfica

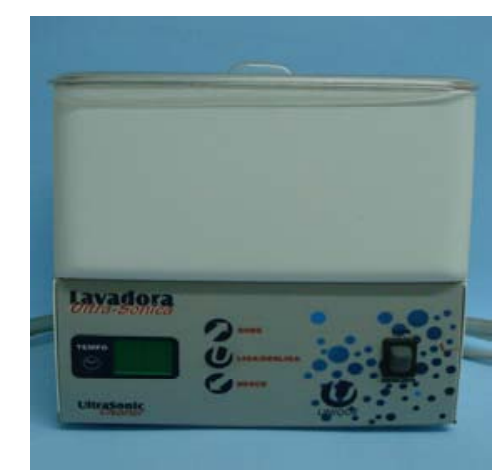

FIGURA 9 - Aparelho de ultrasom

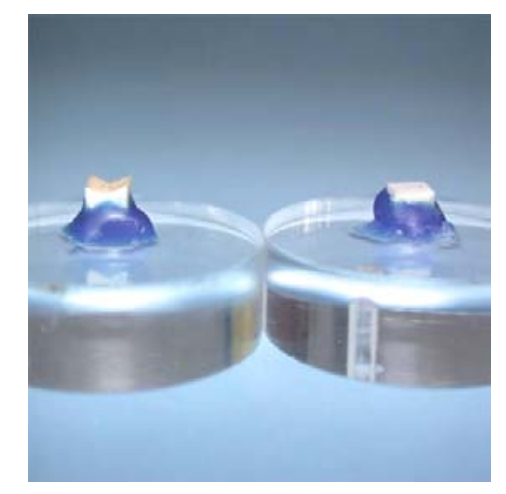

FIGURA 8 - Blocos antes e após a planificação da dentina

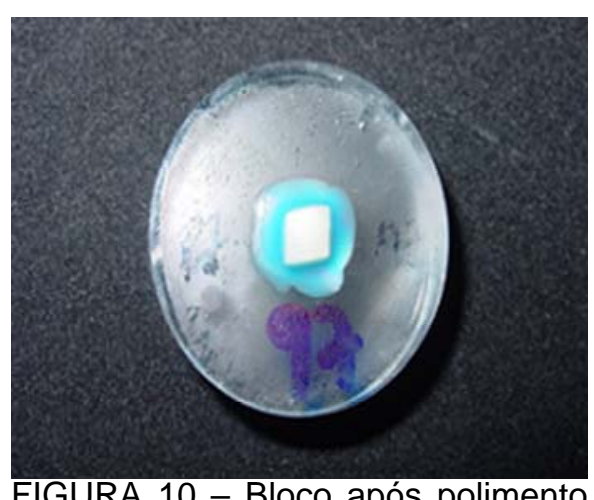

do esmalte 
68 Material e Métodos 


\subsection{Avaliação da microdureza superficial inicial}

Para a análise da microdureza superficial do esmalte, foi utilizado o microdurômetro SHIMADZU MICRO HARDNESS TESTER HMV-2.000 (Figura 11) (Shimadzu Corporation - Kyoto-Japan), com penetrador diamantado piramidal tipo Knoop (KHN), carga estática de $25 \mathrm{~g}$ com tempo de 10 segundos (Figura 12), acoplado ao Software para análise de imagem CAMS-WIN (NewAge Industries, USA). Foram feitas 5 indentações equidistantes $100 \mu \mathrm{m}$ entre si no centro dos blocos de esmalte antes dos tratamentos (SMH inicial). Para medir as indentações, duas marcas pontilhadas que apareciam na tela do computador se sobrepunham aos vértices agudos do losango correspondente à indentação, determinando o comprimento da maior diagonal (Figura 13) e, conseqüentemente, os resultados da dureza KNOOP através do cálculo automático feito pelo software da seguinte equação:

$$
\begin{array}{ll}
\text { KNH = } \frac{\text { C.c }}{\mathbf{d}^{2}} & \text { KNH = valor de dureza KNOOP } \\
& \text { C (constante) }=14,230 \\
& c=25 \mathrm{~g} \\
& \mathrm{~d}=\text { comprimento da maior diagonal da indentação }
\end{array}
$$

Dos 500 blocos inicialmente obtidos, um total de 250 blocos foi selecionado a partir da média geral da SMH $350 \pm 15 \mathrm{KHN}$, com variação permitida dentro de $10 \%$ desta média. Dentro desses 250 blocos, 90 foram utilizados para um estudo piloto a cerca de produção de lesão de cárie incipiente, enquanto que os outros 160 foram utilizados na fase in situ.

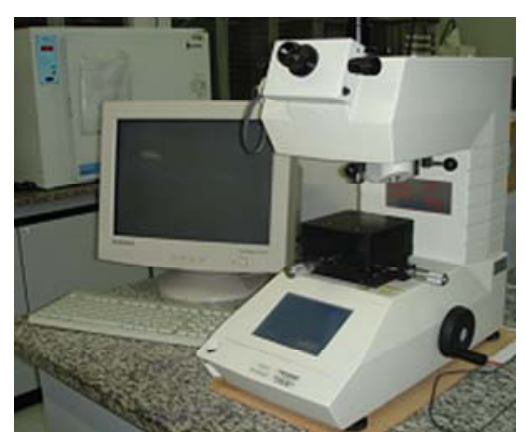

FIGURA 11 - Microdurômetro acoplado ao computador

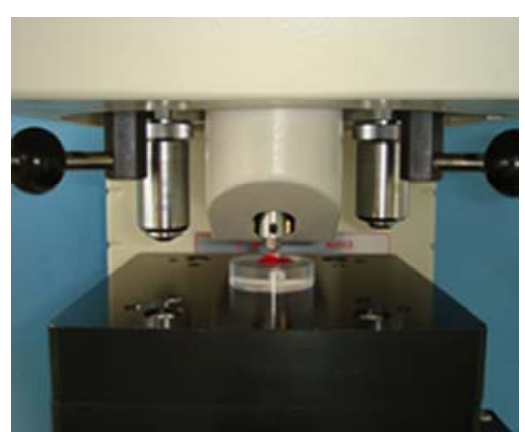

FIGURA 12 - Ponta apalpadora tipo KNOOP 
70 Material e Métodos 


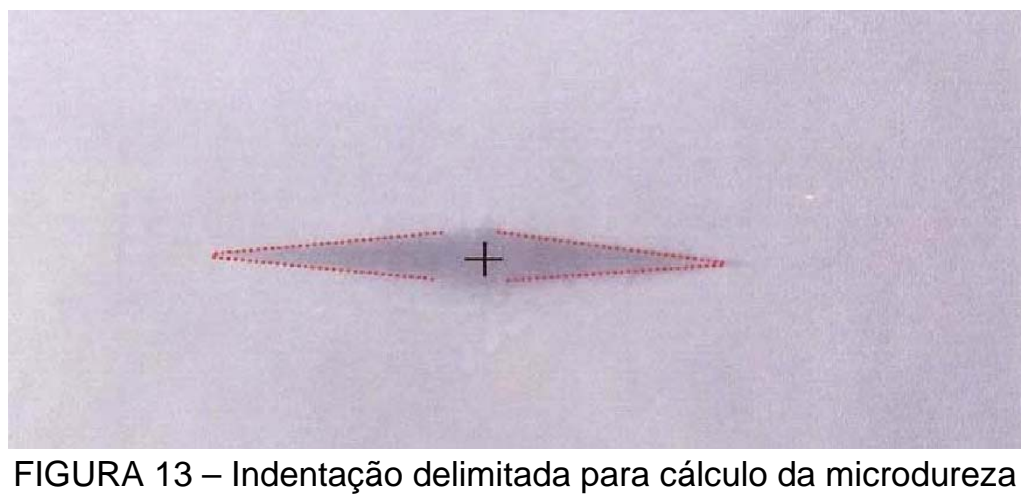

\subsection{Indução da lesão de cárie in vitro}

Para a produção de lesão artificial de cárie nos blocos, estes foram imersos em solução contendo $1,3 \mathrm{mmol} / \mathrm{L} \mathrm{Ca}, 0,78 \mathrm{mmol} / \mathrm{L} \mathrm{P}$ em tampão acetato 0,05 mol/L, em pH 5,0 e 0,0315 ppm F (QUEIROZ ${ }^{75}, 2004$ ). Um dia antes do preparo, os reagentes foram armazenados em dessecador, para a remoção da umidade que poderia influenciar na pesagem, especialmente o sal de cálcio que é altamente higroscópico. Os reagentes utilizados para o preparo de $1 \mathrm{~L}$ de solução estão descritos na tabela 1.

TABELA1 - Reagentes utilizados para o preparo de $1 \mathrm{~L}$ de solução para formação de cárie artificial

\begin{tabular}{ccc}
\hline Reagentes & Fabricante & Solução (pH 5) \\
\hline $\mathrm{Ca}\left(\mathrm{NO}_{3}\right)_{2 .} 4 \mathrm{H}_{2} \mathrm{O}$ & Merck & $1,3 \mathrm{mM}(0,30699 \mathrm{~g})$ \\
$\mathrm{Na}_{2} \mathrm{HPO}_{4 .} 2 \mathrm{H}_{2} \mathrm{O}$ & Merck & $0,78 \mathrm{mM}(0,1076322 \mathrm{~g})$ \\
Ácido acético glacial & Merck & $50 \mathrm{mM}(2,87 \mathrm{~mL})$ \\
$\mathrm{NaF}(100$ ppm) & Orion & $0,0315 p p m(315 \mu \mathrm{L})$ \\
\hline
\end{tabular}

Para o preparo de $1 \mathrm{~L}$ de solução, $800 \mathrm{~mL}$ de água deionizada foram colocados em um Becker de 1L. A cada 5 minutos, um reagente foi adicionado, sob agitação, na seguinte seqüência: sal de cálcio, ácido acético glacial, sal de fosfato e flúor. Para o ajuste do $\mathrm{pH}(5,0), \mathrm{NaOH} 1 \mathrm{M}$ foi pipetado na solução. Para este estudo foi preparado um volume de 5,5 $\mathrm{L}$ de solução.

Os espécimes foram vedados com esmalte cosmético para unhas (Colorama Maybelline - ultra duração, Cosbra Cosméticos Ltda, São Paulo SP, Brasil) (Figura 14). Na seqüência, os blocos foram envoltos também por cera pegajosa, a fim de se garantir que apenas a superfície do esmalte 
72 Material e Métodos 
permanecesse exposta e presos a um fio ortodôntico (Figura 15), permanecendo assim, imersos na metade do pote plástico, por 16 horas em 32 $\mathrm{mL}$ da solução e mantidos em estufa a $37^{\circ} \mathrm{C}$ (VIEIRA et al. ${ }^{103}$, 2005).

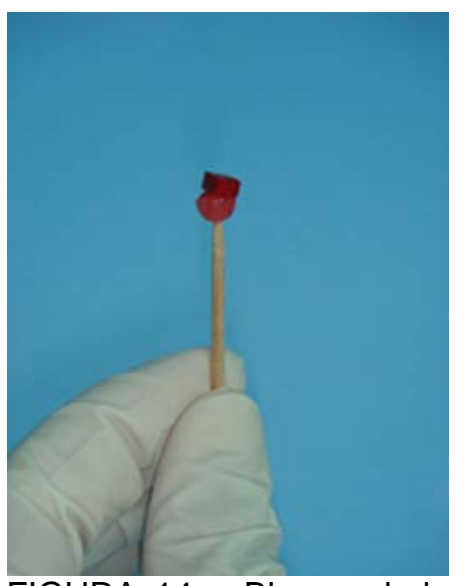

FIGURA 14 - Bloco selado com esmalte de unha

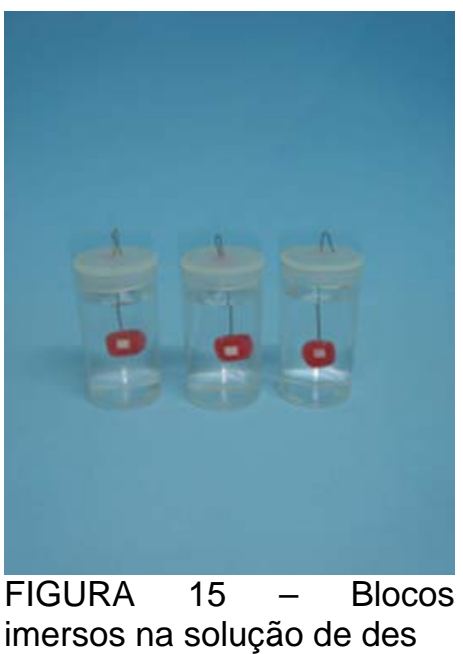

imersos na solução de des

\subsection{Avaliação da microdureza superficial após a desmineralização}

A microdureza superficial do esmalte foi avaliada novamente, utilizandose o mesmo equipamento e a mesma metodologia descrita anteriormente. A porcentagem de variação foi calculada com a seguinte fórmula: \%SMH= $\left\{\left[(\mathrm{SMH}-\mathrm{SMH} \text { lesão)/SMH }]^{\star} 100\right\}\right.$ (VIEIRA et al. $\left.{ }^{103}, 2005\right)$. A média da \%SMHC foi de $72,8 \pm 8 \%$.

\subsection{Amostra}

Para o estudo 160 blocos foram necessários, sendo metade hígidos $(n=80)$ e a outra metade com lesão artificial de cárie $(n=80)$, os quais foram aleatoriamente alocados para as 4 fases experimentais (Figura 16) de acordo com a média de SMH e \%SMHC, respectivamente (Anexo 5). Em seguida, os blocos de cada grupo experimental foram aleatoriamente alocados para os 10 voluntários. 
74 Material e Métodos 
Fase 1 - Placebo.

Fase 2 - Somente solução de cálcio

Fase 3 - Somente dentifrício com $\mathrm{F}$

Fase 4 - Solução de cálcio + Dentifrício com F.

Figura 16 - Descrição das 4 fases experimentais.

\subsection{Protocolo do estudo in situ}

Esta etapa contou com a participação de 10 voluntários em um protocolo cruzado e cego, realizado em 4 fases de 14 dias cada. Os voluntários utilizaram um dispositivo palatino de acrílico contendo 4 blocos de esmalte bovino (4X4X2,5 mm), sendo 2 hígidos $(H)$ e 2 com lesão artificial de cárie (L). A solução de sacarose foi aplicada nos blocos de esmalte hígido $(H)$ enquanto nos blocos com lesão artificial de cárie nada foi aplicado, levando ao surgimento de duas situações: desmineralização do esmalte hígido e remineralização do esmalte com lesão artificial de cárie.

Para isso, cada voluntário recebeu uma pasta com uma lista de instruções e um formulário para relatório (Anexo 4); uma maleta plástica contendo (Figura 17): um estojo plástico para guardar o dispositivo intrabucal; uma bisnaga de dentifrício fluoretado ou placebo; dois copos dosadores (10 $\mathrm{mL}$ ) para realização do bochecho com lactato ou placebo e para o enxágüe após a escovação; um frasco de solução de sacarose a 20\% (o qual era substituído a cada 2 dias); um frasco contendo solução de dentifrício fluoretado ou placebo (o qual era substituído 1 vez por semana); um frasco contendo solução de bochecho de lactato de cálcio ou placebo (que era reposto sempre que necessário); uma escova de dentes para ser utilizada durante o experimento, Bitufo ${ }^{\circledR}$, número 28, extra-macia (Bitufo, Jundiaí, SP, São Paulo, Brasil); além de porções de gaze (Cremer S. A. Ind. Brás, Blumenau, SC). A gaze e o dentifrício eram repostos quando necessário. 
76 Material e Métodos 


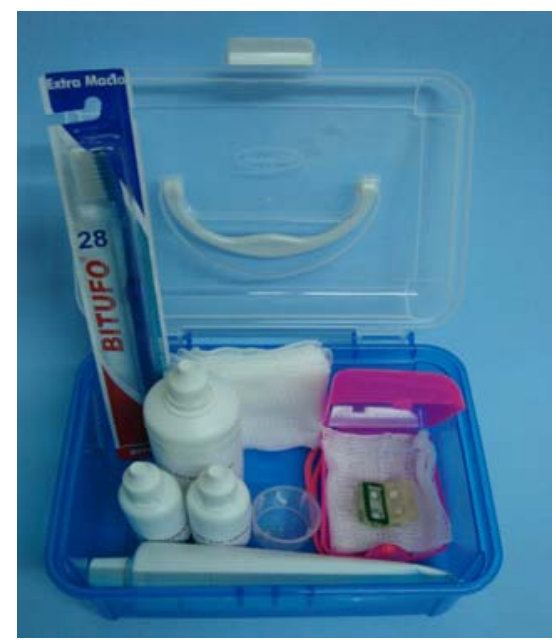

FIGURA 17 - Kit entregue a cada voluntário

O aparelho foi instalado um dia antes do início da fase experimental para formação da película adquirida (Figura 18). Os voluntários foram instruídos a usar os dispositivos durante todo o dia, exceto às refeições, quando os dispositivos permaneciam no interior do estojo plástico envoltos em gaze umedecida em água de abastecimento (0,6 a 0,8 ppm F), e a manter seus hábitos dietéticos normais, além de não usarem antissépticos bucais. Para um melhor controle desta etapa, os voluntários preencheram um relatório diário a fim de se controlar os alimentos ingeridos e as possíveis alterações ocorridas durante o experimento (Anexo 6).

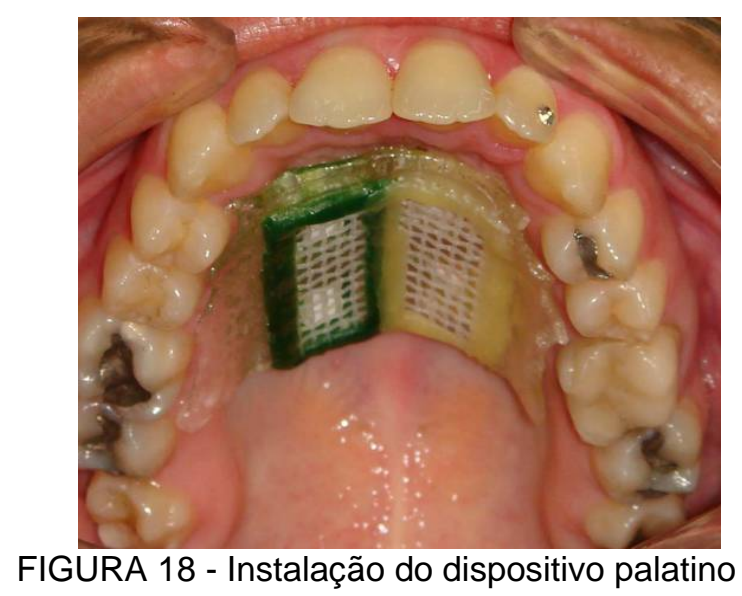

As quatro fases foram compostas por diferentes tipos de tratamento com o objetivo de testar se o bochecho com cálcio associado ao uso de dentifrício fluoretado poderia diminuir a desmineralização (blocos hígidos) e interferir na 
78 Material e Métodos 
remineralização (blocos com cárie artificial): bochecho placebo (água deionizada) e dentifrício placebo; bochecho com lactato de cálcio 150mM e dentifrício placebo (sem flúor); uso de bochecho placebo e dentifrício fluoretado (1000 ppm F, NaF, Crest) e bochecho com lactato de cálcio 150 mM e dentifrício fluoretado (1000 ppm F, NaF, Crest),. Esta solução de Ca foi escolhida baseada no trabalho de VOGEL et al. ${ }^{106}, 2004$.

O protocolo in situ foi realizado 3 vezes por dia, durante 14 dias, após as principais refeições, nas quais os dispositivos palatinos foram retirados da boca. Os voluntários aplicaram solução de sacarose a $20 \%$ sobre os blocos hígidos (3 gotas/ bloco) da fileira com cera de cor verde (CURY et al. ${ }^{27}, 2001$ ) (Figura 19). Após cinco minutos, o aparelho retornou à boca e os voluntários bochecharam $10 \mathrm{~mL}$ da solução de cálcio ou água deionizada, durante 1 minuto (Figura 20). Na seqüência, o aparelho foi retirado da boca e a solução de dentifrício (1 dentifrício: 3 água deionizada) foi gotejada nos 4 blocos (3 gotas/ bloco) (Figura 21). Enquanto aguardavam 1 min, os voluntários escovaram seus dentes com o mesmo dentifrício aplicado nos blocos. Ao finalizar o tempo, o aparelho retornou a boca e a cavidade foi enxaguada com $10 \mathrm{~mL}$ de água da torneira. Houve um período de descanso de pelo menos 7 dias entre as etapas para se excluir a possibilidade de interferências. Uma semana antes de iniciar o experimento e nos períodos entre as etapas, os voluntários utilizaram dentifrício placebo.

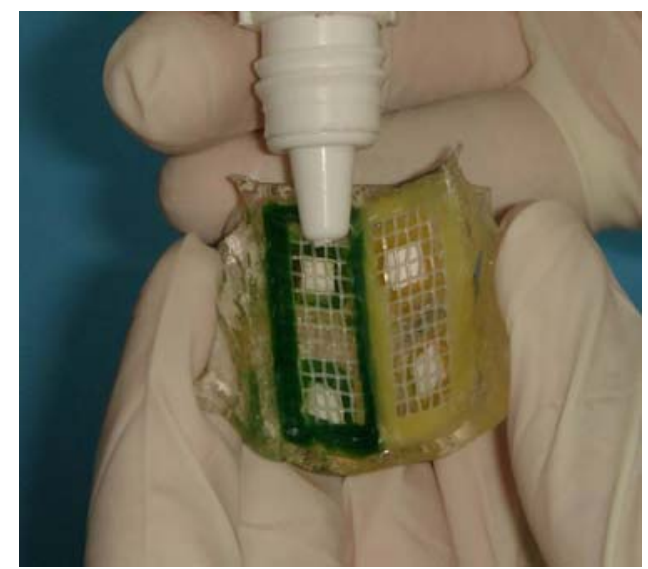

FIGURA 19 - Gotejamento da solução de sacarose a $20 \%$ sobre os blocos de esmalte 
80 Material e Métodos 

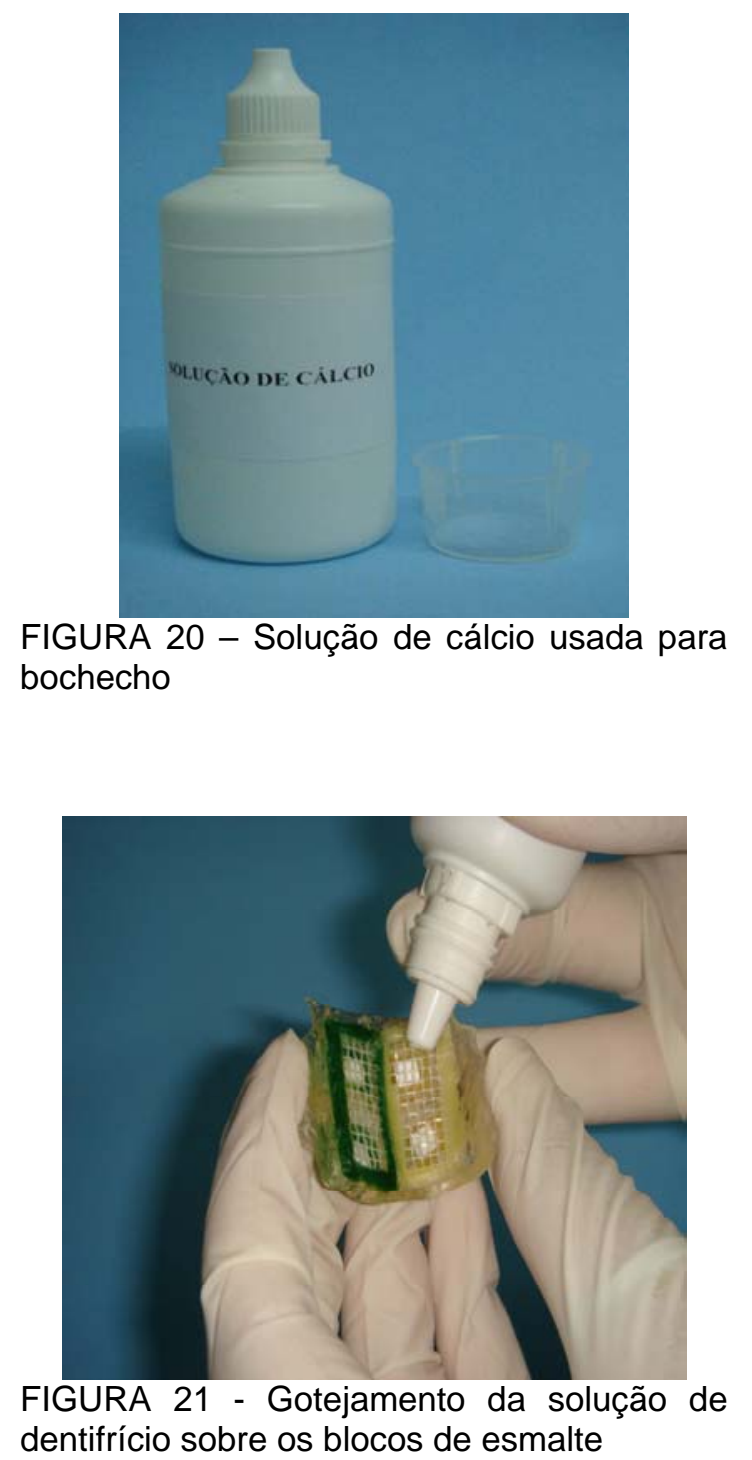

\subsection{Análise de cálcio e flúor da placa bacteriana}

$\mathrm{Na}$ manhã do dia previsto para a coleta da placa, os voluntários permaneceram em jejum ao entregarem os dispositivos acrílicos. No mesmo momento, a tela que recobria os blocos do dispositivo de acrílico palatino foi removida e a placa coletada com auxílio de espátula plástica (Jon - Com. de produtos odontológicos Ltda., São Paulo - SP, Brasil) (Figura 22). 
82 Material e Métodos 


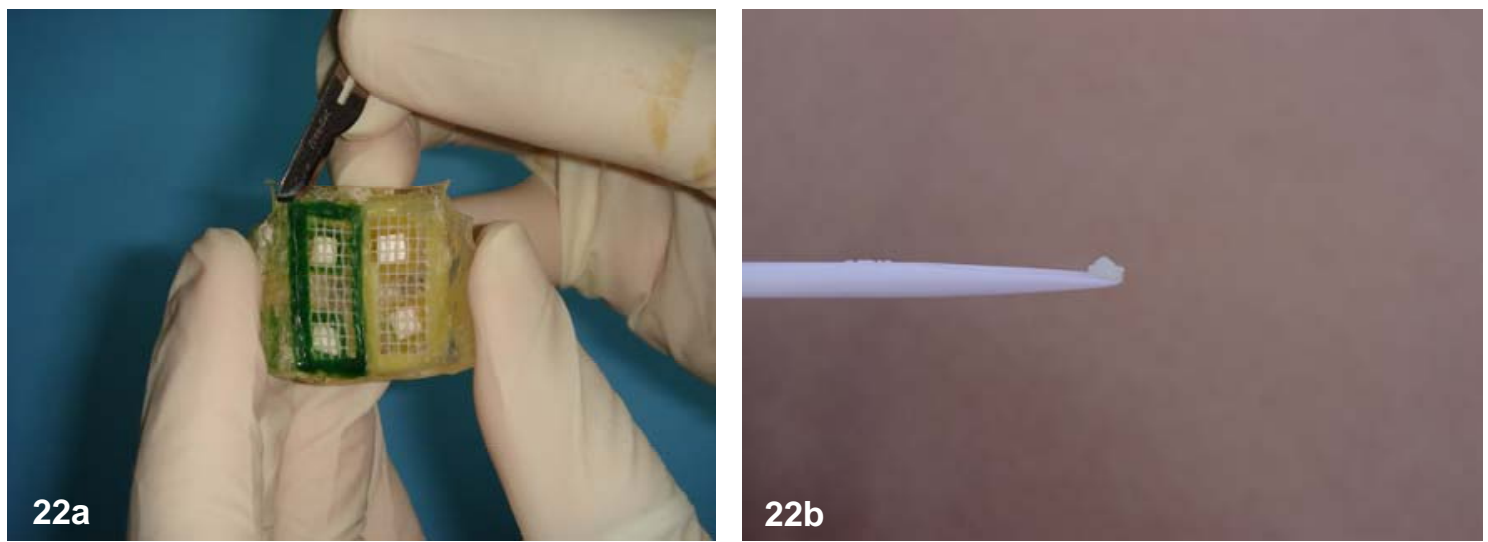

FIGURA 22 - a. Retirada da tela com bisturi; b. Placa bacteriana coletada com espátula plástica

A placa foi pesada em balança de precisão Mettler Toledo (modelo AT 261, Delta Range, Suíça), em tubos para microcentrífuga previamente pesados, com aproximadamente $10 \mathrm{mg}$ de placa por tubo. A seguir, adicionouse $\mathrm{HCl}$ 0,5 M, na proporção de 0,5 mL/10 mg placa (peso úmido). O conjunto foi homogeneizado em aparelho agitador de tubos (modelo 251, Fanem, São Paulo, Brasil) e, em seguida, os tubos foram mantidos sob agitação constante (mesa agitadora orbital plana - Nova Técnica, modelo NT 145, Piracicaba, São Paulo Brasil), durante $3 \mathrm{~h}$ à temperatura ambiente (Figura 23). Após este procedimento, um mesmo volume de Tisab II (20 g NaOH/L), tampão de ajuste de força iônica, foi adicionado ao tubo, centrifugado por 1 min a $11000 \mathrm{~g}$ (centrífuga modelo A14, Jovan S. A., Herblain, França) e as concentrações de F e Ca ácido-solúveis foram analisadas (PEARCE ${ }^{69}, 1984$; BENELLI, et al. ${ }^{13}$, 1993). 
84 Material e Métodos 

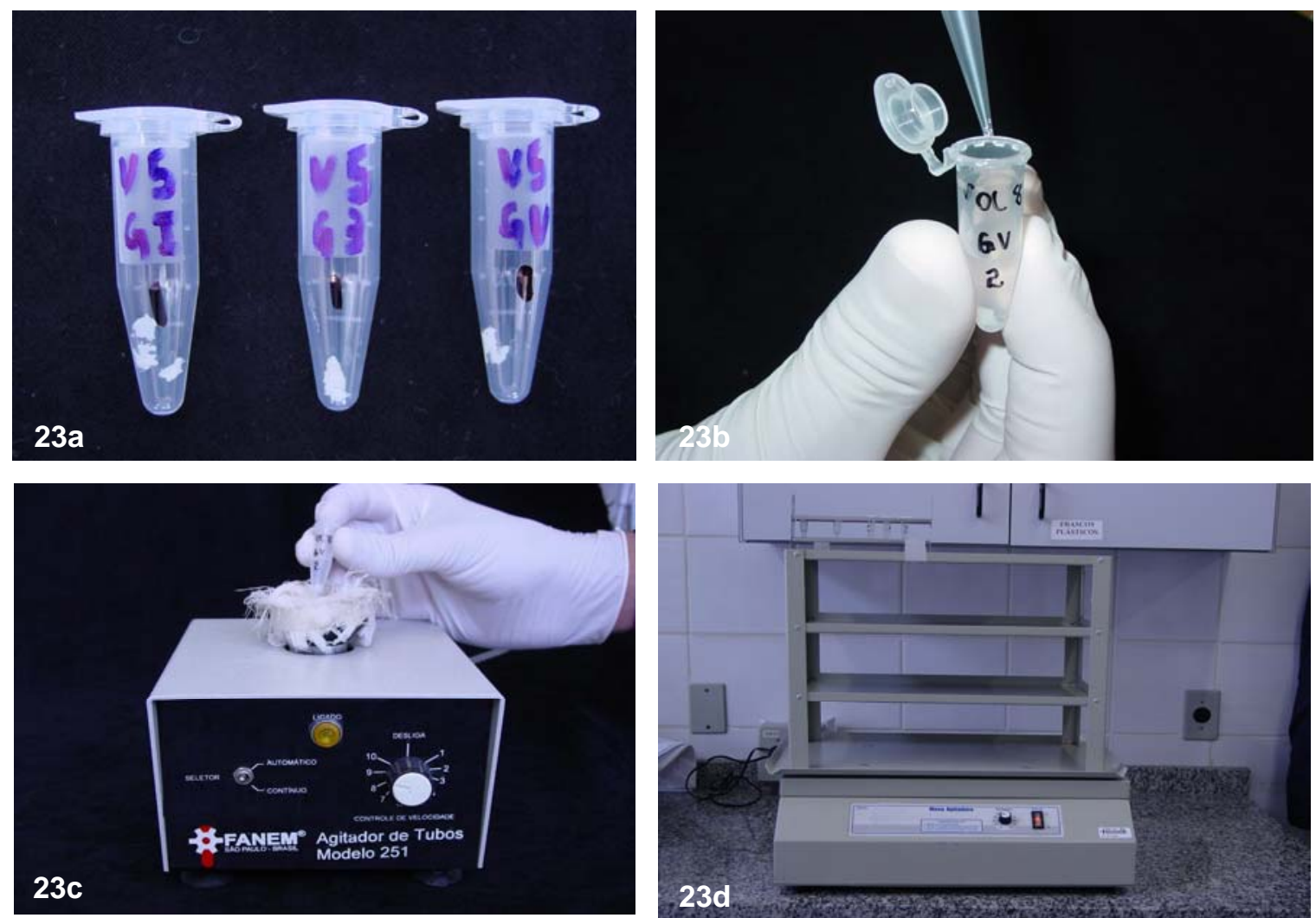

FIGURA 23 - a. Placa bacteriana nos tubos de microcentrífuga; b. Adição de $\mathrm{HCl} \mathrm{0,5} \mathrm{M;} \mathrm{c.}$ Agitação em agitor de tubos; d. Agitação em mesa agitora por $3 \mathrm{~h}$

No extrato ácido da placa, o flúor foi analisado com o eletrodo íon específico combinado (modelo 96-09, Orion, MA, EUA) e um analisador de íons Orion (modelo EA 940, Orion), como demonstrado por HALLSWORTH et al. ${ }^{38}$, em 1976 (Figura 24). Esta técnica foi utilizada por permitir análise de pequenos volumes de amostras (3-5 $\mu \mathrm{L})$. Nesta técnica, utiliza-se o eletrodo íon específico combinado na posição normal e a gota da solução a ser analisada é confinada entre a superfície do eletrodo e uma junção líquida, feita em resina acrílica, montada imediatamente abaixo do eletrodo. A junção é conectada a um eletrodo de referência por uma ponte salina, consistindo num tubo de polietileno preenchido com uma solução saturada de $\mathrm{KCl}$ (3 $\mathrm{M})$. A amostra é colocada sobre a superfície da interface de acrílico, conectada ao eletrodo de referência (calomelano) através de um tubo de látex. Este tubo deve estar completamente preenchido por uma solução de KCl (3M - Fisher SP 138-500), sem bolhas. No momento do preenchimento, deve haver extravasamento da solução para o espaço entre a superfície interna e a externa, estando ambas justapostas. Após a colocação da amostra sobre esta superfície, coloca-se o 
86 Material e Métodos 
eletrodo de flúor em contato com a mesma e aguarda-se 60 segundos. Este procedimento deve ser realizado 3 vezes sem, no entanto, anotar-se o valor. Após a $4^{\mathrm{a}}$ leitura, o valor $(\mathrm{mV})$ é anotado. Este procedimento é necessário uma vez que o tempo de 60 segundos é insuficiente para que o eletrodo atinja a estabilidade necessária. Por outro lado, tempos maiores que 60 segundos podem permitir uma evaporação excessiva da amostra (volume muito pequeno) ou a contaminação da mesma pela solução de $\mathrm{KCl}$ presente no dispositivo de interface.

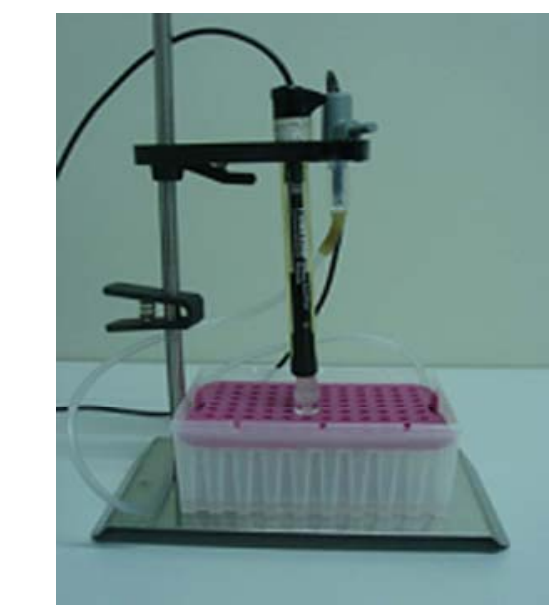

FIGURA 24 - Eletrodo íon específico combinado e analisador de íons Orion

Para a análise, foi feita uma curva de calibração com padrões de concentração de flúor contendo 0,$1 ; 0,2 ; 0,4 ; 0,8 ; 1,6 ; 3,2 ; 6,4 ; 12,8 ; 25,6 ; 51,2$ e 256 mgF/L, obtidos por diluição seriada de um estoque de 100 ppm F (Orion), conforme descrito no anexo 7, com exceção do padrão de $256 \mathrm{mgF} / \mathrm{L}$, que foi obtido a partir do sal de $\mathrm{NaF}$ (Merck). Foram utilizados para a realização da curva, 1,25 $\mu \mathrm{L}$ dos padrões mencionados, adicionados de 1,25 $\mu \mathrm{L}$ de $\mathrm{HCl}$ 1,0 $\mathrm{M}$, e 2,5 $\mu \mathrm{L}$ de TISAB II. Já para as amostras, foi utilizado um volume de 2,5 $\mu \mathrm{L}$, acrescidos de 2,5 $\mu \mathrm{L}$ de TISAB II. As leituras foram feitas em $\mathrm{mV}$, sendo transformadas em ngF/mg placa, através de planilha gerada no software Microsoft Excel.

A análise do cálcio presente no restante da amostra foi realizada através da espectrofotometria de absorção atômica (método de chama), usando o espectrômetro de absorção atômica AAS vario 6 (Analytikjena AG, Alemanha), utilizando-se lantânio para suprimir a interferência do fosfato. O aparelho foi 
88 Material e Métodos 
calibrado com soluções padrão de Ca contendo 80, 200, 400, 600 e 800 Mg Ca. As leituras foram obtidas em $\mathrm{mg} / \mathrm{L}$ e convertidas em $\mu \mathrm{g} / \mathrm{mg}$ de placa, através de planilha gerada no software Microsoft Excel.

\subsection{Limpeza e secção dos espécimens}

Os espécimes foram removidos do dispositivo palatino, limpos e desinfetados com uma solução de clorexidina a 0,12\%. Em seguida foram fixados em uma placa de acrílico e seccionados longitudinalmente através do material em máquina de corte de precisão Isomet Low Speed Saw (Buehler), com velocidade de 300 rpm e refrigeração com água deionizada. Foi utilizado um disco diamantado dupla face (Extec ${ }^{\circledR}$ Corp.) para realizar um corte na região central do espécime, porém deslocado para um dos lados. A parte mais grossa foi utilizada para avaliação da concentração de F no esmalte (biópsia básica de esmalte) que necessitava de uma área maior, enquanto a parte mais fina foi utilizada para avaliação da microdureza longitudinal.

\subsection{Análise da microdureza superficial final e interna}

As alterações do esmalte foram avaliadas pelo teste de microdureza superficial final (SMH1), a partir do qual calculou-se a porcentagem de alteração de dureza com as seguintes fórmulas: \%SMHC Hígido $=100\left(\mathrm{SMH}_{1}-\right.$ $\mathrm{SMH}) / \mathrm{SMH}$ e \%SMHC Lesão de cárie = (SMH2 $-\mathrm{SMH}$ lesão $)(\mathrm{SMH}-\mathrm{SMH}$ lesão)*100.

Para fazer a microdureza interna, os blocos foram secionados longitudinalmente (1/3 da superfície foi utilizada para a microdureza e 2/3 para a biopsia do esmalte). A parte correspondente a microdureza foi incluída em resina acrílica na embutidora (figura 25) e polida de forma semelhante à descrita no $1^{\circ}$ tópico do Material e Métodos. Três indentações foram feitas a 10 , $30,50,70,90,110,220$ e $330 \mu \mathrm{m}$ do esmalte superficial, completando um total de 24 indentações/ bloco. Foi calculada a média dos 8 pontos de medida. A área sob a curva $(\mathrm{KHN} \times \mu \mathrm{m})$ foi determinada através do cálculo integral utilizando a regra trapezoidal simples (FEATHERSTONE et al. ${ }^{35}$, 1983), de acordo com a seguinte fórmula: 
90 Material e Métodos 


$$
\begin{aligned}
(\mathrm{KHN} \times \mu \mathrm{m})= & 10 x\left(\mathrm{KHN}_{10}+2 x \mathrm{KHN}_{30}+2 x \mathrm{KHN}_{50}+2 x \mathrm{KHN}_{70}+2 x \mathrm{KHN}_{90}+\right. \\
& \left.1 \times \mathrm{KHN}_{110}\right)+55 \times\left(\mathrm{KHN}_{110}+2 x \mathrm{KHN}_{220}+\mathrm{KHN}_{330}\right)
\end{aligned}
$$
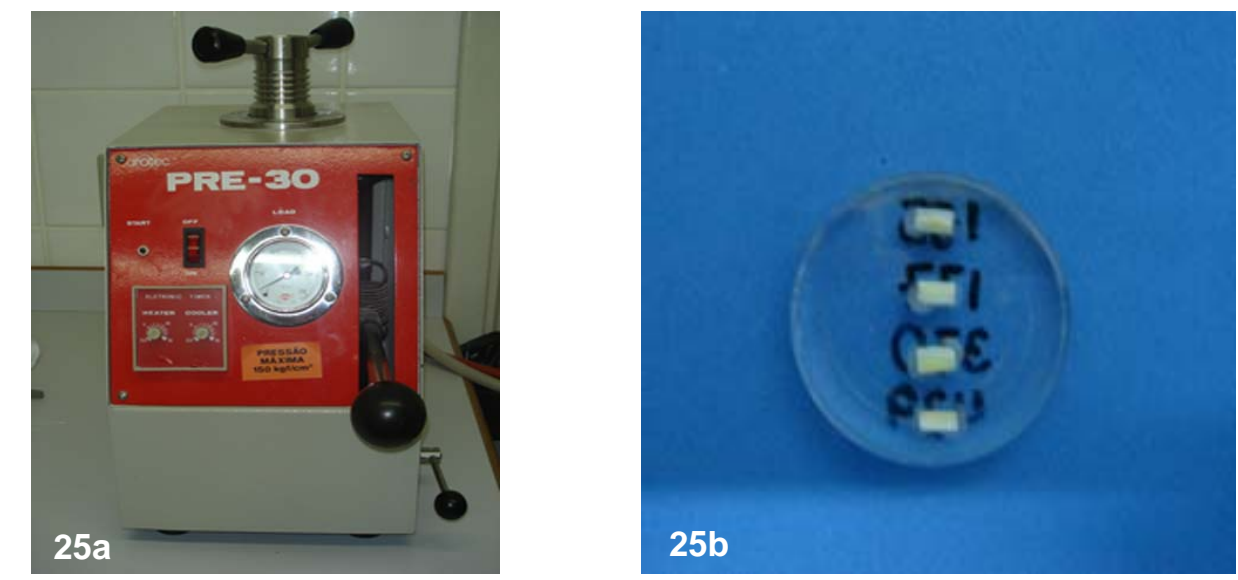

FIGURA 25 - a. Embutidora de espécimes; b. Espécimes embutidos em resina acrílica

\subsection{Análise da concentração do flúor fracamente ligado}

Nos 2/3 restantes dos blocos, foi avaliada a quantidade de $\mathrm{F}$ fracamente ligado $\left(\mathrm{CaF}_{2}\right)$, solúvel em álcali (CASLAVSKA et al. $\left.{ }^{21}, 1975\right)$. Os blocos de esmalte foram imersos e limpos em uma solução de acetona diluída em água deionizada (1:1), durante \pm 30 segundos, e secos em gaze esterelizada. Os espécimes foram manuseados somente com as pinças para que não houvesse a incorporação de partículas de gordura oriundas da mão. A seguir, uma fita adesiva foi perfurada por um perfurador de dique de borracha. Esta área circular da fita foi colada sobre a superfície do esmalte controle (não submetido a tratamento, $2,5 \mathrm{~mm}^{2}$ ) e no esmalte dos blocos submetidos aos diferentes tratamentos $\left(2 \mathrm{~mm}^{2}\right)$ por meio de uma pinça. Todas as superfícies do esmalte, com exceção desta área com a fita, foram seladas com cera utilidade (Figura 26). 
92 Material e Métodos 


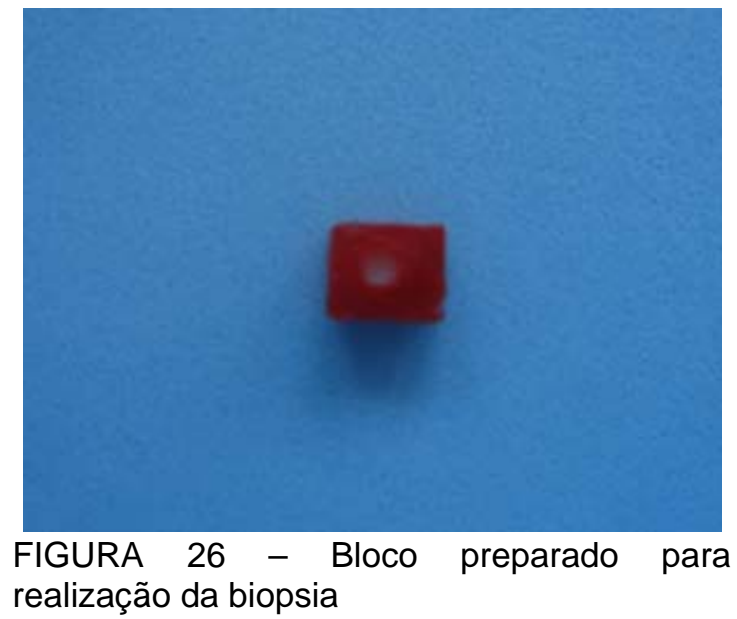

Para a realização da biopsia, inicialmente foram preparadas soluções de $\mathrm{KOH} 1 \mathrm{M}$ e $2 \mathrm{M}$. Para tal, foi necessário conhecer o peso molecular e o grau de pureza $\left(P M=56,11\right.$ - 85\% de pureza, marca Carlo Erba $\left.{ }^{\circledR}\right)$ do $\mathrm{KOH}$, para a realização do cálculo da massa a ser diluída em água, considerando a massa em relação à pureza através de uma regra de três (Figura 27).

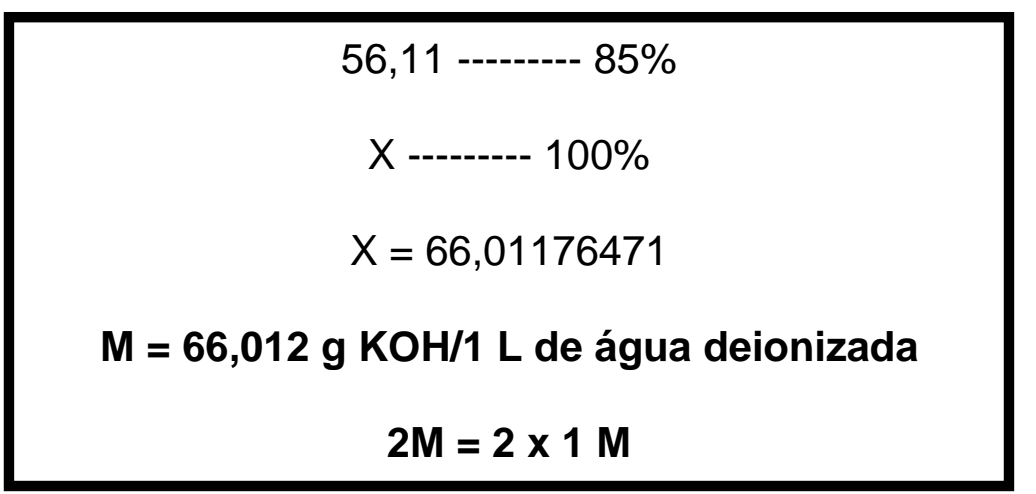

Figura 27 - Regra de três para o cálculo da massa a ser diluída em água deionizada para se obter a Molaridade

O TISAB II (HCl $1 \mathrm{M}$ ) também foi preparado, misturando-se $100 \mathrm{~mL}$ de TISAB a 8,5 mL de $\mathrm{HCl}$ concentrado (marca comercial Synth ${ }^{\circledR}$ ). Para testar 0 TISAB II (HCl), misturou-se $2 \mathrm{~mL}$ de $\mathrm{KOH}$ a $2 \mathrm{~mL}$ do TISAB II (HCl) e mediu-se o pH da mistura que deveria estar próximo a 5,2, possibilitando a leitura pelo eletrodo.

Após o preparo das soluções, os blocos foram imersos em 0,3 $\mathrm{mL}$ de $\mathrm{KOH} 1 \mathrm{M}$ por 24 horas, sob agitação e então neutralizados com 0,3 mL de TISAB II (contendo 8,5 ml HCl/ $100 \mathrm{ml}$ TISAB II) (Figura 28). O F presente na 
94 Material e Métodos 
solução neutralizada foi analisado com o eletrodo íon-específico (modelo 9609, Orion), depois de devida calibração de acordo com o Anexo 7. Nove blocos de esmalte hígidos e não submetidos a nenhum tipo de tratamento foram utilizados para comparação. As leituras foram realizadas em $\mathrm{mV}$ e os dados foram tabulados em planilha do Excel. Para se obter a concentração de fluoreto de cálcio removido do esmalte controle e das amostras experimentais, dividiuse o valor encontrado pela área exposta $\left(\mu \mathrm{g} F / \mathrm{mm}^{2}\right)$.
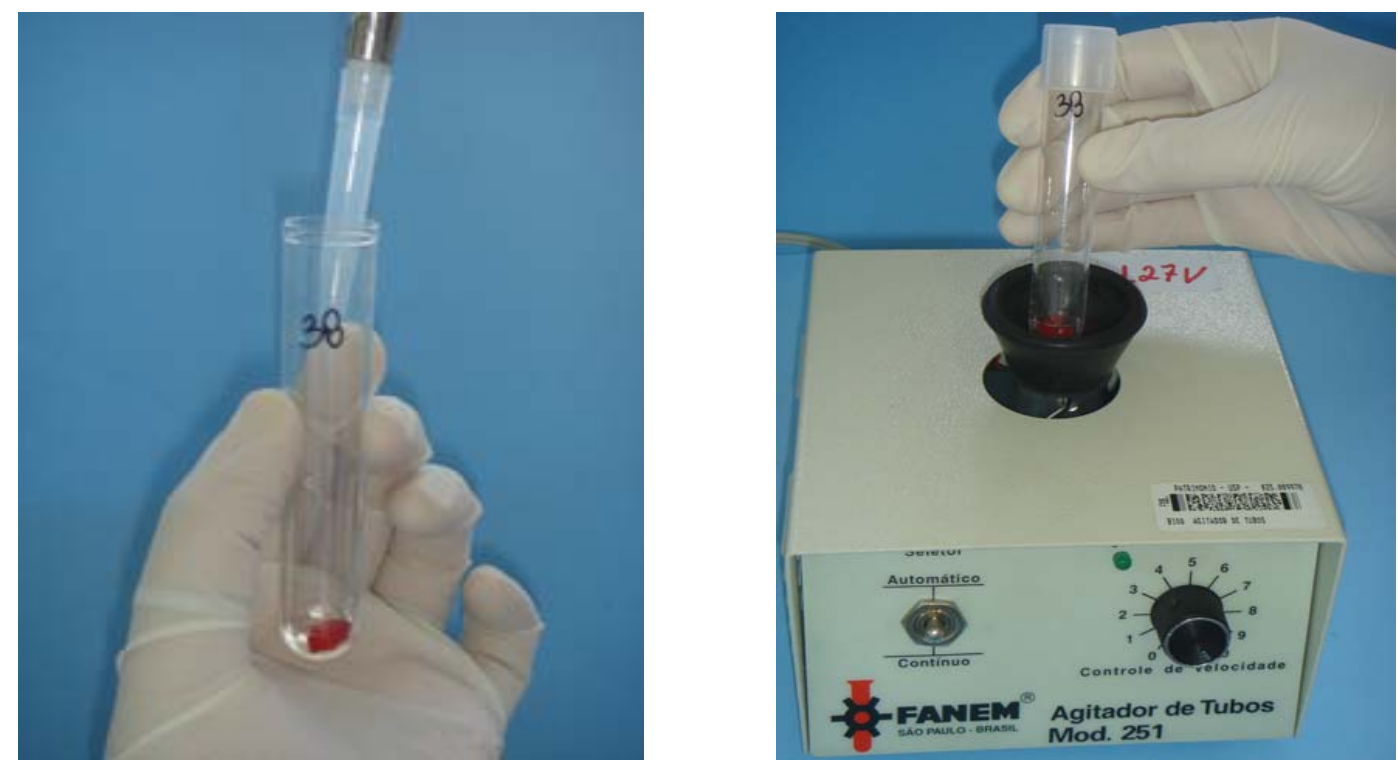

FIGURA 28 - a. Espécime imerso em 0,3 mL de $\mathrm{KOH} \mathrm{1M;} \mathrm{b.} \mathrm{Espécime} \mathrm{sendo} \mathrm{neutralizado}$ com $0,3 \mathrm{~mL}$ de TISAB II

\subsection{Análise estatística}

Os dados foram tabulados em planilhas do Excel e em seguida testado em relação à normalidade e homogeneidade (teste de Kolmogorov and Smirnov), utilizando-se o software GraphPad InsTat. Todos os dados passaram no teste de normalidade e quando a homogeneidade não foi satisfeita, foi feita transformação logarítmica dos mesmos. Os dados referentes à dureza interna foram submetidos à ANOVA de medidas repetidas a 2 critérios (Tratamento e distâncias da superfície), seguida pelo teste de Bonferroni para comparações individuais, utilizando-se o software GraphPad Prism4. Já as outras variáveis foram submetidas à ANOVA de medidas repetidas e teste de Tukey-Kramer para comparações individuais, utilizando-se o software GraphPad InsTat. Diferenças estatisticamente significativas foram consideradas para $p<0,05$. 


$$
5 \text { Resultados }
$$





\section{Resultados}

A Tabela 2 mostra as concentrações médias de $\mathrm{F}$ e Ca presentes na placa dentária para o esmalte hígido e com lesão artificial de cárie. Em relação à concentração de flúor, a ANOVA de medidas repetidas, após transformação logarítmica dos dados, revelou uma diferença significativa entre os grupos (F= 89,40, p<0,0001 e $\mathrm{F}=37,19, \mathrm{p}<0,0001$ para $\mathrm{H}$ e $\mathrm{L}$, respectivamente). O teste de Tukey mostrou que a concentração foi significativamente maior quando o dentifrício fluoretado foi utilizado, sendo que a realização do bochecho com cálcio aumentou significativamente a incorporação de flúor na placa, em cerca de 3 e 6 vezes, para $\mathrm{H}$ e $\mathrm{L}$, respectivamente $(p<0,05)$, em relação à utilização do dentifrício fluoretado associado ao bochecho com água deionizada.

Em relação à concentração de cálcio, a ANOVA de medidas repetidas mostrou uma diferença significativa entre os grupos $(F=38,60, p<0,0001$ e $F=$ 30,52, $p<0,0001$ para $\mathrm{H}$ e L, respectivamente). O teste de Tukey revelou que, no grupo L, a concentração de Ca foi significativamente maior quando o bochecho de $\mathrm{Ca}$ foi realizado, independentemente do tipo de dentifrício associado, embora no grupo $\mathrm{H}$ só tenha havido um aumento significativo da concentração de Ca quando o dentifrício fluoretado foi utilizado. A associação entre bochecho de $\mathrm{Ca}$ e dentifrício fluoretado aumentou significativamente a incorporação de Ca na placa, em cerca de 6 e 4 vezes, para H e L, respectivamente $(p<0,05)$ em relação à utilização de bochecho de Ca associado ao dentifrício placebo. 
TABELA 2 - Concentrações médias ( $\pm E P$ ) de cálcio e flúor presentes na placa dentária sobre o esmalte hígido $(H)$ e com lesão artificial de cárie (L), após tratamento com bochecho de lactato de cálcio $150 \mathrm{mM}$ ou água deionizada (placebo), seguido pelo uso de dentifrício com (1100 ppm) ou sem flúor

\begin{tabular}{ccccc}
\hline \multirow{2}{*}{ Tratamentos* $^{*}$} & \multicolumn{2}{c}{ Concentração de Cálcio $(\mu \mathrm{g} / \mathrm{mg})$} & \multicolumn{2}{c}{ Concentração de Flúor $(\mathrm{ng} / \mathrm{mg})^{\mathrm{**}}$} \\
\cline { 2 - 5 } & $\mathrm{H}$ & $\mathrm{L}$ & $\mathrm{H}$ & $\mathrm{L}$ \\
\hline Placebo & $1,68 \pm 0,34^{\mathrm{a}}$ & $1,76 \pm 0,45^{\mathrm{a}}$ & $14,29 \pm 1,51^{\mathrm{a}}$ & $11,89 \pm 1,50^{\mathrm{a}}$ \\
$\mathrm{Ca}$ & $1,51 \pm 0,32^{\mathrm{a}}$ & $7,17 \pm 2,09^{\mathrm{b}}$ & $16,86 \pm 3,44^{\mathrm{a}}$ & $11,59 \pm 2,48^{\mathrm{a}}$ \\
$\mathrm{F}$ & $3,17 \pm 0,42^{\mathrm{a}}$ & $2,99 \pm 0,36^{\mathrm{a}}$ & $187,24 \pm 44,54^{\mathrm{b}}$ & $176,09 \pm 32,72^{\mathrm{b}}$ \\
$\mathrm{Ca}+\mathrm{F}$ & $9,19 \pm 0,99^{\mathrm{b}}$ & $26,20 \pm 3,63^{\mathrm{c}}$ & $578,70 \pm 82,14^{\mathrm{c}}$ & $1079,10 \pm 184,69^{\mathrm{c}}$ \\
\hline
\end{tabular}

Valores seguidos por letras distintas na mesma coluna são estatisticamente diferentes (ANOVA de medidas repetidas, $p<0,05)$.

*Os tratamentos placebo, $\mathrm{Ca}, \mathrm{F}$ e $\mathrm{Ca}+\mathrm{F}$, referem-se ao uso de bochecho com água deionizada associado a dentifrício placebo, bochecho com lactato de Ca $150 \mathrm{mM}$ associado a dentifrício placebo, bochecho com água deionizada associado a dentifrício fluoretado (1100 ppm) e bochecho com lactato de Ca $150 \mathrm{mM}$ associado a dentifrício fluoretado (1100 ppm), respectivamente.

** Análise baseada em ANOVA de medidas repetidas, após transformação logarítmica dos dados. 
Assim como a concentração de $F$ na placa, a quantidade de $F$ fracamente ligado no esmalte (álcali-solúvel, CaF2) também aumentou significativamente com o uso de dentifrício fluoretado (Tabela 3), tanto para o esmalte hígido $(H)$ quanto para o esmalte com lesão artificial de cárie (L). Porém, o bochecho com cálcio não interferiu nesta incorporação.

A Tabela 3 mostra, outrossim, os resultados de microdureza superficial (\%SMHC). Para o esmalte hígido $(H)$, apesar de haver uma tendência para uma melhor \%SMHC para os grupos que receberam tratamento com cálcio, não houve diferença significativa entre os tratamentos ( $F=1,835, p=0,1648)$.

Para o esmalte com lesão de cárie artificial ( $\mathrm{L}$, \%SMHC média de $72,8 \pm 8,0 \%$ antes da etapa in situ), houve diferenças significativas entre os tratamentos $(F=3,033, p=0,046)$, mas apenas no grupo que recebeu 0 bochecho com $\mathrm{Ca}$ a remineralização foi significativamente melhorada (Ca $67,69 \pm 5,06 \%)$ em comparação ao placebo $(P-48,23 \pm 6,03 \%)(p<0,05)$, apesar de os grupos que receberam dentifrício fluoretado (F- 53,82 \pm 16,30 e Ca+F- 52,98 \pm 8,87) terem tido uma melhor remineralização quando comparados ao grupo placebo $(p>0,05)$. 
TABELA 3 - Concentração média ( $\pm E P$ ) de flúor e \%SMHC média ( $\pm D P$ ) no esmalte hígido $(H)$ e com lesão artificial de cárie (L), após tratamento com bochecho de lactato de cálcio $150 \mathrm{mM}$ ou água deionizada (placebo), seguido pelo uso de dentifrício com (1100 ppm) ou sem flúor

\begin{tabular}{|c|c|c|c|c|}
\hline \multirow[t]{2}{*}{ Tratamentos* } & \multicolumn{2}{|c|}{$\begin{array}{l}\text { Concentração de Flúor } \\
\qquad\left(\mu \mathrm{g} / \mathrm{mm}^{2}\right)\end{array}$} & \multicolumn{2}{|c|}{$\%$ SMHC } \\
\hline & $\mathrm{H}$ & $L$ & $\mathrm{H}$ & $L$ \\
\hline Placebo & $1,42 \pm 0,39^{a}$ & $1,47 \pm 0,32^{a}$ & $-4,87 \pm 6,12^{a}$ & $48,23 \pm 19,08^{a}$ \\
\hline $\mathrm{Ca}$ & $0,78 \pm 0,24^{a}$ & $1,17 \pm 0,49^{a}$ & $-0,85 \pm 8,87^{a}$ & $67,69 \pm 16,01^{b}$ \\
\hline $\mathrm{F}$ & $10,65 \pm 2,90^{b}$ & $8,48 \pm 1,72^{b}$ & $-3,41 \pm 6,87^{a}$ & $53,82 \pm 16,30^{a}$ \\
\hline $\mathrm{Ca}+\mathrm{F}$ & $14,52 \pm 3,60^{b}$ & $9,14 \pm 2,53^{b}$ & $1,74 \pm 5,06^{a}$ & $52,98 \pm 8,87^{a}$ \\
\hline \multicolumn{5}{|c|}{$\begin{array}{l}\text { Valores seguidos por letras distintas na mesma coluna são estatisticamente diferentes } \\
(p<0,05) \text {. }\end{array}$} \\
\hline \multicolumn{5}{|c|}{$\begin{array}{l}\text { *Os tratamentos placebo, Ca, F e Ca+F, referem-se ao uso de bochecho com água deionizada } \\
\text { associado a dentifrício placebo, bochecho com lactato de Ca } 150 \mathrm{mM} \text { associado a dentifrício } \\
\text { placebo, bochecho com água deionizada associado a dentifrício fluoretado ( } 1100 \mathrm{ppm} \text { ) e } \\
\text { bochecho com lactato de Ca } 150 \mathrm{mM} \text { associado a dentifrício fluoretado (1100 ppm), } \\
\text { respectivamente. }\end{array}$} \\
\hline
\end{tabular}


As Tabelas 4 e 5 mostram os resultados da microdureza interna (\% conteúdo mineral) nas diferentes distâncias analisadas para o esmalte hígido (H) e com lesão artificial de cárie (L), respectivamente. Para o esmalte hígido (Tabela 4, Figura 29) submetido à desmineralização in situ, a ANOVA a 2 critérios revelou diferenças significativas entre as distâncias, bem como entre os tratamentos $(F=3,28, p=0,0006)$, não havendo interação significativa entre estes 2 critérios $(F=5,94, p=0,061)$. O teste de Tukey para comparações individuais revelou um conteúdo mineral significantivamente menor em relação às demais distâncias, a $10 \mu \mathrm{m}$ da superfície $(F=40,13, p<0,0001)$. Nesta distância, os grupos que receberam Ca (através do bochecho) ou F (através do dentifrício) apresentaram conteúdos minerais significativamente maiores que o grupo que recebeu bochecho com água deionizada e dentifrício sem $F$, porém sem diferença significativa entre eles. Para as demais distâncias, houve uma redução significativa no conteúdo mineral quando comparada com a distância de $10 \mu \mathrm{m}$, porém sem diferenças significativas entre as distâncias e os tratamentos. 
TABELA 4 - Valores do conteúdo mineral (média, \pm DP) para o esmalte hígido $(\mathrm{H})$, após tratamento com bochecho de lactato de cálcio $150 \mathrm{mM}$ ou água deionizada (placebo), seguido pelo uso de dentifrício com (1100 ppm) ou sem flúor.

\begin{tabular}{|c|c|c|c|c|}
\hline \multirow{2}{*}{$\begin{array}{l}\text { Distâncias da } \\
\text { superfície }(\mu \mathrm{m})\end{array}$} & \multicolumn{4}{|c|}{ Conteúdo mineral (\%vol. Mineral) } \\
\hline & Placebo & $\mathrm{Ca}$ & $\mathrm{F}$ & $\mathrm{Ca}+\mathrm{F}$ \\
\hline 10 & $52,27 \pm 13,00^{a}$ & $71,74 \pm 9,96^{b}$ & $72,45 \pm 14,51^{b}$ & $72,99 \pm 13,03^{b}$ \\
\hline 30 & $83,00 \pm 13,92^{c}$ & $87,30 \pm 8,85^{c}$ & $85,62 \pm 6,35^{c}$ & $84,86 \pm 13,58^{c}$ \\
\hline 50 & $85,11 \pm 13,52^{c}$ & $88,57 \pm 8,81^{c}$ & $87,82 \pm 6,70^{c}$ & $91,51 \pm 6,77^{c}$ \\
\hline 70 & $89,27 \pm 4,20^{c}$ & $87,95 \pm 9,84^{c}$ & $87,92 \pm 7,86^{c}$ & $91,75 \pm 6,54^{c}$ \\
\hline 90 & $89,79 \pm 3,67^{c}$ & $88,50 \pm 9,64^{c}$ & $88,18 \pm 8,25^{c}$ & $92,61 \pm 5,34^{c}$ \\
\hline 110 & $89,57 \pm 4,42^{c}$ & $90,06 \pm 6,51^{\mathrm{c}}$ & $89,95 \pm 7,94^{c}$ & $92,61 \pm 5,13^{c}$ \\
\hline 220 & $88,09 \pm 4,74^{c}$ & $90,01 \pm 6,85^{c}$ & $88,46 \pm 7,76^{\mathrm{c}}$ & $91,85 \pm 5,58^{c}$ \\
\hline 330 & $86,39 \pm 6,14^{c}$ & $89,27 \pm 5,94^{c}$ & $88,01 \pm 8,59^{c}$ & $91,46 \pm 5,37^{c}$ \\
\hline $\begin{array}{c}\text { \%vol. Min } \\
\text { (área integrada) }\end{array}$ & $27728 \pm 1387$ & $28427 \pm 2252$ & $28135 \pm 2257$ & $29140 \pm 1506$ \\
\hline $\begin{array}{l}\text { Valores seguidos } \\
\text { as diferentes distâ } \\
\text { para a área integr } \\
\text { *Os tratamentos } \\
\text { associado a denti } \\
\text { placebo, bochech } \\
\text { bochecho com } \\
\text { respectivamente. }\end{array}$ & $\begin{array}{l}\text { or letras minúsculas } \\
\text { cias e tratamentos. } \\
\text { da ( } p>0,05) \text {. } \\
\text { acebo, } \mathrm{Ca}, \mathrm{F} \text { e Ca+F } \\
\text { ício placebo, boche } \\
\text { com água deioniz } \\
\text { ctato de } \mathrm{Ca} 150\end{array}$ & $\begin{array}{l}\text { distintas são esta } \\
\text { vão houve diferenc } \\
\text {, referem-se ao us } \\
\text { ho com lactato de } \\
\text { ada associado a } \\
\mathrm{mM} \text { associado a }\end{array}$ & $\begin{array}{l}\text { o de bochecho con } \\
\text { Ca } 150 \mathrm{mM} \text { asso } \\
\text { dentifrício fluoreta } \\
\text { dentifrício fluoret }\end{array}$ & $\begin{array}{l}\text { es }(p<0,05) \text { para } \\
\text { e os tratamentos } \\
\text { água deionizada } \\
\text { iado a dentifrício } \\
\text { o }(1100 \mathrm{ppm}) \text { e } \\
\text { do }(1100 \mathrm{ppm}) \text {, }\end{array}$ \\
\hline
\end{tabular}


Para o esmalte com lesão artificial de cárie (Tabela 5, Figura 30), a ANOVA a 2 critérios revelou diferenças significativas entre as distâncias avaliadas mas não entre os tratamentos $(F=0,3, p=0,4)$, tendo havido uma interação significativa entre estes 2 critérios $(F=7,2, p<0,0001)$. O teste de Tukey para comparações individuais revelou um conteúdo mineral significantivamente menor em relação às demais distâncias, a $10 \mu \mathrm{m}$ da superfície $(F=55,1, p<0,0001)$. Nesta distância, para os grupos onde foi utilizado bochecho com $\mathrm{Ca}$, observou-se um conteúdo mineral significativamente maior, não havendo diferença significativa entre eles. À semelhança dos resultados encontrados para o esmalte hígido, para as demais distâncias houve uma redução significativa no conteúdo mineral quando comparada com a distância de $10 \mu \mathrm{m}$, porém sem diferenças significativas entre as distâncias e os tratamentos. Quando foi considerada a área integrada das lesões, não houve diferenças significativas entre os tratamentos, tanto para o esmalte hígido quanto para o esmalte com lesão de cárie artificial. 
TABELA 5 - Valores do conteúdo mineral (média, „DP) para o esmalte com lesão artificial de cárie $(L)$, após tratamento com bochecho de lactato de cálcio $150 \mathrm{mM}$ ou água deionizada (placebo), seguido pelo uso de dentifrício com (1100 ppm) ou sem flúor

\begin{tabular}{ccccc}
\hline \multirow{2}{*}{$\begin{array}{c}\text { Distâncias da } \\
\text { superfície }(\mu \mathrm{m})\end{array}$} & \multicolumn{4}{c}{$\begin{array}{c}\text { Conteúdo mineral (\%vol. Mineral) } \\
\text { Tratamentos* }\end{array}$} \\
\cline { 2 - 5 } & Placebo & Ca & $\mathrm{F}$ & Ca+F \\
\hline 10 & $58,06 \pm 14,29^{\mathrm{a}}$ & $73,71 \pm 9,28^{\mathrm{b}}$ & $63,80 \pm 13,36^{\mathrm{a}}$ & $74,09 \pm 11,33^{\mathrm{b}}$ \\
30 & $84,79 \pm 5,74^{\mathrm{c}}$ & $89,69 \pm 3,97^{\mathrm{c}}$ & $87,26 \pm 5,24^{\mathrm{c}}$ & $84,65 \pm 8,12^{\mathrm{c}}$ \\
50 & $89,94 \pm 6,26^{\mathrm{c}}$ & $90,24 \pm 3,86^{\mathrm{c}}$ & $89,16 \pm 4,23^{\mathrm{c}}$ & $89,07 \pm 4,33^{\mathrm{c}}$ \\
70 & $90,83 \pm 5,80^{\mathrm{c}}$ & $89,86 \pm 4,39^{\mathrm{c}}$ & $90,91 \pm 4,63^{\mathrm{c}}$ & $88,40 \pm 4,65^{\mathrm{c}}$ \\
90 & $91,60 \pm 4,48^{\mathrm{c}}$ & $88,92 \pm 4,47^{\mathrm{c}}$ & $91,22 \pm 4,03^{\mathrm{c}}$ & $88,40 \pm 5,05^{\mathrm{c}}$ \\
110 & $91,75 \pm 4,75^{\mathrm{c}}$ & $90,70 \pm 4,54^{\mathrm{c}}$ & $90,79 \pm 4,79^{\mathrm{c}}$ & $88,37 \pm 5,47^{\mathrm{c}}$ \\
220 & $91,57 \pm 3,83^{\mathrm{c}}$ & $89,19 \pm 3,03^{\mathrm{c}}$ & $90,39 \pm 4,13^{\mathrm{c}}$ & $87,54 \pm 6,04^{\mathrm{c}}$ \\
330 & $90,5 \pm 5,48^{\mathrm{c}}$ & $86,75 \pm 4,43^{\mathrm{c}}$ & $89,47 \pm 3,33^{\mathrm{c}}$ & $86,30 \pm 6,73^{\mathrm{c}}$ \\
\hline \%vol. Min & $28737 \pm 1400$ & $28389 \pm 1103$ & $28574 \pm 1306$ & $27871 \pm 1738$ \\
\hline (área integrada) & & & & \\
\hline
\end{tabular}

Valores seguidos por letras minúsculas distintas são estatisticamente diferentes $(p<0,05)$ para as diferentes distâncias e tratamentos. Não houve diferenças significativas entre os tratamentos para a área integrada $(p>0,05)$.

*Os tratamentos placebo, $\mathrm{Ca}, \mathrm{F}$ e Ca+F , referem-se ao uso de bochecho com água deionizada associado a dentifrício placebo, bochecho com lactato de Ca $150 \mathrm{mM}$ associado a dentifrício placebo, bochecho com água deionizada associado a dentifrício fluoretado (1100 ppm) e bochecho com lactato de Ca $150 \mathrm{mM}$ associado a dentifrício fluoretado (1100 ppm), respectivamente. 


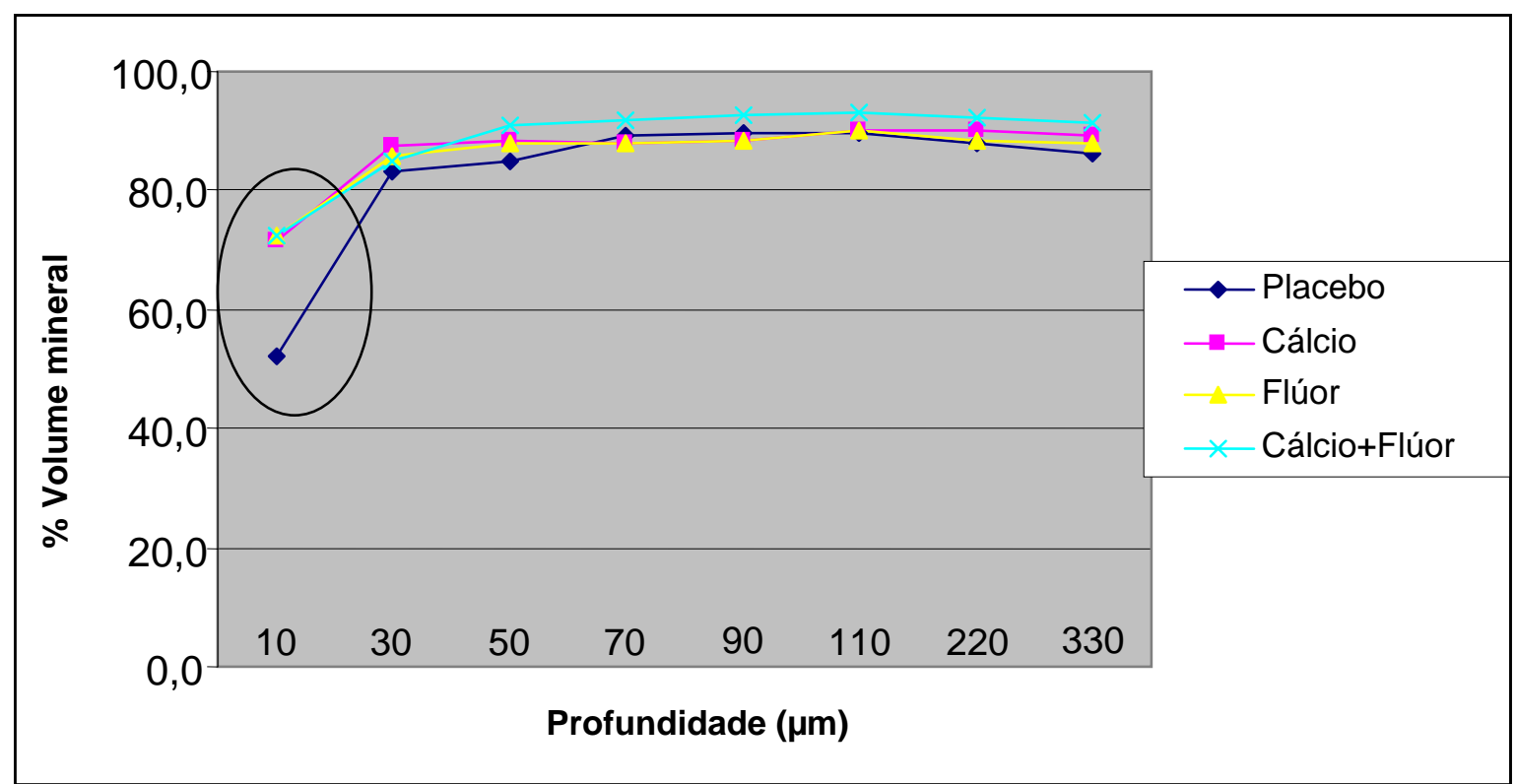

FIGURA 29 - Média da \% volume mineral nas diferentes profundidades para o esmalte hígido. Só houve diferenças significativas entre os grupos a $10 \mu \mathrm{m}$ da superfície, onde nos grupos tratados houve um aumento significativo no conteúdo mineral quando comparados ao placebo. 


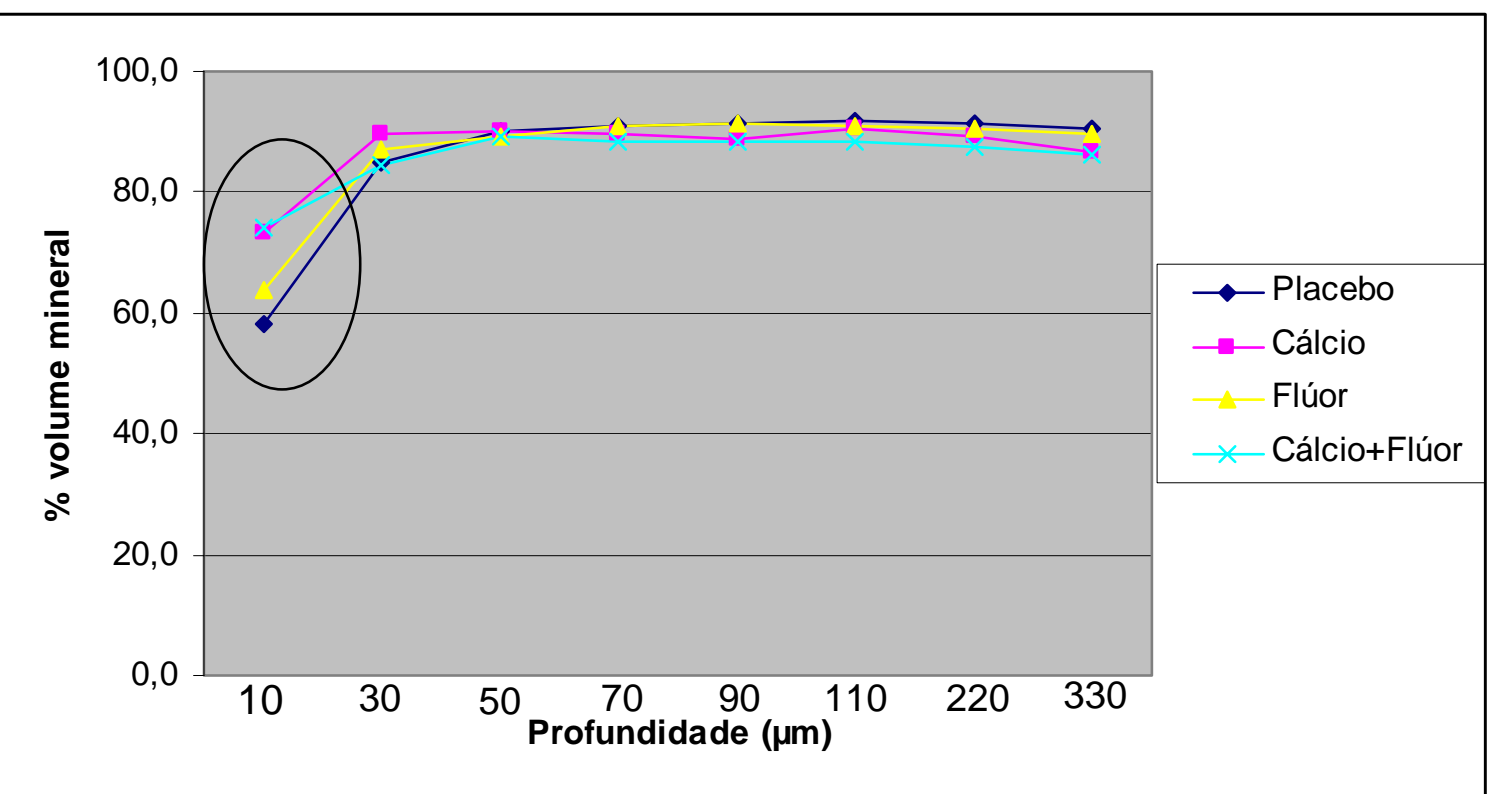

FIGURA 30 - Média da \% volume mineral nas diferentes profundidades para o esmalte com lesão artificial de cárie. Só houve diferenças significativas entre os grupos a $10 \mu \mathrm{m}$ da superfície, onde os grupos que realizaram bochecho com Ca (Cálcio e Cálcio + Flúor) apresentaram conteúdo mineral significativamente maior que os grupos que realizaram bochecho com água deionizada (placebo e flúor). 


\section{Discussão}





\section{Discussão}

A escovação com dentifrício fluoretado é uma importante medida preventiva para a cárie dentária, não somente pela remoção mecânica da placa, mas também pela ação do F. Estudos clínicos têm mostrado uma relação inversa entre a concentração de $F$ na placa e a incidência de cárie dentária (ARENDS; CHRISTOFFERSEN ${ }^{5}$, 1990; AOBA; FEJARESKOV², 2002; AMMARI et al. ${ }^{4}$, 2003). É certo que a incorporação de $F$ na placa é dependente da concentração de Ca existente (AST; FITZGERALD ${ }^{11}$, 1962; BLAYNEY; HILL $^{15}$, 1967; BLOCH-ZUPAN ${ }^{16}$, 2001; WHITFORD et al. ${ }^{120}$, 2002; AXELSSON $^{12}$, 2004; WHITFORD et al. ${ }^{117}$, 2005; PESSAN et al. $\left.{ }^{73}, 2006\right)$. Por isso, muitos estudos têm testado o efeito da aplicação de Ca previamente ao $\mathrm{F}$ sobre a incorporação de $\mathrm{F}$ na placa. Vários são os sais $\left(\mathrm{CaCl}_{2}\right.$, fosfato tri-cálcio e lactato de cálcio) e veículos (soluções para bochecho, chicletes e dentifrícios) utilizados para este fim. Neste estudo, utilizou-se a solução de lactato de cálcio a $150 \mathrm{mM}$, conforme descrito por VOGEL et al. ${ }^{113}$ (2006) e PESSAN et al. ${ }^{73}$ (2006). Nossos resultados demonstraram claramente esta relação entre Ca e $\mathrm{F}$, de acordo com os resultados de VOGEL et al. ${ }^{112}$ (2005) e PEARCE et al. ${ }^{71}$ (1999) para o fluido da placa e de VOGEL et al. ${ }^{113}$ (2006) para a placa total. VOGEL et al. ${ }^{113}$ (2006) mostraram in vivo um aumento em 10 vezes na concentração de $\mathrm{F}$ na placa quando foi realizado um bochecho com lactato de cálcio a $150 \mathrm{mM}$ previamente a um bochecho com NaF (228 ppm F) em relação ao grupo sem bochecho com Ca (controle). É interessante ressaltar que no nosso trabalho este aumento foi menor (3-6 vezes). Três hipóteses poderiam tentar explicar esta diversidade, sendo uma delas as diferenças metodológicas, uma vez que nosso estudo foi realizado in situ, utilizando um volume de solução e freqüência de bochecho com Ca diferente de VOGEL et al. ${ }^{113}$ (2006), além do que o veículo fluoretado no nosso estudo foi o dentifrício, enquanto que no de VOGEL et al. ${ }^{113}$, (2006) foi uma solução para bochecho. A $2^{\mathrm{a}}$ hipótese seria que o nosso controle foi bochecho com água de abastecimento, que tem em média $0,7 \mathrm{ppm}$ de $\mathrm{F}$. O F da água pode ter colaborado na incorporação de $F$ pela placa do grupo controle. A última 
hipótese seria que a coleta no trabalho de VOGEL et al. ${ }^{113}$ (2006) foi realizada 1 hora após o experimento, enquanto no nosso trabalho foi realizada após 12 horas. Tem-se relatado que a concentração de $\mathrm{F}$ na placa após a utilização de dentifrício fluoretado diminui significativamente entre 1 e 12 horas seguidas à escovação (WHITFORD et al. ${ }^{117,120}, 2002,2005$; PESSAN et al. ${ }^{73}, 2006$ ).

Nos estudos de VOGEL et al. ${ }^{112,113}$ (2005; 2006), o veículo fluoretado utilizado foi a solução para bochecho. Como o dentifrício fluoretado é o veículo mais utilizado pela população, foi testado recentemente em nosso laboratório, in vivo, o efeito do bochecho com Lactato de cálcio a $150 \mathrm{mM}$ antes da escovação com dentifrício fluoretado na incorporação de F pela placa dentária após 1 e 12 horas da aplicação. No entanto, nenhum aumento adicional na incorporação de F na placa foi encontrado quando o bochecho com $\mathrm{Ca}$ foi utilizado em associação ao dentifrício fluoretado, tanto 1 quanto 12 horas após a aplicação dos agentes (PESSAN et al. ${ }^{73}$, 2006). O estudo de PESSAN et al. 73 (2006) não utilizou o gotejamento da solução de dentifrício (1:3) em cima da placa que foi posteriormente coletada, mas sim a escovação dos dentes durante 7 dias, sendo que no último dia foi realizada escovação somente na superfície oclusal dos dentes, para permitir a coleta da placa na superfície vestibular. Neste caso, portanto, a espessura da placa formada foi pequena e não houve incorporação de Ca e F contínuas, como no presente estudo, o que poderia explicar os diferentes achados. Vale ressaltar que nos estudos de VOGEL et al. ${ }^{112,113}(2005 ; 2006)$ acima descritos, o tratamento com Ca e F também foi realizado uma só vez, mas mesmo assim houve um efeito significativo do Ca para aumentar a incorporação de F. A diferença entre os achados de PESSAN et al. ${ }^{73}$ (2006) e VOGEL et al. ${ }^{113}$ (2006) foi explicada principalmente pelo tipo de agente fluoretado utilizado, já que PESSAN et al. ${ }^{73}$ (2006) utilizaram dentifrício fluoretado e VOGEL et al. ${ }^{113}$ (2006), solução de bochecho. O lauril-sulfato de sódio presente no dentifrício poderia reagir com 0 Ca da solução de bochecho, desta maneira reduzindo a quantidade deste disponível para reagir com e reter o $\mathrm{F}$ na placa (PESSAN et al. ${ }^{73}$, 2006). Também a presença de lauril-sulfato de sódio no dentifrício utilizado no presente estudo poderia ajudar a explicar o menor incremento na concentração de F na placa após a utilização de dentifrício fluoretado (3-6 vezes), quando 
comparado com o trabalho de VOGEL et al. ${ }^{113}$ (2006), após a utilização de bochecho fluoretado (10 vezes).

Quanto à concentração de Ca presente na placa, a mesma foi significativamente maior quando o bochecho de Ca esteve associado ao uso de dentifrício fluoretado, sendo que esta associação aumentou significativamente a incorporação de Ca na placa, em cerca de 6 e 4 vezes, para o esmalte hígido e com lesão inicial de cárie, respectivamente, em relação à utilização de Ca isoladamente. Isto nos mostra a relação de dependência entre os íons Ca e F, como vem sendo extensivamente relatado na literatura (AST; FITZGERALD ${ }^{11}$, 1962; BLAYNEY; HILL ${ }^{15}$, 1967; BLOCH-ZUPAN ${ }^{16}$, 2001; WHITFORD et al. ${ }^{120}$, 2002; AXELSON ${ }^{12}$, 2004; WHITFORD et al. ${ }^{117}$, 2005; PESSAN et al. ${ }^{73}$, 2006). Quando se realizou um bochecho com $\mathrm{Ca}$ e em seguida escovação com dentifrício fluoretado, houve um aumento significativo da concentração de íons Ca e F na placa, em comparação ao uso dos mesmos agentes isoladamente ( $p$ $<0,05)$, em concordância com PEARCE et al. ${ }^{71}$ (1999) e BLAKE-HASKINS et al. $^{14}$ (1992). O uso apenas do bochecho com Ca aumentou significativamente a incorporação de Ca pela placa do esmalte com lesão de cárie. No entanto, para o esmalte hígido, isto não ocorreu. A hipótese para justificar este fato é que com o desafio cariogênico ao qual foi submetido o esmalte hígido, com a produção de ácido e conseqüentemente baixo $\mathrm{pH}, \mathrm{o} \mathrm{Ca}$ aderido à placa dentária (bactérias e matriz extra-celular) teria sido disponibilizado e incorporado à superfície do esmalte, diminuindo sua concentração na placa e ao mesmo tempo, promovendo a reformação da apatita. Com a sua incorporação na apatita, houve uma diminuição não significativa da perda de dureza superficial $(p>0,05)$, mas significativa para a dureza interna a $10 \mu \mathrm{m}$ da superfície $(p<0,05)$. Por que isto não ocorreu para o esmalte com lesão de cárie? Provavelmente porque não foi realizado desafio cariogênico. E por que isto não ocorreu quando o Ca esteve associado ao F? Provavelmente neste caso também houve uma liberação dos íons Ca e F da placa para o esmalte e isto pode explicar a sua ação nas durezas superficial e interna. No entanto, como houve formação de $\mathrm{CaF}_{2}$, um produto relativamente insolúvel, as quedas de $\mathrm{pH}$ devem ter sido insuficientes para hidrolisar este composto e diminuir expressivamente a concentração destes íons na placa dentária. Isto poderia explicar o fato de a concentração de $\mathrm{F}$ no esmalte não ter aumentado com a 
associação entre $\mathrm{Ca}$ e $\mathrm{F}$, bem como não ter havido diferença significativa na dureza interna entre tratamentos. De fato, no presente estudo optou-se pela realização de um protocolo in situ a fim de que pudesse ser avaliado se as alterações causadas na composição iônica da placa dentária em virtude da realização de um bochecho com Ca previamente à utilização de um agente fluoretados seriam refletidas no conteúdo mineral do esmalte dentário subjacente a esta placa. Este foi o primeiro estudo onde tanto a composição iônica da placa dentária quanto o conteúdo mineral do esmalte foram avaliados simultaneamente face aos tratamentos com Ca seguido por $F$, já que os estudos prévios (WHITFORD et al. ${ }^{117}$, 2005; PESSAN et al. ${ }^{73}$, 2006; VOGEL et al. $^{112,113}$, 2005; 2006) analisaram apenas o conteúdo iônico da placa dentária ou apenas o conteúdo mineral do esmalte dentário in vitro (BLAKE-HASKINS et al. $\left.^{14}, 1992\right)$ face a estes tratamentos.

Assim como a concentração de $F$ na placa, a quantidade de $F$ fracamente ligado no esmalte (álcali-solúvel, $\mathrm{CaF}_{2}$ ) aumentou significativamente com o uso de dentifrício fluoretado (Tabela 3), tanto para o esmalte hígido quanto para o esmalte com lesão artificial de cárie. Porém, o bochecho com Ca não interferiu nesta incorporação. É sabido que a formação de $\mathrm{CaF}_{2}$ advém da dupla reação entre o $\mathrm{F}$ presente no agente aplicado e o $\mathrm{Ca}$ proveniente da ligeira dissolução do esmalte em conseqüência ao $\mathrm{pH}$ do agente. Assim, têm sido descritas algumas estratégias para aumentar a formação de $\mathrm{CaF}_{2}$ no esmalte: aumentar a concentração de $\mathrm{F}$ no agente fluoretado, diminuir o seu pH ou aumentar o tempo de exposição (TEN CATE ${ }^{93}$, 1999). No presente estudo, poder-se-ia imaginar que a utilização de um bochecho com Ca (especialmente sendo a solução utilizada cerca de 50 vezes mais concentrada que a saliva, ou seja, lactato de Ca $150 \mathrm{mM}$ ) previamente ao uso do dentifrício fluoretado, pudesse aumentar a concentração de Ca disponível para reagir com o F do dentifrício, aumentando, desta forma, a quantidade de $\mathrm{CaF}_{2}$ formado no esmalte. No entanto, isto não ocorreu. Também é sabido que a formação do $\mathrm{CaF}_{2}$ depende do tempo de contato do agente fluoretado com o esmalte, especialmente em condições de $\mathrm{pH}$ neutro (TEN CATE $\left.{ }^{93}, 1999\right)$, como é o caso do dentifrício fluoretado. Então, é possível que o pequeno tempo de exposição ao dentifrício fluoretado, associado ao seu $\mathrm{pH}$ neutro, não tenham permitido um efeito significativo da solução de Ca. 
Quando se analisa a \% SMHC, para o esmalte hígido, apesar de haver uma tendência para uma melhor \%SMHC para os grupos que receberam tratamento com cálcio, não houve diferença significativa entre os tratamentos. Convém ressaltar que a \%SMHC para o esmalte hígido, submetido à formação da lesão de cárie in situ, foi muito pequena. Isto se deve provavelmente ao baixo desafio cariogênico utilizado (3 aplicações de sacarose $20 \%$ por dia, durante 14 dias). É possível que se tivesse sido empregado um desafio cariogênico maior (aplicação de sacarose 20\% 8 vezes ao dia, por exemplo) ou sido aumentado o período experimental para 28 dias, os resultados tivessem sido diferentes. Para o esmalte com lesão de cárie artificial, houve diferenças significativas entre os tratamentos, mas apenas no grupo que recebeu 0 bochecho com $\mathrm{Ca}$, a remineralização interna foi significativamente melhorada em comparação ao placebo, apesar de os grupos que receberam dentifrício fluoretado terem tido uma melhor remineralização quando comparado ao grupo placebo. A hipótese para justificar isso é que, na presença do $F$, houve formação de $\mathrm{CaF}_{2}$ e deposição deste composto na placa. Isto pode ser comprovado na Tabela 2, que mostra uma maior concentração de Ca e F na placa para o grupo que recebeu bochecho com Ca e dentifrício fluoretado. Em adição, um estudo recente realizado pelo nosso grupo de pesquisa (PESSAN et al. ${ }^{73}$, 2006) propôs um mecanismo de 4 passos para a incorporação de $\mathrm{F}$ na placa a partir do dentifrício fluoretado e outros produtos de alta concentração de F (Figura 1). O produto de solubilidade do fluoreto de cálcio seria excedido em uma ordem de magnitude após o uso de um dentifrício com 1000 ppm de F (primeiro passo), o que levaria à formação de altas concentrações de $\mathrm{CaF}_{2}$, relativamente insolúvel e pobremente difusível nos fluidos bucais (segundo passo). Este composto diminuiria a probabilidade de o F iônico migrar para o interior da placa e ao invés disto se acumularia na interface entre a saliva e as superfícies bucais, estabelecendo, desta forma, uma barreira de difusão para o F iônico. Este segundo passo é consistente com dados recentes mostrando que a incorporação de $\mathrm{F}$ durante uma breve aplicação tópica é largamente restrita às camadas superficiais da placa (WATSON et al. ${ }^{114}$, 2005). No terceiro passo, os compostos de $\mathrm{CaF}_{2}$ começam a se dissociar, conforme a concentração de F no ambiente diminui devido ao clearance salivar. Alguns íons $\mathrm{F}$ e $\mathrm{Ca}$ migram de volta para a saliva e regiões internas da placa (quarto 
passo), de uma maneira consistente com a segunda fase do processo de duas fases proposto por DUCKWORTH; MORGAN ${ }^{30}$ (1991) e DUCKWORTH; STEWART $^{32}$ (1994). Assim, o $\mathrm{CaF}_{2}$ formado na superfície da placa em grandes concentrações após a utilização de um bochecho com Ca seguido pelo uso do dentifrício fluoretado, impediria a migração do Ca e F iônico para porções mais internas da placa e para o esmalte, diminuindo o efeito remineralizador do cálcio. Em adição, os episódios de queda de $\mathrm{pH}$ que poderiam resultar na quebra do $\mathrm{CaF}_{2}$, para que o $\mathrm{F}$ e $\mathrm{Ca}$ pudessem ser incorporados ao esmalte, aumentando a sua dureza, foram restritos. 


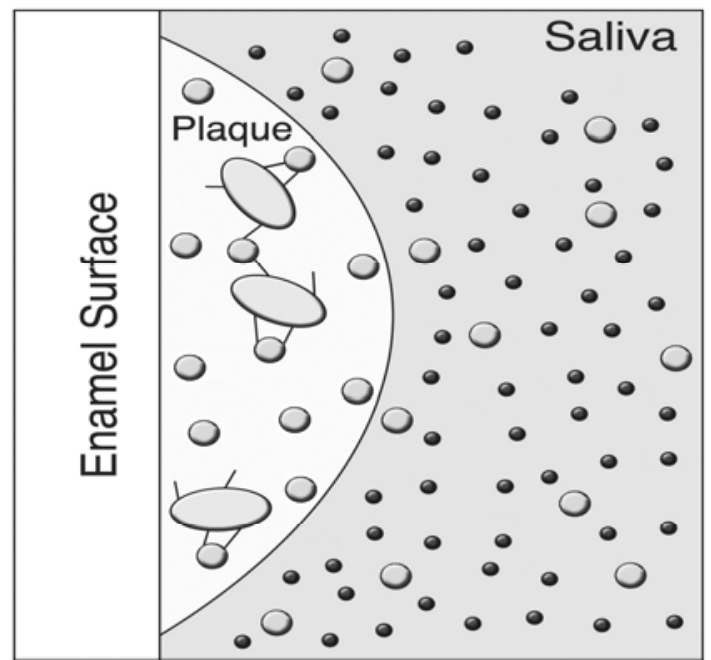

A

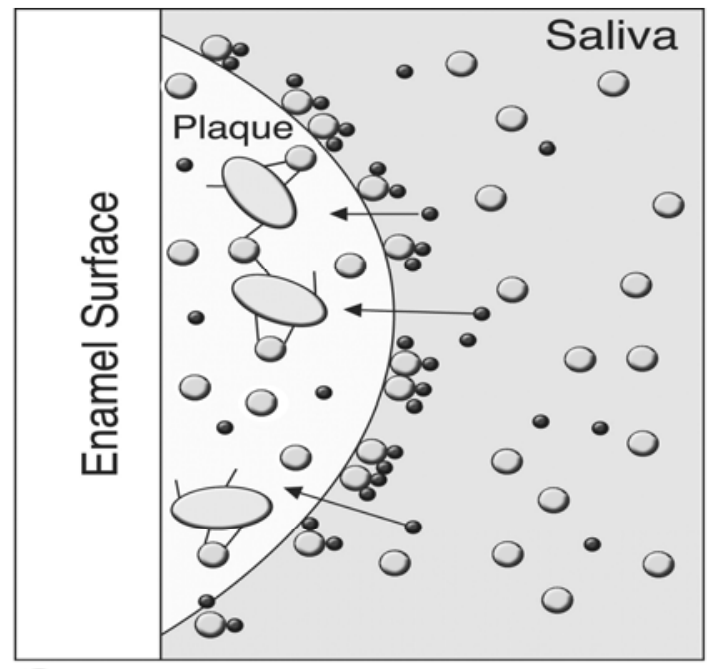

C

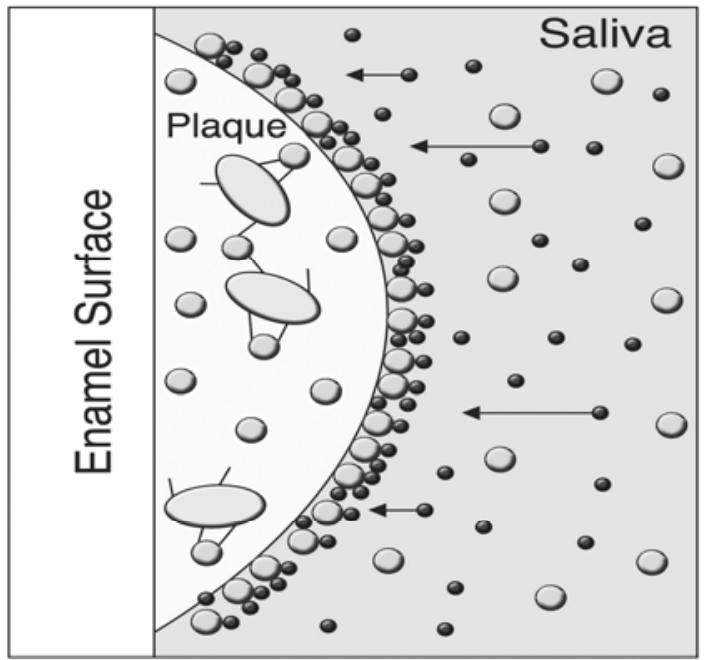

B

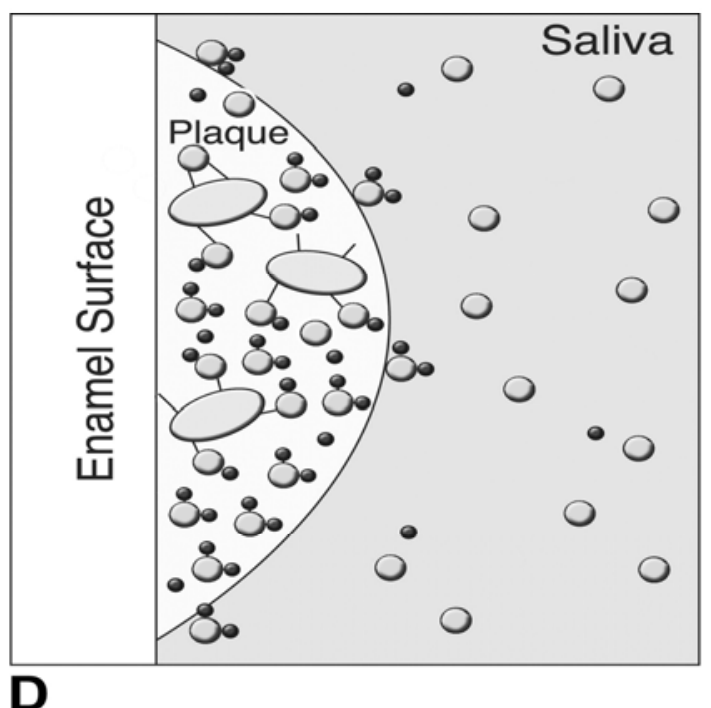

FIGURA 30 - Mecanismo de quatro passos proposto para a incorporação de $\mathrm{F}$ na placa pelo uso de dentifrício fluoretado. (A) Durante o uso de dentifrício, altas concentrações de $\mathrm{F}$ e Ca na saliva excedem o produto de solubilidade do $\mathrm{CaF}_{2}$. (B) $\mathrm{O}$ acúmulo de $\mathrm{CaF}_{2}$, principalmente na interface saliva-placa, limita a penetração de $F$ iônico dentro das regiões mais profundas da placa. Este passo limitante não ocorreria com uma menor concentração de $F$ como a encontrada na água de beber. (C) Como a concentração de $\mathrm{F}$ diminui devido ao clearance salivar, o $\mathrm{CaF}_{2}$ dissocia-se permitindo a penetração de uma parte do $\mathrm{F}$ para as camadas mais profundas da placa. (D) O F se liga ao Ca intrínseco o qual está ligado à superfície da bactéria e presente no espaço extra-celular. Círculos claros e escuros representam o $\mathrm{Ca}$ e o $\mathrm{F}$, respectivamente. Figuras elípticas representam as bactérias da placa dentária (Pessan et al., 2007). 
Com relação aos dados da microdureza interna, para o esmalte com lesão artificial de cárie, houve um aumento significativo no conteúdo mineral a $10 \mu \mathrm{m}$ da superfície, quando os grupos experimentais foram comparados ao placebo, embora os grupos experimentais não tenham diferido significativamente entre si. Nas demais distâncias da superfície, não houve diferenças significativas entre os grupos placebo e experimentais. BLAKEHASKINS et al. ${ }^{14}$ (1992) mostraram in vitro que o tratamento do esmalte com cálcio $\left(\mathrm{CaCl}_{2}, 180\right.$ ppm, 10 minutos) previamente ao flúor (NaF, 100 ppm, 10 minutos) seguido por desafio cariogênico (16 horas de desmineralização, 7 horas e 40 minutos de remineralização por 5 dias) reduziu o grau de formação da lesão (micro-radiografia) em 90\% (solução fluoretada) e em 46\% (dentifrício fluoretado) em comparação ao tratamento somente com o flúor (68\% para a solução e 32\% para o dentifrício, respectivamente). Interessante é que este estudo suporta a hipótese de PESSAN et al. ${ }^{73}$ (2006) que a presença de certos componentes no dentifrício (lauril-sulfato de sódio) diminua seu potencial para a incorporação de $\mathrm{F}$ pela placa em comparação à solução, podendo reduzir seu potencial anti-cariogênico, como foi visto no estudo de BLAKE-HASKINS et al. $^{14}$ (1992). O mesmo resultado foi encontrado por PEARCE e NELSON ${ }^{72}$ (1988) em um trabalho in situ no qual eles compararam o uso de uma solução de bochecho enriquecida por $\mathrm{Ca}, \mathrm{P}$ e $\mathrm{F}$ com o uso do dentifrício apenas na redução da desmineralização do esmalte. A solução reduziu a desmineralização do esmalte em 76\%, enquanto que o dentifrício apenas reduziu em 67\%. Em contraste, no nosso estudo não pôde ser comprovada maior efetividade na associação do Ca e F em comparação ao uso de $\mathrm{F}$ apenas, provavelmente pelas diferenças no delineamento e no tipo de análise dos dois trabalhos.

Já para o esmalte com lesão artificial de cárie, na distância de $10 \mu \mathrm{m}$ da superfície, somente os tratamentos com $\mathrm{Ca}(\mathrm{Ca}$ e $\mathrm{Ca}+\mathrm{F})$ foram melhores que o placebo, a $10 \mu \mathrm{m}$ da superfície. Nas outras distâncias, não houve diferenças significativas entre os grupos. Chama a atenção o fato de o comportamento do esmalte hígido submetido à formação de cárie in situ ter sido diferente do comportamento do esmalte com lesão artificial de cárie. Para o esmalte hígido, houve um efeito significativo do $F$ na inibição da desmineralização. A hipótese para se justificar isto é que, mesmo tendo sido feito um baixo desafio 
cariogênico (sacarose 20\%, 3 vezes ao dia), houve 3 episódios de redução de $\mathrm{pH}$ da placa por dia, que podem ter contribuído para a disponibilização do $\mathrm{F}$ que estava ligado ao $\mathrm{Ca}$ na placa e no esmalte, na forma de $\mathrm{CaF}_{2}$. Isto não ocorreu para os blocos com lesão arificial de cárie, que apenas sofreram remineralização e não foram expostos a desafios cariogênicos. Assim, como as concentrações de Ca na saliva e na placa são muito maiores que as de $\mathrm{F}$, quando do uso do dentifrício fluoretado apenas (sem associação com bochecho de $\mathrm{Ca}$ ) o $\mathrm{F}$ do dentifrício deve ter se complexado com o $\mathrm{Ca}$ e ficado imobilizado na forma de $\mathrm{CaF}_{2}$, que não se dissolveu subseqüentemente devido à ausência de quedas de pH. Quando da aplicação do Ca (sozinho, ou associado ao dentifrício fluoretado), uma grande parte do mesmo deve ter ficado livre para atingir o esmalte e atuar no processo de remineralização, o que deve ter levado à melhor performance dos tratamentos com Ca.

Em relação ao cálculo integral da porcentagem de volume mineral preconizado por FEATHERSTONE et al. $^{35}$ (1983), não se verificou diferença significativa entre os tratamentos para os dois tipos substratos de esmalte. Para o esmalte hígido submetido à formação de cárie in situ, este resultado se deve ao fato de que a lesão de cárie formada foi muito pequena, devido ao baixo desafio cariogênico, atingindo somente $10 \mu \mathrm{m}$ da superfície interna. $A$ ação dos tratamentos foi encontrada somente para esta distância. Quando se utilizou a fórmula considerando todas as distâncias, este efeito foi diluído, fazendo que os grupos não se apresentassem diferença significativa. Já para o esmalte com lesão artificial de cárie, a remineralização durante 14 dias, mesmo no grupo placebo, fez com que a lesão fosse diminuída e se restringisse à superfície externa e aos $10 \mu \mathrm{m}$ da superfície interna. Isto mostra o importante papel da saliva. Nas distâncias acima citadas foi possível diferenciar estatisticamente os grupos, sendo que o grupo do Ca teve melhor efeito em comparação aos outros grupos. Como as superfícies mais internas foram remineralizadas, esta diferença também foi diluída.

Os resultados analisados em conjunto sugerem que, em situações de baixo desafio cariogênico, a realização de um bochecho com Ca previamente à utilização de dentifrício fluoretado, apesar de aumentar significativamente a incorporação de F na placa dentária não produz um efeito benéfico adicional no conteúdo mineral do esmalte. Seria interessante a realização de um estudo 
onde os espécimes contendo lesão de cárie artificial fossem submetidos também a um desafio cariogênico durante a etapa in situ, a fim de se avaliar se nesta situação haveria um aumento significativo no conteúdo mineral do esmalte dentário quando da associação entre bochecho com Ca e dentifrício fluoretado. Da mesma maneira, seria interessante que fosse conduzido um estudo onde blocos de esmalte hígidos fossem submetidos in situ a situações de alto desafio cariogênico (sacarose 20\% 8 vezes ao dia), a fim de que se pudesse avaliar se a realização de bochechos com Ca previamente à utilização de dentifrício fluoretado seria uma boa estratégia para se reduzir a perda mineral do esmalte em pacientes com alto risco de cárie. 


\section{Conclusões}





\section{Conclusões}

Com base nos resultados apresentados por este protocolo de estudo, podemos concluir que:

1- A utilização de dentifrício fluoretado diminuiu significativamente o grau de desmineralização do esmalte dental bovino (a $10 \mu \mathrm{m}$ da superfície) submetido a uma situação de desafio cariogênico in situ, mas não alterou a dureza superficial. Houve alteração ainda na composição iônica da placa bacteriana (F) formada sobre o esmalte e na quantidade de F álcali-solúvel presente no esmalte;

2- A utilização de dentifrício fluoretado não alterou o grau de remineralização (superficial e interna) in situ do esmalte dental bovino com lesão de cárie inicial. No entanto, alterou a composição iônica da placa bacteriana $(\mathrm{F})$ formada sobre este esmalte e a quantidade de $\mathrm{F}$ álcali-solúvel no esmalte;

3- A realização de um bochecho com lactato de cálcio previamente à utilização do dentifrício fluoretado não alterou o grau de desmineralização (superficial e interna) do esmalte dental bovino hígido submetido a uma situação de desafio cariogênico in situ, bem como a quantidade de $\mathrm{F}$ álcali-solúvel no esmalte. No entanto, alterou a composição iônica da placa bacteriana formada sobre este esmalte ( $\mathrm{F} \mathrm{e}$ $\mathrm{Ca}$ );

4- A realização de um bochecho com lactato de cálcio previamente à utilização do dentifrício fluoretado aumentou significativamente o grau de remineralização in situ do esmalte dental bovino com lesão de cárie inicial a $10 \mu \mathrm{m}$ da superfície, bem como a composição iônica da placa bacteriana ( $\mathrm{F} \mathrm{e} \mathrm{Ca}$ ) formada sobre este esmalte. No entanto, não alterou a quantidade de $\mathrm{F}$ álcali-solúvel no esmalte.

Estas conclusões permitem a rejeição de todas as hipóteses nulas formuladas. 
Anexos 



\section{Anexos}

Anexo 1

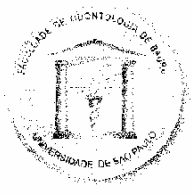

\section{Universidade de São Paulo \\ Faculdade de Odontologia de Bauru}

Al. Dr. Octávio Pinheiro Brisolla, 9-75 - Bauru-SP - CEP 17012-901 - C.P. 73 PABX (0XX14)3235-8000 - FAX (0XX14)3223-4679

Comitê de Éfico em Pesquiso (3235-8350)

Of: $n^{\circ}$ CEP/O5 2004/FOB

Bauru, 02 de abril de 2004.

Senhora Professora,

Informamos que após análise por este Comitê de Ética em Pesquisa em Seres Humanos, a alteração do título do projeto de pesquisa intitulado “Efeito de cátions na dureza do esmalte bovino e na composicáo da placa bacteriana formada in situ" de autoria da Cleide Cristina Rodrigues Martinhon desenvolvido sob sua orientação, para "Efeito do ferro na composição do esmalte bovino e da placa dentária formada in situ", foi aprovado considerando que não houve modificação em sua metodologia.

Lembramos que após o enuio do trabalho conchuido, este Comitê envián o parecer final, que será utilizado para a publicação do trabalho.

Atenciosamente,

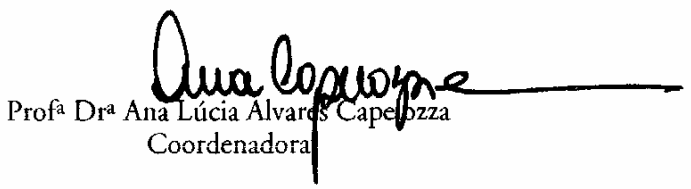

Ilma Sra Profa Dra Marília $\Lambda$ fonso Rabelo Buzalaf

DD. Docente do Departamento de Ciências Biológicas (Disciplina de Bioquímica) 


\section{Anexo 2}

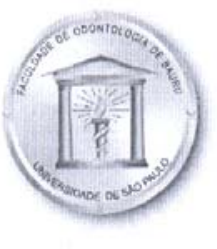

\section{Universidade de São Paulo Faculdade de Odontologia de Bauru}

Al. Dr. Octávio Pinheiro Brisolla, 9-75 - Bauru-SP - Brasil - CEP $17012-901$ - C.P. 73 PABX (0XX14)3235-8000-FAX (0XX14)3223-4679

Comitê de Ética em Pesquisa (3235-8356)

Of. ${ }^{\circ}$ CEP/30 2006/FOB

Bauru, 04 de dezembro de 2006.

Senhora Professora,

Após análise da solicitaçăo de Vossa Senhoria, este Colegiado aprovou "ad referendum" a realização do segundo subprojeto originário do trabalho de pesquisa "Efeito de cátions na dureza do esmalte bovino e na composiçāo da placa bacteriana formada in situ", nesta etapa conduzido pela C.D. Tatiana de Almeida Furlani sob sua orientaçăo, intitulado "Efeito do lactato de cálcio aplicado previamente ao dentifrício fluoretado na desmineralização do esmalte bovino e na composição da placa bacteriana formada in situ", considerando que năo houve modificação em sua metodologia.

Solicitamos o envio de um relatório com os resultados obtidos, para análise final, que será utilizado na publicaçăo em periódicos científicos.

Atenciosamente,

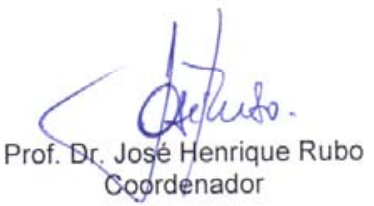

Profa Dra Marília Afonso Rabelo Buzalaf

Docente do Departamento de Ciência Biológicas 


\section{Anexo 3}

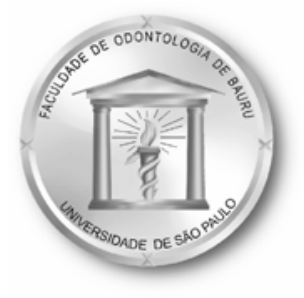

\section{Universidade de São Paulo Faculdade de Odontologia de Bauru}

Al. Dr. Octávio Pinheiro Brisolla, 9-75 - Bauru-SP - CEP 17012-901 - C.P. 73

PABX (0XX14)235-8000 - FAX (0XX14)223-4679

Carta de Informação ao Voluntário

Nome do voluntário:

As informações contidas nesta carta serão fornecidas pela aluna Tatiana de Almeida Furlani, sob a orientação da Profa. Dra. Marília Afonso Rabelo Buzalaf, com o intuito de informar o voluntário sobre a natureza dos procedimentos a que se submeterá ao participar da pesquisa, com a capacidade de livre arbítrio e sem qualquer coação.

\section{1 - Título do Trabalho Experimental}

"Estudo in situ do efeito do cálcio aplicado previamente ao flúor na des e remineralização do esmalte dental bovino e na composição iônica da placa bacteriana."

\section{2 - Objetivo}

O objetivo deste estudo cruzado e cego in situ é verificar o efeito do Ca e do F na redução da desmineralização e no aumento da remineralização do esmalte dental bovino e na composição da placa bacteriana.

\section{3 - Procedimentos da Fase Experimental}

Este estudo será realizado in situ, no qual você participará utilizando aparelhos intrabucais palatinos, contendo quatro blocos de esmalte de incisivos bovinos, previamente esterilizados em formol a 10\%, divididos em 2 fileiras. O estudo será composto por quatro fases, com duração de 14 dias por fase, com intervalo de uma semana entre cada uma delas, de tal modo que ao final você terá passado por todos os tratamentos.

Você utilizará o aparelho diariamente, inclusive para dormir, removendo-o apenas para as três principais refeições (3 vezes ao dia, 1h/refeição).

Após cada refeição ( $\underline{3 x / d i a})$, com o aparelho fora da boca, você gotejará uma solucão de sacarose a $10 \%$ na fileira com cera de cor verde (3 gotas/bloco, 2 blocos, total de 6 gotas). Após 5 minutos, você recolocará o aparelho na boca e fará um bochecho com $10 \mathrm{~mL}$ da solucão de cálcio, durante 1 minuto. Em seguida, você removerá o aparelho e gotejará a solução de dentifrício nos quatro blocos da fileira verde e amarela (3 gotas/ bloco, total de 12 gotas). Enquanto você aguarda 1 minuto, deverá escovar seus dentes de forma habitual com o dentifrício cedido pela autora. A quantidade de dentifrício deverá ser mínima, apenas uma pequena mancha, conforme ilustrado na foto. Quando completar 1 minuto, deverá recolocar o aparelho na boca e realizar um bochecho com $10 \mathrm{~mL}$ de água da torneira, durante 
5 segundos. Segue abaixo a foto do aparelho (Figura 1) que será utilizado pelos voluntários e o resumo dos procedimentos que deverão ser realizados 3 x/dia.

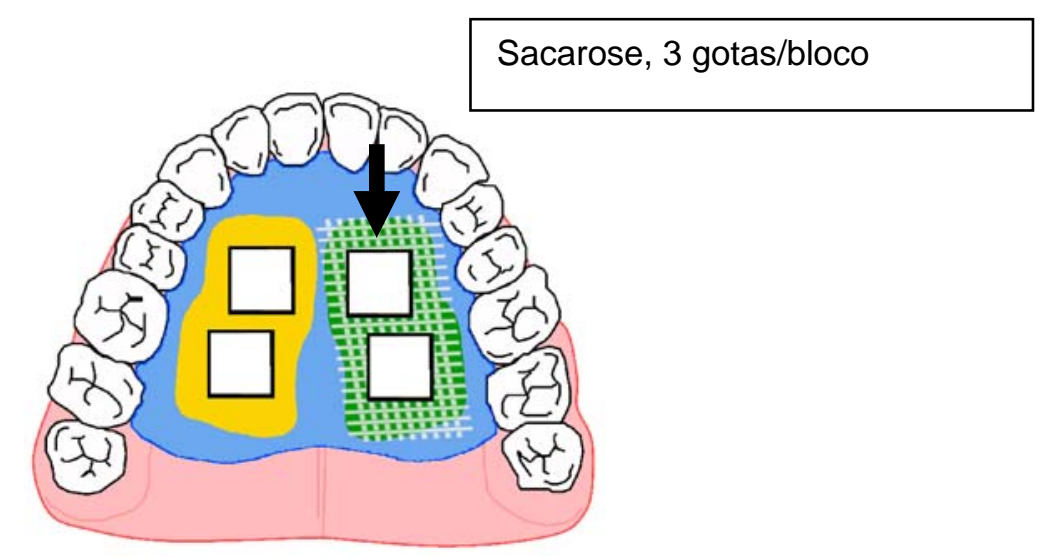

Figura 1 - Foto do aparelho

\section{ETAPAS}

\begin{tabular}{|l|l|}
\hline 1- Sacarose 10\% & Gotejar sobre os blocos da fileira verde (3 gotas/ bloco) e esperar 5 min. \\
\hline 2- Sol. de calcio & Com o aparelho na boca, fazer um bochecho com 10mL, durante 1 min. \\
\hline 3- Sol. de dentifrício & Gotejar sobre os 4 blocos das fileiras verde e amarela (3 gotas/ bloco) \\
\hline 4 - Escovação & $\begin{array}{l}\text { Durante 1 min, escovar seus dentes com o dentifrício sem enxaguar (Figura } \\
\text { 2). }\end{array}$ \\
\hline 5- Enxágüe & $\begin{array}{l}\text { Em seguida, recolocar o aparelho e fazer um bochecho com 10 mL de } \\
\text { água, durante 5 s. }\end{array}$ \\
\hline
\end{tabular}

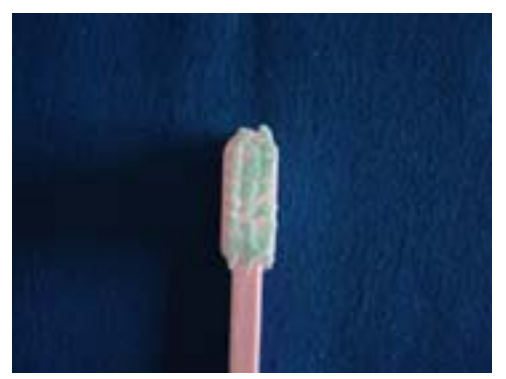

Figura 2 - Quantidade de dentifrício que deve ser colocado na escova ("sujeirinha")

\section{4 - Benefícios do Experimento}

Espera-se fornecer dados laboratoriais quanto à ação do cálcio e flúor na formação e remineralização de esmalte hígido e previamente desmineralizado, respectivamente. 


\section{$\underline{5}$ - Informações}

Os voluntários terão a garantia de receber esclarecimento de qualquer dúvida acerca dos procedimentos, riscos, benefícios e outros assuntos relacionados com a pesquisa. Qualquer dúvida ou problema (na falta de materiais ou queda da tela ou bloco do aparelho), os participantes poderão entrar em contato com a autora do projeto - Tatiana de Almeida Furlani - Telefone (14) 3227-1680 ou (14) 8124-9340, ou no telefone (14) 3235-8246. Caso queira apresentar reclamações em relação a sua participação na pesquisa, poderá entrar em contato com o Comitê de Ética em Pesquisa em Seres Humanos, da FOB-USP, pelo endereço da Al. Octávio Pinheiro Brisolla, 9-75 (sala no prédio da Biblioteca, FOB-USP) ou pelo telefone (14) 32358356.

Por estarem entendidos e de acordo com a presente carta de informação,

Nome do voluntário

\section{Assinatura do responsável}




\section{Anexo 4}

\section{Universidade de São Paulo Faculdade de Odontologia de Bauru}

Al. Dr. Octávio Pinheiro Brisolla, 9-75 - Bauru-SP - CEP 17012-901 - C.P. 73

PABX (0XX14)235-8000 - FAX (0XX14)223-4679

\section{TERMO DE CONSENTIMENTO LIVRE E ESCLARECIDO}

Pelo presente instrumento que atende às exigências legais, o senhor(a)

portador(a) da cédula de identidade após leitura

minuciosa da CARTA DE INFORMAÇÃO AO VOLUNTÁRIO, devidamente explicada pelos profissionais em seus mínimos detalhes, ciente dos procedimentos aos quais será submetido, não restando quaisquer dúvidas a respeito do lido e explicado, firma seu CONSENTIMENTO LIVRE E ESCLARECIDO concordando em participar da pesquisa proposta.

Fica claro que o voluntário pode a qualquer momento retirar seu CONSENTIMENTO LIVRE E ESCLARECIDO e deixar de participar desta pesquisa e ciente de que todas as informações prestadas tornaram-se confidenciais e guardadas por força de sigilo profissional (Art. $9^{\circ}$ do Código de Ética Odontológica).

Por estarem de acordo assinam o presente termo.

Bauru, de de 


\section{Anexo 5}

Dados de microdureza superficial (SMH e \%SMHC) de acordo com a aleatorização realizada

\begin{tabular}{|c|c|c|c|c|c|c|c|}
\hline \multicolumn{4}{|c|}{ BLOCOS HÍGIDOS } & \multicolumn{4}{|c|}{ BLOCOS COM LESÃO DE CÁRIE } \\
\hline Voluntários & Fases* & Número & $\mathrm{SMH}$ & Voluntários & Fases* & Número & $\% \mathrm{SMHC}$ \\
\hline 1 & 1 & 400 & 348 & 1 & 1 & 97 & 62,92 \\
\hline 1 & 1 & 355 & 362 & 1 & 1 & 402 & 86,33 \\
\hline 1 & 2 & 396 & 339 & 1 & 2 & 40 & 65,62 \\
\hline 1 & 2 & 372 & 357 & 1 & 2 & 156 & 79,93 \\
\hline 1 & 3 & 350 & 329 & 1 & 3 & 6 & 62,88 \\
\hline 1 & 3 & 314 & 364 & 1 & 3 & 246 & 79,62 \\
\hline 1 & 4 & 370 & 331 & 1 & 4 & 202 & 61,53 \\
\hline 1 & 4 & 321 & 353 & 1 & 4 & 177 & 81,2 \\
\hline 2 & 1 & 452 & 347 & 2 & 1 & 52 & 64,91 \\
\hline 2 & 1 & 361 & 364 & 2 & 1 & 164 & 84,49 \\
\hline 2 & 2 & 446 & 332 & 2 & 2 & 126 & 69,91 \\
\hline 2 & 2 & 391 & 361 & 2 & 2 & 85 & 73,2 \\
\hline 2 & 3 & 405 & 351 & 2 & 3 & 219 & 66,94 \\
\hline 2 & 3 & 389 & 366 & 2 & 3 & 159 & 81,16 \\
\hline 2 & 4 & 440 & 348 & 2 & 4 & 398 & 70,3 \\
\hline 2 & 4 & 418 & 368 & 2 & 4 & 413 & 74,14 \\
\hline 3 & 1 & 431 & 343 & 3 & 1 & 38 & 62,56 \\
\hline 3 & 1 & 311 & 354 & 3 & 1 & 205 & 72,48 \\
\hline 3 & 2 & 423 & 344 & 3 & 2 & 7 & 63 \\
\hline 3 & 2 & 364 & 364 & 3 & 2 & 117 & 88,9 \\
\hline 3 & 3 & 349 & 342 & 3 & 3 & 133 & 65,68 \\
\hline 3 & 3 & 449 & 368 & 3 & 3 & 235 & 84,85 \\
\hline 3 & 4 & 363 & 344 & 3 & 4 & 189 & 66,16 \\
\hline 3 & 4 & 432 & 372 & 3 & 4 & 179 & 88,17 \\
\hline 4 & 1 & 319 & 341 & 4 & 1 & 131 & 65,73 \\
\hline 4 & 1 & 309 & 369 & 4 & 1 & 231 & 80,71 \\
\hline 4 & 2 & 365 & 329 & 4 & 2 & 190 & 64,35 \\
\hline 4 & 2 & 380 & 366 & 4 & 2 & 90 & 75,3 \\
\hline 4 & 3 & 346 & 349 & 4 & 3 & 109 & 68,51 \\
\hline 4 & 3 & 382 & 352 & 4 & 3 & 166 & 84,07 \\
\hline 4 & 4 & 374 & 340 & 4 & 4 & 136 & 63,82 \\
\hline 4 & 4 & 377 & 367 & 4 & 4 & 79 & 86,33 \\
\hline 5 & 1 & 419 & 320 & 5 & 1 & 147 & 69,69 \\
\hline 5 & 1 & 356 & 369 & 5 & 1 & 184 & 75,63 \\
\hline 5 & 2 & 437 & 318 & 5 & 2 & 230 & 68,98 \\
\hline 5 & 2 & 385 & 356 & 5 & 2 & 187 & 77,06 \\
\hline 5 & 3 & 459 & 326 & 5 & 3 & 13 & 64,48 \\
\hline 5 & 3 & 448 & 354 & 5 & 3 & 417 & 86,96 \\
\hline 5 & 4 & 339 & 319 & 5 & 4 & 176 & 68,82 \\
\hline 5 & 4 & 352 & 359 & 5 & 4 & 106 & 81,14 \\
\hline 6 & 1 & 462 & 327 & 6 & 1 & 16 & 63,69 \\
\hline 6 & 1 & 428 & 356 & 6 & 1 & 243 & 79,77 \\
\hline
\end{tabular}




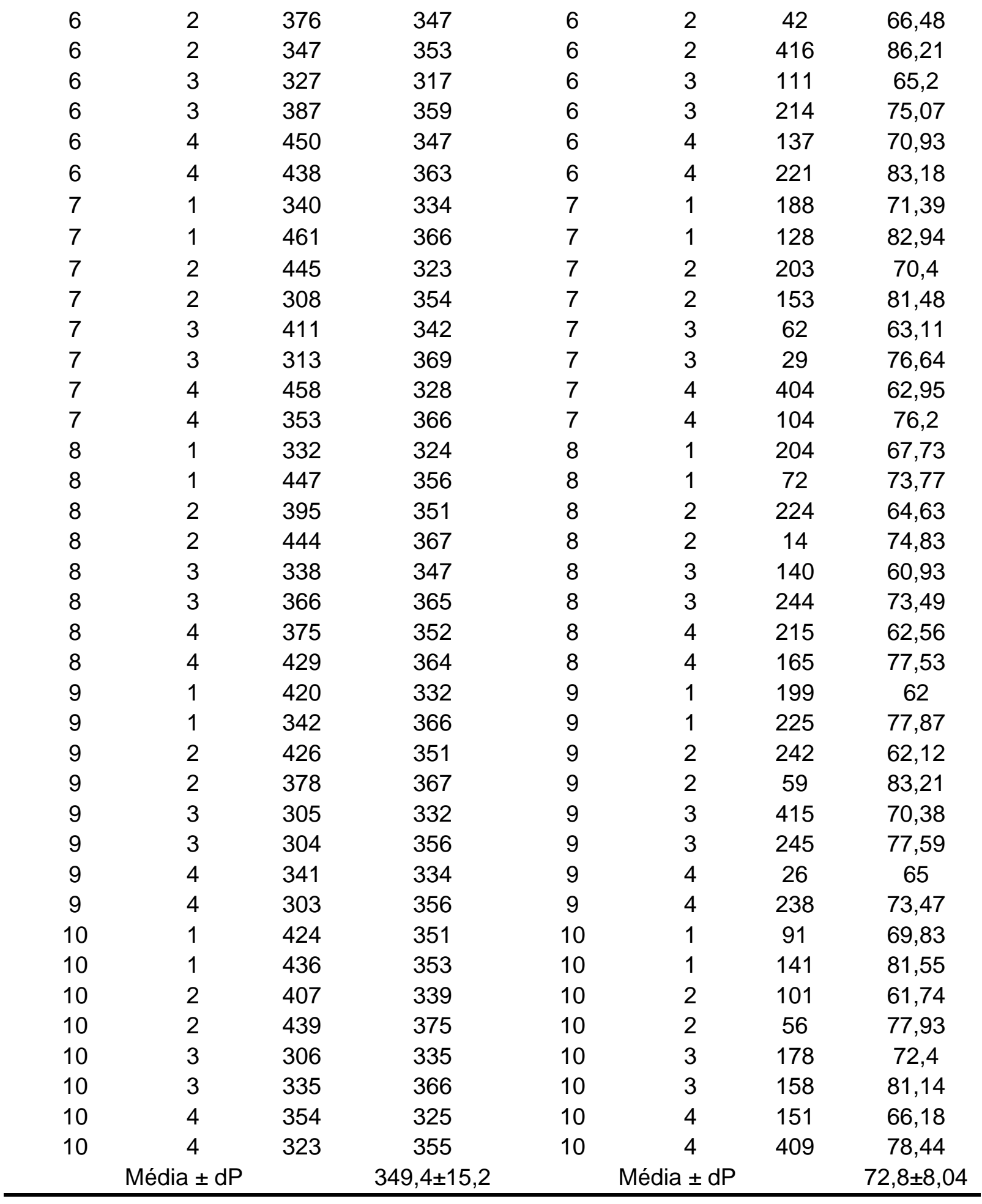




\section{Anexo 6}

\section{DIÁRIO DE PESQUISA}

Nome: Fase:

Data: 1 a 1

\begin{tabular}{|c|c|c|c|c|}
\hline Data & Freqüência & Horário & Procedimento & Horário \\
\hline \multirow[t]{15}{*}{$1^{\circ} \mathrm{dia}$} & Café & & Sacarose & \\
\hline & & & Calcio & \\
\hline & & & Sol.de dentifrício & \\
\hline & & & Escovação & \\
\hline & & & Enxágüe & \\
\hline & Almoco & & Sacarose & \\
\hline & & & Calcio & \\
\hline & & & Sol.de dentifrício & \\
\hline & & & Escovação & \\
\hline & & & Enxágüe & \\
\hline & Jantar & & Sacarose & \\
\hline & & & Calcio & \\
\hline & & & Sol.de dentifrício & \\
\hline & & & Escovação & \\
\hline & & & Enxágüe & \\
\hline \multirow[t]{15}{*}{$2^{\circ} \mathrm{dia}$} & Café & & Sacarose & \\
\hline & & & Calcio & \\
\hline & & & Sol.de dentifrício & \\
\hline & & & Escovação & \\
\hline & & & Enxágüe & \\
\hline & Almoço & & Sacarose & \\
\hline & & & Calcio & \\
\hline & & & Sol.de dentifrício & \\
\hline & & & Escovação & \\
\hline & & & Enxágüe & \\
\hline & Jantar & & Sacarose & \\
\hline & & & Calcio & \\
\hline & & & Sol.de dentifrício & \\
\hline & & & Escovação & \\
\hline & & & Enxágüe & \\
\hline \multirow[t]{11}{*}{$3^{\circ} \mathrm{dia}$} & Café & & Sacarose & \\
\hline & & & Calcio & \\
\hline & & & Sol.de dentifrício & \\
\hline & & & Escovação & \\
\hline & & & Enxágüe & \\
\hline & Almoço & & Sacarose & \\
\hline & & & Calcio & \\
\hline & & & Sol.de dentifrício & \\
\hline & & & Escovação & \\
\hline & & & Enxágüe & \\
\hline & Jantar & & Sacarose & \\
\hline
\end{tabular}




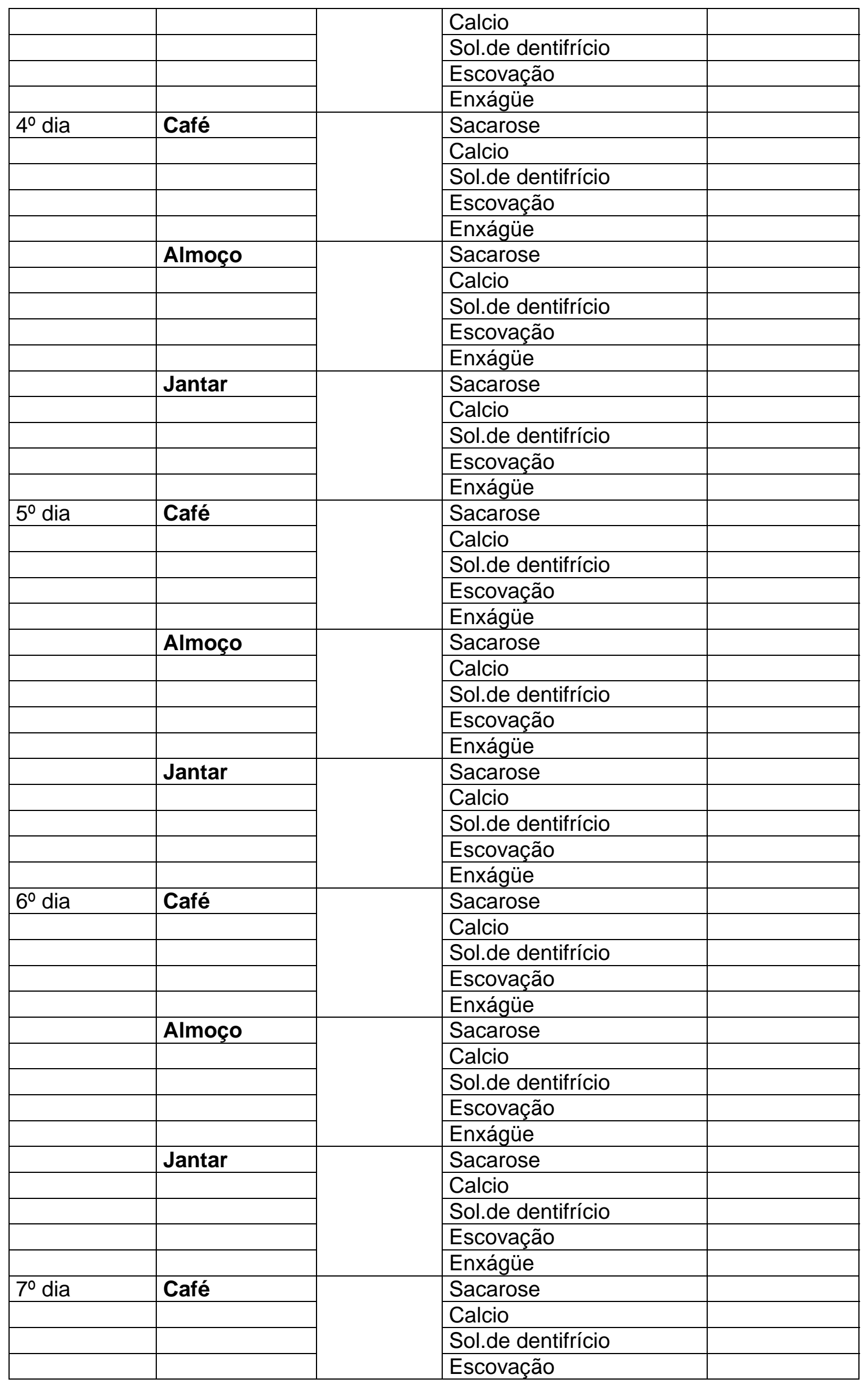




\begin{tabular}{|c|c|c|c|}
\hline & & Enxágüe & \\
\hline & Almoço & Sacarose & \\
\hline & & Calcio & \\
\hline & & Sol.de dentifrício & \\
\hline & & Escovação & \\
\hline & & Enxágüe & \\
\hline & Jantar & Sacarose & \\
\hline & & Calcio & \\
\hline & & Sol.de dentifrício & \\
\hline & & Escovação & \\
\hline & & Enxágüe & \\
\hline $8^{\circ} \mathrm{dia}$ & Café & Sacarose & \\
\hline & & Calcio & \\
\hline & & Sol.de dentifrício & \\
\hline & & Escovação & \\
\hline & & Enxágüe & \\
\hline & Almoço & Sacarose & \\
\hline & & Calcio & \\
\hline & & Sol.de dentifrício & \\
\hline & & Escovação & \\
\hline & & Enxágüe & \\
\hline & Jantar & Sacarose & \\
\hline & & Calcio & \\
\hline & & Sol.de dentifrício & \\
\hline & & Escovação & \\
\hline & & Enxágüe & \\
\hline $9^{\circ} \mathrm{dia}$ & Café & Sacarose & \\
\hline & & Calcio & \\
\hline & & Sol.de dentifrício & \\
\hline & & Escovação & \\
\hline & & Enxágüe & \\
\hline & Almoço & Sacarose & \\
\hline & & Calcio & \\
\hline & & Sol.de dentifrício & \\
\hline & & Escovação & \\
\hline & & Enxágüe & \\
\hline & Jantar & Sacarose & \\
\hline & & Calcio & \\
\hline & & Sol.de dentifrício & \\
\hline & & Escovação & \\
\hline & & Enxágüe & \\
\hline $10^{\circ}$ dia & Café & Sacarose & \\
\hline & & Calcio & \\
\hline & & Sol.de dentifrício & \\
\hline & & Escovação & \\
\hline & & Enxágüe & \\
\hline & Almoço & Sacarose & \\
\hline & & Calcio & \\
\hline & & Sol.de dentifrício & \\
\hline & & Escovação & \\
\hline & & Enxágüe & \\
\hline & Jantar & Sacarose & \\
\hline & & Calcio & \\
\hline
\end{tabular}




\begin{tabular}{|c|c|c|c|}
\hline & & Sol.de dentifrício & \\
\hline & & Escovação & \\
\hline & & Enxágüe & \\
\hline \multirow[t]{15}{*}{$11^{\circ}$ dia } & Café & Sacarose & \\
\hline & & Calcio & \\
\hline & & Sol.de dentifrício & \\
\hline & & Escovação & \\
\hline & & Enxáqüe & \\
\hline & Almoço & Sacarose & \\
\hline & & Calcio & \\
\hline & & Sol.de dentifrício & \\
\hline & & Escovação & \\
\hline & & Enxágüe & \\
\hline & Jantar & Sacarose & \\
\hline & & Calcio & \\
\hline & & Sol.de dentifrício & \\
\hline & & Escovação & \\
\hline & & Enxágüe & \\
\hline \multirow[t]{15}{*}{$12^{\circ}$ dia } & Café & Sacarose & \\
\hline & & Calcio & \\
\hline & & Sol.de dentifrício & \\
\hline & & Escovação & \\
\hline & & Enxágüe & \\
\hline & Almoço & Sacarose & \\
\hline & & Calcio & \\
\hline & & Sol.de dentifrício & \\
\hline & & Escovação & \\
\hline & & Enxágüe & \\
\hline & Jantar & Sacarose & \\
\hline & & Calcio & \\
\hline & & Sol.de dentifrício & \\
\hline & & Escovação & \\
\hline & & Enxágüe & \\
\hline \multirow[t]{15}{*}{$13^{\circ}$ dia } & Café & Sacarose & \\
\hline & & Calcio & \\
\hline & & Sol.de dentifrício & \\
\hline & & Escovação & \\
\hline & & Enxágüe & \\
\hline & Almoço & Sacarose & \\
\hline & & Calcio & \\
\hline & & Sol.de dentifrício & \\
\hline & & Escovação & \\
\hline & & Enxágüe & \\
\hline & Jantar & Sacarose & \\
\hline & & Calcio & \\
\hline & & Sol.de dentifrício & \\
\hline & & Escovação & \\
\hline & & Enxágüe & \\
\hline \multirow[t]{5}{*}{$14^{\circ}$ dia } & Café & Sacarose & \\
\hline & & Calcio & \\
\hline & & Sol.de dentifrício & \\
\hline & & Escovação & \\
\hline & & Enxágüe & \\
\hline
\end{tabular}




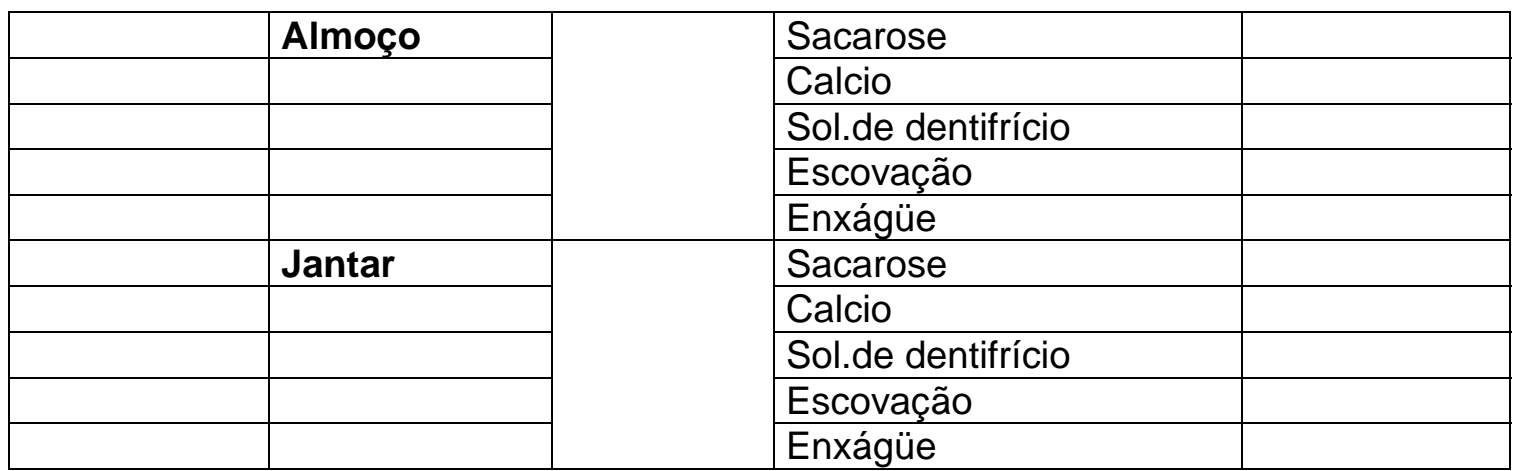




\section{Anexo 7}

Padrões de Flúor para Análise da Biopsia Básica

\begin{tabular}{|c|c|}
\hline $\begin{array}{l}\text { Para o BLANK } \\
0,3 \mathrm{~mL} \text { de } \mathrm{KOH} \mathrm{M} \\
0,3 \mathrm{~mL} \text { de TISAB II (HCl) }\end{array}$ & $\begin{array}{l}\text { 0,025 ppm } \mathbf{F} \\
0,15 \mathrm{~mL} \text { de padrão de } 0,1 \text { ppm } \\
0,15 \mathrm{~mL} \text { de } \mathrm{KOH} 2 \mathrm{M} \\
0,3 \mathrm{~mL} \text { de TISAB II }(\mathrm{HCl})\end{array}$ \\
\hline $\begin{array}{l}\text { 0,05 ppm F } \\
0,15 \text { mL de padrão de } 0,2 \text { ppm } \\
0,15 \mathrm{~mL} \text { de } \mathrm{KOH} 2 \mathrm{M} \\
0,3 \mathrm{~mL} \text { de TISAB II (HCl) }\end{array}$ & $\begin{array}{l}\mathbf{0 , 1} \mathbf{p p m} \mathbf{F} \\
0,15 \mathrm{~mL} \text { de padrão de } 0,4 \text { ppm } \\
0,15 \mathrm{~mL} \text { de } \mathrm{KOH} 2 \mathrm{M} \\
0,3 \mathrm{~mL} \text { de TISAB II (HCl) }\end{array}$ \\
\hline $\begin{array}{l}\text { 0,2 ppm F } \\
0,15 \mathrm{~mL} \text { de } \mathrm{KOH} 2 \mathrm{M} \\
0,15 \mathrm{~mL} \text { de } \mathrm{KOH} 2 \mathrm{M} \\
0,3 \mathrm{~mL} \text { de TISAB II }(\mathrm{HCl})\end{array}$ & $\begin{array}{l}\mathbf{0 , 4} \mathbf{p p m} \mathbf{F} \\
0,15 \mathrm{~mL} \text { de padrão de } 1,6 \text { ppm } \\
0,15 \mathrm{~mL} \text { de } \mathrm{KOH} 2 \mathrm{M} \\
0,3 \mathrm{~mL} \text { de TISAB II }(\mathrm{HCl})\end{array}$ \\
\hline $\begin{array}{l}\text { 0,8 ppm F } \\
0,15 \text { mL de padrão de 3,2 ppm } \\
0,15 \text { mL de } \mathrm{KOH} 2 \mathrm{M} \\
0,3 \mathrm{~mL} \text { de TISAB II (HCl) }\end{array}$ & $\begin{array}{l}\text { 1,6 ppm } \mathbf{F} \\
0,15 \mathrm{~mL} \text { de padrão de } 6,4 \text { ppm } \\
0,15 \mathrm{~mL} \text { de } \mathrm{KOH} 2 \mathrm{M} \\
0,3 \mathrm{~mL} \text { de TISAB II }(\mathrm{HCl})\end{array}$ \\
\hline $\begin{array}{l}\text { 3,2 ppm F } \\
0,15 \text { mL de padrão de } 12,8 \text { ppm } \\
0,15 \mathrm{~mL} \text { de } \mathrm{KOH} 2 \mathrm{M} \\
0,3 \mathrm{~mL} \text { de TISAB II }(\mathrm{HCl})\end{array}$ & $\begin{array}{l}\text { Teste } \\
0,15 \mathrm{~mL} \text { de padrão de } 1,6 \mathrm{ppm} \\
0,15 \mathrm{~mL} \text { de } \mathrm{KOH} 2 \mathrm{M} \\
0,3 \mathrm{~mL} \text { de TISAB II }(\mathrm{HCl})\end{array}$ \\
\hline
\end{tabular}




$$
\begin{aligned}
& \text { Referências } \\
& \text { Bibliográficas }
\end{aligned}
$$




\section{Referências Bibliográficas}

1. Aires CP, et al. Effect of sucrose concentration on dental biofilm formed in situ on enamel demineralization. Caries Res. 2006;40(1):28-32.

2. Aoba T, Fejerskov O. Dental fluorosis: chemistry and biology. Crit Rev Oral Biol Med. 2002;13(2):155-170.

3. Amaechi BT, Higham SM, Edgar WM. Efficacy of sterilisation methods and their effect on enamel demineralization. Caries Res. 1998;32:441-6.

4. Ammari AB, Bloch-Zupan A, Ashley PF. Systematic review of studies comparing the anti-caries efficacy of children's toothpaste containing 600 ppm of fluoride or less with high fluoride toothpastes of 1,000 ppm or above. Caries Res. 2003;37(2):85-92.

5. Arends J, Christoffersen J. Nature and role of loosely bound fluoride in dental caries. J Dent Res. 1990;69(Spec Issue):601-5.

6. Arends J, Schuthof J, Jongebloed WG. Lesion depth and microhardness indentations on artificial white spot lesions. Caries Res. 1980;14:190-5.

7. Arends J, Schuthof J, Jongebloed WG. Microhardness indentations on artificial white spot lesions. Caries Res. 1979;13(5):290-7.

8. Arends J, Ten Bosch JJ. Demineralization and remineralization evaluation techniques. J Dent Res. 1992;71:924-928.

9. Argenta RMO, Tabchoury C, Cury J. A modified ph-cycling model to evaluate fluoride effect on enamel demineralization. Pesqui Odontol Bras. 2003;17(3):241-6.

10. Arnold FA, Likins RC, Russel AL, Scott DB. Fifteenth year of the Grand Rapdis fluoridation study. J Am Dent Assoc. 1962;65:780-5.

11. Ast DB, Fitzgerald B. Efectiveness of water fluoridation. J Am Dent Assoc. 1962;65:581-8.

12. Axelson P. Preventive materials, methods and programs. Chicago: Quintessence Publishing; 2004.

13. Benelli EM, et al. In situ anticariogenic potential of glass ionomer cement. Caries Res. 1993;27(4):280-4. 
14. Blake-Haskins JC, Mellberg JR, Snyder C. Effect of calcium in model plaque on the anticaries activity of fluoride in vitro. J Dent Res 1992; 71:1482-1486.

15. Blayney JR, Hill IN. Fluoride and dental caries. J Am Dent Assoc. 1967;74(Spec Issue):233-302.

16. Bloch-Zupan A. Is the fluoride concentration limit of 1,500 ppm in cosmetics (EU guideline) still up-to-date? Caries Res. 2001;35(Supplement 1):22-25.

17. Brighenti $\mathrm{FL}$, et al. In vitro evaluation of acidified toothpastes with low fluoride conten. Caries Res. 2006;40(3):239-44.

18. Brudevold F, McCann HG, Gron P. An enamel biopsy method for determination of fluoride in human teeth. Arch Oral Biol. 1968;13(8):87785.

19. Bruun C, Givskov H, Thylstrup A. Whole saliva fluoride after toothbrushing with $\mathrm{NaF}$ and MFP dentifrices with different $F$ concentrations. Caries Res. 1984;18(3):282-8.

20. Caslavska $\mathrm{V}$, et al. $\mathrm{CaF}_{2}$ in enamel biopsies 6 weeks and 18 months after fluoride treatment. Caries Res. 1991;25(1):21-6.

21. Caslavska V, Moreno EC, Brudevold F. Determination of the calcium fluoride formed from in vitro exposure of human enamel to fluoride solutions. Arch Oral Biol. 1975;20(5-6): 33-9.

22. Caldwell RC, et al. Semiquantitative studies of in vitrocaries by microhardness tests. J Dent Res. 1958;37(2):301-5.

23. Chandler NP. Preparation of dental enamel for use in intraoral cariogenicity experiments. J Dent. 1990;18(1):54-8.

24. Chow LC, Takagi S. Deposition of fluoride on tooth surfaces by a twosolution mouth rinse in vitro. Caries Res. 1991;25(6):397-401.

25. Chow LC, Takagi S, Shih S. Effect of a two-solution fluoride mouthrinse on remineralization of enamel lesions in vitro. J Dent res. 1992;71(3):4437.

26. Cury JA, et al. Biochemical composition and cariogenicity of dental plaque formed in the presence of sucrose or glucose and fructose. Caries Res. 2000;34(6):491-97. 
27. Cury JA, et al. Effect of dentifrice containing fluoride and/or baking soda on enamel demineralization/remineralization: an in situ study. Caries Res. 2001;35:106-110.

28. Cury JA, Rebello MA, Del Bel Cury AA. In situ relationship between sucrose exposure and the composition of dental plaque. Caries Res. 1997;31(5):356-60.

29. Delbem AC, Cury JA. Effect of appliacation time of APF and NaF gels on microhardness and fluoride uptake of in vitro enamel caries. Amer J Dent. 2002;15(3):169-72.

30. Duckworth RM, Morgan SN. Oral fluoride retention after use of fluoride dentifrices. Caries Res. 1991;25(2):123-9.

31. Duckworth RM, Morgan SN, Murray AM. Fluoride in saliva and plaque following use of fluoride-containing mouthwashes. J Dent Res. 1987;66(12):1730-4.

32. Duckworth RM, Stewart D. Effect of mouthwashes of variable NaF concentration but constant $\mathrm{NaF}$ content on oral fluoride retention. Caries Res. 1994;28(1):43-47.

33. Ekstrand J, Spak CJ, Vogel GL. Pharmacokinetics of fluoride in man and its clinical relevance. J Dent Res. 1990;69(Spec Issue):550-5.

34. Feagin F, Koulourides T, Pigman W. The characterization of enamel surface demineralization, remineralization, and associeted hardness changes in human and bovine material. Arch Oral Biol. 1969;14(12):140717.

35. Featherstone JD, ten Cate JM, Shariati M, Arends J. Comparison of artificial caries-like lesions by quantitative microradiography and microhardness profiles. Caries Res. 1983;17(5):385-91.

36. Featherstone JDB, Zero DT. An in situ model for simultaneous assessment of inhibition of demineralization and enhancement of remineralization. J Dent Res. 1992;71(Special Issue):804-10.

37. Fukushima R, Granjeiro JM, Taga EM, Buzalaf MAR. Cinética do flúor na saliva de adultos e crianças após o uso de dentifrício fluoretado. Rev FOB. 2000;8(1/2):45-50. 
38. Hallsworth AS, Weatherell JA, Deutsch D. Determination of subnanogram amounts of fluoride with the fluoride electrode. Analyt Chem. 1976;L8:1160-4.

39. Hamilton IR. Biochemical effects of fluoride on oral bacteria. J Dent Res. 1990;69(Spec Issue):660-7.

40. Hodge HC, Mckay $\mathrm{H}$. The microhardness of teeth. J Am Dent Assoc. 1933;20(2):227-33.

41. Ikemi T, Koulourides T. Abrasion biopsy in studies of mineral density of experimental enamel lesions. J Dent Res. 1988;67(2):508-14.

42. Itthagarun A, Wei SHY. Analysis of fluoride ion concentrations and in vitro fluoride uptake from different commercial dentifricies. Int Dent $\mathrm{J}$. 1996;46(4):357-61.

43. Iyer $\mathrm{BV}$, et al. A new abrasion procedure for studying $\mathrm{F}$ profiles in demineralized/remineralized bovine tooth enamel. Caries Res. 1983;17(4):297-303.

44. Kato K, Nakagaki H, Takami T, Tsuge S, Ando S, Robinson C. A method for determining the distribution of fluoride, calcium and phosphorus in human dental plaque and the effect of a single in vivo fluoride rinse. Arch Oral Biol. 1997;42(7):521-5.

45. Knoop F, Peters GC, Emerson WB. A sensitive pyramidal diamond tool for indentation measurements. J Res Nat Bur Stds. 1939;23:39-61.

46. Koulourides T. Summary of session II: Fluoride and the caries process. J Dent Res. 1990;69(Spec Issue):558.

47. Koulourides T, Chien MC. The ict in situ experimental model in dental research. J Dent Res. 1992;71(Special Issue):822-27.

48. Koulourides $\mathrm{T}$, et al. An intraoral model used for studies of fluoride incorporation in enamel. J Oral Pathol. 1974;3(4):185-96.

49. Lagerweij $\mathrm{M}$, ten Cate $\mathrm{J}$. Remineralisation of enamel lesions with daily applications of a high-concentration fluoride gel and a fluoridated toothpaste: an in situ study. Caries Res. 2002;36(4):270-4.

50. Larsen MJ, Pearce EIF. Saturation of human saliva with respect to calcium salts. Arch Oral Biol. 2003;48(4):317-22. 
51. Lingström $P$, et al. Effect of frequent consuption of starchy food items on enamel and dentin demineralization and on plaque $\mathrm{pH}$ in situ. J Dent Res. 1994;73(3):652-60.

52. Lobo MM, et al. Fluoride-releasing capacity and cariostatic effect provided by sealants. J Oral Sci. 2005;47(1):35-41.

53. Loesche WJ. Role of Streptococcus mutans in human dental decay. Microbiol Rev. 1986;50(4):353-80.

54. Macpherson LM, et al. Comparison of the microflora from natural and appliance-borne enamel surfaces. Caries Res. 1991;25(1):58-64.

55. Macpherson LM, et al. The effect of sucrose application and implatation of mutans streptococci on the microbial composition of three-week experimental plaque - an in situ study. J Dent Res. 1990;69(11):1706-11.

56. Macpherson LM, Macfarlane TW, Stephen KW. An intra-oral appliance study of the plaque microflora associated with early enamel demineralization. J Dent Res. 1990;69(11):1712-6.

57. Manning RH, Edgar WM. Intra-oral models for studying de- and remineralization in man: methodology and measurement. J Dent Res. 1992;71(Special Issue):895-900.

58. Martinhon CC, et al. Effect of iron on bovine enamel and on the composition of dental biofilm formed in situ. Arch Oral Biol. 2006;51(6):471-5.

59. Melbberg JR, Hill IN. Fluoride and dental caries. J Am Dent Assoc. 1990;69(Spec Issue):771-9.

60. Mellberg JR. Hard-tissue substrates for evaluation of cariogenic and anticariogenic activity in situ. J Dent Res. 1992;71(Special Issue):913-9.

61. Moura JS, et al. Ifluence os storage solution on enamel demineraization submitted to pH cycling. J Appl Oral Sci. 2004;12(3):205-8.

62. Newbrun E, Pigman W. The hardness of enamel and dentine. Aust Dent J. 1960;5(4):210-7.

63. Newbrun E, Timberlake P, Pigman W. Changes in microhardness of enamel following treatment with lactate buffer. J Dent Res. 1959;38(2):293-300. 
64. Øgaard B. $\mathrm{CaF}_{2}$ formation: cariostatic properties and factors of enhancing the effect. Caries Res. 2001;35 Suppl 1:S40-4.

65. Øgaard B, et al. Relative cariostatic effects of $\mathrm{KOH}$-soluble and $\mathrm{KOH}$ insoluble fluoride in situ. J Dent Res. 1990;69(8):1505-7.

66. O'Mullane DM. The future of water fluoridation. J Dent Res. 1990;69 (Spec Issue):756-9.

67. Ophaug $\mathrm{RH}$, et al. Acid diffusion analysis of different forms of fluoride in human dental plaque. Arch Oral Biol. 1987;32(7):459-61.

68. Paes Leme A, Dalcico R, Tabchoury C, Del Bel Cury A, Rosalen P, Cury J. In situ effect of frequent sucrose exposure on enamel demineralization and on plaque composition after APF application and $F$ dentifricie use. $\mathrm{J}$ Dent Res. 2004;83(1):71-5.

69. Pearce El. Therapeutic modifications to the mineral ion composition of dental plaque. Caries Res. 1984;18(2):103-110.

70. Pearce El, et al. The effect of sucrose application frequency and basal nutrient conditions on the calcium and phosphate content of experimental dental plaque. Caries Res. 2002;36(2):87-92.

71. Pearce El, Margolis HC, Kent Junior RL. Effect of in situ plaque mineral supplementation on the state of saturation of plaque fluid during sugarinduced acidogenesis. Eur J Oral Sci 1999; 107: 251-259.

72. Pearce El, Nelson DG. In vivo comparison of caries inhibition by plaque mineral enriching mouthrinse and a fluoride dentifrice. Caries Res 1988; 22: $362-370$.

73. Pessan JP, et al. Fluoride concentrations in dental plaque and saliva after the use of a fluoride dentifricie preceded by a calcium lactate rinse. Eur $\mathrm{J}$ Oral Sci. 2006;114:489-93.

74. Pickerill HP. The prevention of dental caries and oral sepsis. $3^{\mathrm{a} e d .}$ New York: Paul B. Hoeberondres;1924.Thylstrup A, Fejerskov O. Cariologia Clínica. $2^{a}$ ed. São Paulo: Ed. Santos; 1994.

75. Queiroz CS. Modelos de estudo in vitro para avaliar o efeito do fluoreto na desmineralização e remineralização do esmalte e dentina [tese de doutorado]. Campinas: Faculdade de Odontologia de Piracicaba. Curso de Odontologia. Departamento de Ciências Biológicas, 2004. 
76. Reintsema $\mathrm{H}$, Arends $\mathrm{J}$. An in vivo study of microhardness and fluoride uptake in partially demineralized human enamel covered by plaque. J Dent Res. 1988;67(2):471-3.

77. Rolla $\mathrm{G}$. On the role of calcium fluoride in the cariostatic mechanism of fluoride. Acta Odonto Scand. 1988;46(6):341-45.

78. Rolla G, Ekstrand J. Fluoride in oral fluids and dental plaque. In: Fejerskov O, Ekstrand J, Burt BA. Fluoride in dentistry. 2.ed. Copenhagen: Munksgaard; 1996. p. 215-29.

79. Rose RK, Dibdin GH, Shellis RP. A quantitative study of calcium binding and aggregation in selected oral bacteria. J Dent Res. 1993;72(1):78-84.

80. Rose RK, Hogg SD, Shellis RP. A quantitative study of calcium binding by isolated streptococcal cell walls and lipoteichoic acid. Comparison with whole cells. J Dent res. 1994;73(11):1742-7.

81. Rose RK, Shellis RP, Lee AR. The role of cation bridging in microbial fluoride binding. Caries Res. 1996;30(6):458-64.

82. Rose RK, Turner SJ. Fluoride-induced enhancement of duffusion in streptococcal model plaque biofilms. Caries res. 1998;32(3):227-32.

83. Rose RK, Turner SJ, Dibdin GH. Effect of $\mathrm{pH}$ and calcium concentration on calcium diffusion in streptococcal model-plaque biofilms. Arch Oral Biol. 1997;42(12):795-800.

84. Särner B, et al. Effect of fluoridated toothpicks and dental flosses on enamel and dentine and on plaque composition in situ. Caries Res. 2005;39(1):52-9.

85. Schäfer F, Raven SJ, Parr TA.The effect of lesion characteristic on remineralization and model sensitivity. J Dent Res. 1992;71 (Special Issue):911-13.

86. Scheie $\mathrm{AA}$, et al. Microbial composition, $\mathrm{pH}$-depressing capacity and acidogenicity of 3-week smooth surface plaque developed on sucroseregulated diets in man. Caries Res. 1984;18(1):74-86.

87. Shellis RP, Duckworth RM. Studies on the cariostatic mechanisms of fluoride. Int Dent J. 1994;44(Supplement 1):263-73. 
88. Shore R. Kirkham J, Devine D, Marsh P, Nattress B, Robinson C. Investigation to evaluate and validate the Leeds in situ device for the study of enamel remineralisation in vivo. J Dent. 2001;29(6):415-9.

89. Sidi AD. Effect of brushing with fluoride toothpaste on the fluoride, calcium and inorganic phosphorus concentrations in approximal plaque of young adults. Caries Res. 1989;23(4):268-71.

90. Souder W, Schoonover IC. Abrasion and solution of teeth: a sensitive, visual method for detecting these injuries. J Am Dent Assoc. 1943;30(20):1725-34.

91. Tanaka M, Margolis HC. Release of mineral ions in dental plaque following acid production. Arch Oral Biol. 1999;44(3):253-8.

92. Tatevossian A. Fluoride in dental plaque and its effects. J Dent Res. 1990;69(Special issue):645-52.

93. ten Cate JM. Current concepts on the theories of the mechanism of action of fluoride. Acta Odontol Scand. 1999 Dec;57(6):325-329.

94. ten Cate JM. Review of fluoride, with special emphasis on calcium fluoride mechanisms in caries prevention. Eur J Oral Sci. 1997;105(5 Pt 2):461-5.

95. ten Cate JM, Arends J. Remineralization of artificial enamel lesions in vitro. Caries Res. 1977;11(5):277-86.

96. ten Cate JM, Duijsters PP. The influence of fluoride in solution on tooth enamel demineralization. I. Chemical data. Caries Res. 1983;17(3):193-9.

97. ten Cate JM, Duijsters PP. The influence of fluoride in solution on tooth enamel demineralization. II. Microradiographic data. Caries Res. 1983;17(6):513-9.

98. ten Cate JM, van de Plassche-Simons YM, van Strijp AJP. Importance of model parameters in the assessment of intra-oral remineralization. J Dent Res. 1992;71(Special Issue):879-83.

99. Tenuta L, Lima J, Cardoso C, Tabchoury C, Cury J. Effect of plaque accumulation and salivary factors on enamel demineralization and plaque composition in situ. Pesqui Odontol Bras. 2003;17(4):326-31.

100. Thylstrup A, Fejerskov O. Cariologia Clínica. $2^{a}$ ed. São Paulo: Ed. Santos; 1994. 
101. van Houte J. Bacterial specificity in the etiology of dental caries. Int Dent J. 1980;30(4):305-26.

102. Vernon PG, et al. The effect of study design on in situ treatment of carious enamel lesions. J Dent Res. 1992;71(Special Issue):814-8.

103. Vieira AE, Delbem AC, Sassaki KT, Rodrigues E, Cury JA, Cunha RF. Fluoride dose response in $\mathrm{pH}$-cycling models using bovine enamel. Caries Res. 2005;39(6):514-20.

104. Vogel GL, Carey CM, Ekstrand J. Distribution of fluoride in saliva and plaque fluid after a $0.048 \mathrm{~mol} / \mathrm{L}$ NaF rinse. J Dent Res. 1992;71(9):15537.

105. Vogel GL, Chow LC, Brown WE. A microanalytical procedure for the determinations of calcium, phosphate and enamel biopsy samples. Caries Res. 1983;17(1):23-31.

106. Vogel GL, Chow G, Schumacher G, Takagi S. Salivary-F after NaF rinsing greatly increased by concentrated calcium pre-rinse. J Dent Res. 2004;83(Spec. Issue A):Abs 1332.

107. Vogel GL, et al. Changes in lactate and other ions in plaque and saliva after a fluoride rinse and subsequent sucrose administration. Caries Res. 2002;36(1):44-52.

108. Vogel GL, et al. Effect of a water rinse on "labile" fluoride and other ions in plaque and saliva before and after convencional and experimental fluoride rinses. Caries Res. 2001;35(2):116-24.

109. Vogel GL, et al. Fluoride in plaque fluid, plaque and saliva measured for 2 hours after a sodium fluoride monofluorophosphatee rinse. Caries Res. 2000;34(5):404-11.

110. Vogel $\mathrm{GL}$, et al. In vivo fluoride concentrations measured for two hours after a NaF or a novel two-solution rinse. J Dent Res. 1992;71(3):448-52.

111. Vogel GL, et al. Increased overnight fluoride concentrations in saliva, plaque and plaque fluid after a novel two-solution rinse. J Dent Res. 1997;73(3):761-7.

112. Vogel GL, Shim D, Schumacher GE, Takagi S. Plaque fluid and salivary fluoride one hour after a Ca pre-rinse/NaF rinse. Caries Res. 2005;39:316 (Abs 85). 
113. Vogel GL, Shim D, Takagi S, Schumacher GE, Chow LC. Calcium prerinse increases extractable fluoride in plaque from $\mathrm{NaF}$ rinse. $35^{\text {th }}$ Annual Meeting \& Exhibition of the AADR; March 8-11; Orlando, Florida; 2006.

114. Watson PS, Pontefract HA, Devine DA, Shore RC, Nattress BR, Kirkham $\mathrm{J}$, et al. Penetration of fluoride into natural plaque biofilms. J Dent Res. 2005;84:451-455.

115. White DJ, Featherstone JDB. A longitudinal microhardness analysis of fluoride dentifrice effects on lesion progression in vitro. Caries Res. 1987;21(6):501-12.

116. White DJ. Reactivity of fluoride dentifrices with artificial caries. 1 Effects on early lesions: F uptake, surface hardening and remineralization. Caries Res. 1987;21(2):126-40.

117. Whitford GM, Buzalaf MAR, Bijella MF, Waller JL. Plaque fluoride concentrations in a community without water fluoridation: effects of calcium and use of a fluoride or placebo dentifrice. Caries Res. 2005;39(2):100-7.

118. Whitford GM. The metabolism and toxicity of fluoride. Monographs in oral science 16. Basel: Karger; 1996.

119. Whitford GM, Wasdin JL, Schafer TE, Adair SM. Plaque fluoride concentrations after using a fluoridated or a placebo dentifrice $\mathrm{J}$ Dent Res. 2001;80 Special Issue:238 (Abstract 1618).

120. Whitford GM, Wasdin JL, Schafer TE, Adair SM. Plaque fluoride concentrations are dependent on plaque calcium concentrations. Caries Res. 2002;36(4):256-265.

121. Zero DT. Comparison of the iodide permeability test, the surface microhardness test, and mineral dissolution of bovine enamel following acid challenge. Caries Res. 1990;24(3):181-8.

122. Zero DT. In situ caries models. Adv Dent Res. 1995;9(3):214-30. 
Abstract 



\section{Abstract}

\section{Effect of calcium lactate rinse previously to the use fluoride dentifrice on bovine enamel and on the composition of the dental biofilm formed "in \\ situ"}

This in situ blind crossover study investigated the effect of calcium lactate rinse prior to the use fluoride $(F)$ dentifrice on demineralization of the sound enamel and on remineralization of the artificial enamel caries, as well as on the composition of dental biofilm. During 4 phases of 14 days each, 10 volunteers wore palatal appliances containing 4 blocks of bovine enamel $(4 \times 4 \times 2.5 \mathrm{~mm})$ : two sound enamel blocks that were subjected to the low cariogenic challenge $(\mathrm{H})$ and two other enamel blocks with artificial caries lesion (C) formed in vitro, using buffer acetate solution $\left(16,37^{\circ} \mathrm{C}\right)$. Three times a day, after the meals, the volunteers dripped a fresh $20 \% \mathrm{w} / \mathrm{v}$ sucrose solution on sound enamel, whereas on the carious enamel no treatment was performed. After five minutes, the appliance returned into the mouth and they rinsed with $10 \mathrm{~mL}$ of a $150 \mathrm{mM}$ calcium lactate or placebo solution, during 1 minute. In sequence, a solution of fluoride or placebo dentifrice (1:3 w/v) was dripped onto the both blocks. During 1 minute, the volunteers brushed your teeth with $0,3 \mathrm{~g}$ of respective dentifrice. After that the time elapsed, the appliance returned into the mouth and they rinsed the mouth with $10 \mathrm{~mL}$ of water $(0.7 \mathrm{ppm} \mathrm{F})$. The enamel alterations were evaluated by the percentage of surface microhardness change (\%SMHC), longitudinal microhardness (\% min. vol.) and alkali-soluble $\mathrm{F}$ analysis. The dental biofilm formed on the blocks was collected and analysed for $\mathrm{F}$ and $\mathrm{Ca}$. Data were analysed by ANOVA $(p<0.05)$. The Ca pre-rinse before the use of the $\mathrm{F}$ dentifrice produced a significant increase in biofilm $\mathrm{F}$ concentrations and in the remineralization of artificial enamel caries, in comparison to fluoride dentifrice alone. However, the $\mathrm{Ca}$ pre-rinse did not reduce enamel demineralization.

Keywords: Dental caries; Dental biofilm; Demineralization; Calcium, Fluoride dentifrice. 
